\title{
Stress Corrosion Cracking Tests on High-Level-Waste Container Materials in Simulated Tuff Repository Environments
}

NUREG/CR--4619

TI86 013148

Prepared by T. Abraham, H. Jain, P. Soo

Brookhaven National Laboratory

Prepared for

U.S. Nuclear Regulatory

Commission 


\section{DISCLAIMER}

This report was prepared as an account of work sponsored by an agency of the United States Government. Neither the United States Government nor any agency thereof, nor any of their employees, make any warranty, express or implied, or assumes any legal liability or responsibility for the accuracy, completeness, or usefulness of any information, apparatus, product, or process disclosed, or represents that its use would not infringe privately owned rights. Reference herein to any specific commercial product, process, or service by trade name, trademark, manufacturer, or otherwise does not necessarily constitute or imply its endorsement, recommendation, or favoring by the United States Government or any agency thereof. The views and opinions of authors expressed herein do not necessarily state or reflect those of the United States Government or any agency thereof. 


\section{DISCLAIMER}

Portions of this document may be illegible in electronic image products. Images are produced from the best available original document. 


\begin{abstract}
Types 304L, 316L and 321 austenitic stainless steel and Incoloy 825 are being considered as candidate container materials for emplacing high level waste in a tuff repository. The stress corrosion cracking susceptibility of these materials under simulated tuff repository conditions was evaluated by using the notched c-ring method. The tests were conducted in boiling synthetic groundwater as well as in the steam/air phase above the boiling solutions. All specimens were in contact with crushed Topopah Spring tuff. The investigation showed that microcracks are frequently observed after testing as a result of stress corrosion cracking or intergranular attack. Results showing changes in water chemistry during test are also presented.
\end{abstract}


CONTENTS

$\underline{\text { Page }}$

ABSTRACT. . . . . . . . . . . . . . . . . . . . iii

FIGURES . . . . . . . . . . . . . . . ......... . vii

TABLES. . . . . . . . . . . . . . . . . . . . . . xiii

ACKNOWLEDGMENT. • • . . . . . . . . . . . . . . . . . . . xv

EXECUTIVE SUMMARY . . . . . . . . . . . . . . . . . . xvii

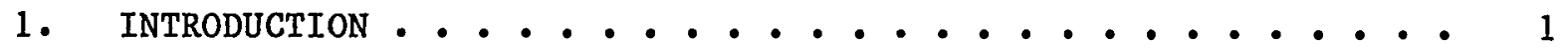

2. SURVEY OF STRESS-CORROSION BEHAVIOR OF PROPOSED CONTAINER

MATERIALS. . . . . . . . . . . . . . . . . . . . 2

3. GEOCHEMICAL CONDITIONS IN A TUFF REPOSITORY. . . . . . . . 17

4. EXPERIMENTAL METHOD. . . . . . . . . . . . . 18

4.1 Test Plan ....................... 18

4.2 Materials and Specimen Preparation. . . . . . . 18

4.2.1 C-Ring Specimens ............. 18

4.2.2 Tuff ...................... 25

4.2.3 Preparation of Synthetic Groundwater . . . . . . 27

4.3 Apparatus . . . . . . . . . . . . . . 28

4.4 Test Procedure. . . . . . . . . . . . . . . . 29

4.5 0xygen Measurements in the Steam Phase and in the Solution. 31

5. C-RING TEST RESULTS. . . . . . . . . . . . . 33

5.1 Type 304L Stainless Steel .............. 33

5.2 Type 316L Stainless Steel . . . . . . . . . . 39

5.3 Type 321 stainless steel. . . . . . . . . . . 48

5.4 Incoloy 825 . . . . . . . . . . . . . 52

5.5 Salt Deposition During Test . . . . . . . . . 54

6. WATER CHEMISTRY MEASUREMENTS . . . . . . . . . . . . 58

7. DISCUSSION AND CONCLUSIONS . . . . . . . . . . . . 66

8. SUMMARY. . . . . . . . . ............. . 67

9. REFERENCES ........................ 69 


\section{FIGURES}

Page

Figure 1 Proposed relationship between chloride and oxygen content of alkaline phosphate treated boiler water and susceptibility to stress corrosion cracking of austentic stainless steel exposed to the steam phase with intermittent wetting ............ 4

Figure 2 The relationship between original strain in bentbeam specimen and time-to-crack for (a) Type 321 stainless steel at $300^{\circ} \mathrm{C}$ and (b) Type 304 stainless steel at $200^{\circ} \mathrm{C}$. . . . . . . . . . . . . 6

Figure 3(a) Schematic diagram of double U-bend type specimen. . . . 7

Figure 3(b) Schematic diagram of gamma-ray irradiation (first test)........................ 7

Figure 4 Microstructure of cracks. . . . . . . . . . 8

Figure 5 Time-temperature-sensitization curve for Type 316ELC

for tests conducted in pure water at $250^{\circ} \mathrm{C}$. . . . . . 9

Figure 6 Effect of carbon on SCC of Type 316SS in high temperature pure water at $250^{\circ} \mathrm{C}$. . . . . . . . 9

Figure $7 \quad$ Comparison of SCC susceptibility on several representative austenitic stainless steels sensitized at $620^{\circ} \mathrm{C}$ for 24 hours. . . . . . . . 11

Figure $8 \quad$ Effect of chloride added as $\mathrm{NaCl}$ on cracking of Type 304 stainless steel at $100^{\circ} \mathrm{C}$. Solution transported by porous material to specimen. . . . . . 12

Figure 9 Percentage of specimens unbroken plotted against exposure time for various commercial alloys exposed to a boiling magnesium chloride solution at $154^{\circ} \mathrm{C}$. Specimens stressed to $90 \%$ of the yield stress . . . . . 14

Figure 10 Microstructure of Type 304L stainless steel. (a) Asrecelved, etched in glyceregia. (b) Sensitized at $600^{\circ} \mathrm{C}$ for 100 hours, etched in oxalic acid. . . . . . . . 21

Figure $11 \quad$ C-ring specimen design. . . . . . . . . . . 22 
FIGURES (continued)

$\underline{\text { Page }}$

Figure 12 Load vs deflection of Type 304L stainless steel

sensitized C-ring test specimen under stress . . . . . 23

Figure 13 Load vs in-situ strain at the apex of a Type 316L

stainless steel C-ring specimen. . . . . . . . 24

Figure $14 \quad$ C-ring stress corrosion cracking test apparatus. . . . . 29

Figure 15 Schematic of the specimen arrangement in a

test vesel ............... . 30

Figure 16 An SEM micrograph of part of. the outer diameter of -

an as-received (solution annealed) Type 304L stainless

steel specimen tested in steam/air phase above

boiling J-13 groundwater for 3 months (x2000). . . . 35

Figure 17 An SEM micrograph of part of the outer diameter

of a sensitized Type 304L stainless steel specimen

tested in steam/air phase above boiling $10 \times \mathrm{J}-13$

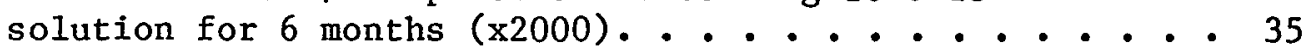

Figure 18 An SEM micrograph of part of the outer diameter

of an as-received (solution annealed) Type 304L

stainless steel specimen tested in boiling

$10 \mathrm{xJ}-13$ solution for $\operatorname{six}$ months $(\mathrm{x} 2000) . . . . . .36$

Figure 19 An SEM micrograph of part of the notch root of a

sensitized Type 304L stainless steel specimen

tested in boiling $10 x J-13$ solution for six

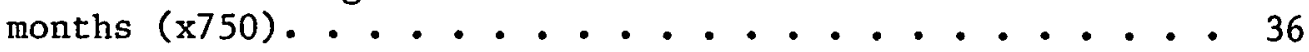

Figure 20 An SEM micrograph of part of the outer diameter of an as-received (solution annealed) Type 304L stainless steel specimen tested in boiling $\mathrm{J}-13$

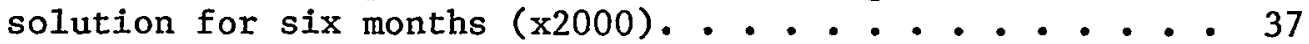

Figure 21 An SEM micrograph of part of the outer diameter of an as-received (solution annealed) Type 304L stainless steel specimen tested in boiling J-13 solution for twelve months $(\mathrm{x} 3000)$. . . . . . . 38

Figure 22 An SEM micrograph of part of the outer diamter of a sensitized Type 304L stainless steel specimen tested in steam/air phase above boiling $10 \times \mathrm{J}-13$ solution for twelve months $(\mathrm{x} 2000)$.......... 38 
Figure 23 An SEM micrograph of part of the outer diameter of an as-received, untested Type 316L stainless steel specimen (xl000). . . . . . 39

Figure 24 An SEM micrograph of part of the outer diameter of an as-received (solution annealed) Type 316L stainless steel specimen tested in boiling $\mathrm{J}-13$ water for three months $(\mathrm{x} 2000) . . . . .40$

Figure 25 An SEM micrograph of part of the outer diameter of a sensitized Type 316L stainless steel specimen tested in steam/air phase above boiling $10 \mathrm{xJ}-13$ water for three months $(\mathrm{x} 2000)$....... 41

F1gure 26 An SEM micrograph of part of the notch root of an as-received (solution annealed) Type 316L stainless steel specimen tested in boiling $\mathrm{J}-13$ water for six months (x2000).............. 42

Figure 27 An SEM micrograph of part of the outer diameter of an as-received (solution annealed) Type 316L stainless steel specimen tested in boiling $\mathrm{J}-13$

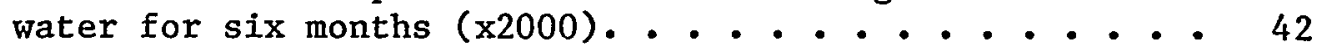

Figure 28 An SEM micrograph of part of the notch root of a sensitized Type 316L stainless steel specimen tested in boiling J-13 water for six months (x2000) ..

Figure 29 An SEM micrograph of part of the notch root of a sensitized Type 316L stainless steel specimen tested in the steam/air phase above boiling $\mathrm{J}-13$ water for six months $(x 1000) . . . . . . . . . .444$

Figure 30 An SEM micrograph of part of the notch root of an as-received (solution annealed) Type 316L stainless steel specimen tested in boiling $10 \times \mathrm{J}-13$ solution for six months (x2000)............. 44

Figure 31 A SEM micrograph of part of the notch root of an as-received (solution annealed) Type $316 \mathrm{~L}$ stainless steel specimen tested in boiling $10 \mathrm{xJ}-13$ solution

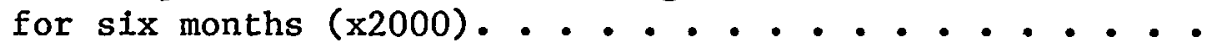

FIgure 32 A SEM micrograph of part of the notch root of a sensitized Type $316 \mathrm{~L}$ stainless steel tested in boiling 10xJ-13 solution for six months (x3000) .... 
Figure 33 An SEM micrograph of part of the outer diameter of an as-received (solution annealed) Type 316L stainless steel tested in boiling $\mathrm{J}-13$ water for twelve months $(\mathrm{x} 2000) . . . . . . . . .$.

Figure 34 An SEM micrograph of part of the outer diameter of an as-received (solution annealed) Type 316L stainless steel tested in boiling $\mathrm{J}-13$ water for twelve months $(x 2000) . . . . . . . . . .$.

Figure 35 An SEM micrograph of part of the outer diameter of an as-received (solution annealed) Type 316L stainless steel tested in steam/air phase above boiling $10 x J-13$ solution for twelve months $(x 2000)$..

Figure 36 An SEM micrograph of part of the outer diameter of an as-received (solution annealed) Type 321 stainless steel tested in steam/air phase above bolling $10 \mathrm{xJ}-13$ water for six months $(\mathrm{x} 2000) . .$. .

Figure 37 An SEM micrograph of part of the outer diameter of an as-received (solution annealed) Type 321 stainless steel specimen tested in boiling $10 \mathrm{xJ}-13$ solution for six months $(\mathrm{x} 100)$. $\mathrm{x}$-ray line profiles for $\mathrm{Fe}, \mathrm{Cr}$, and $\mathrm{O}$ are shown. . . . . 51

Figure 38 An SEM micrograph of part of the outer diameter of a sensitized Type 321 stainless steel specimen tested in boiling $10 \times J-13$ solution for one year

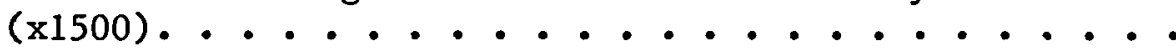

Figure 39 An SEM micrograph of part of the notch root of an as.-received (solution annealed) Incoloy 825 specimen tested in steam/air phase above boiling $10 \mathrm{xJ}-13$ water for six months $(x 700) . . . . . . . . .$.

Figure 40 An SEM micrograph of part of the notch root of an as-received (solution annealed) Incoloy 825 specimen tested in steam/air phase above boiling $10 \mathrm{xJ}-13$ water for six months $(x 2000)$. X-ray line profiles for $0, \mathrm{Cr}, \mathrm{Ni}$ and $\mathrm{Fe}$ are shown .......... 55

Figure 4la An EDAX analysis of the crack tip shown in Figure 40 . 56

Figure 4lb An EDAX analysis of the specimen matrix material shown in Figure $40 \ldots . . . . . . . .$. 
FIGURES (continued)

$\underline{\text { Page }}$

Figure 4lc An EDAX analysis of the mounting material shown in

Figure 40... . . . . . . . . . . . .

Figure 42 An SEM micrograph of the surface of a sensitized Type 304L stainless steel specimen showing black spots. The specimen was exposed to $\mathrm{J}-13$ groundwater for three months $(\times 1000)$..........

Figure 43 Optical micrograph of the surface of a sensitized Type 316L stainless steel specimen tested in $10 \mathrm{xJ}-13$ water for three months. The dark circle shows the area from where a salt layer has been removed mechanically. The boundary inside the circle corresponds to the area where a deposit predominantly containing Si, Ca, Al was present (x500)..

Figure 44 An SEM micrograph of the white compound found on the inside of the lid of the test vessel (xl000) . . . 60

Figure 45 Concentration changes in J-13 water during reaction with crushed tuff at $100^{\circ} \mathrm{C}$. . . . . . . . . .

Figure 46 Concentration changes in $10 \mathrm{xJ}-13$ water during reaction with crushed tuff at $100^{\circ} \mathrm{C}$......... 
Table 1 Candidate metals for overpacks . . . . . . . . 3

Table 2 SCC test in boiling deionized water (first test). (Dose rate: $1.1 \times 10^{5} \mathrm{R} / \mathrm{h}_{\text {.) }}$........... 5

Table 3 Chemical composition of 316ELC specimen used (wt\%) - • 8

Table 4 Chemical composition of steels used for SCC testing. . . 10

Table 5 Slow-strain-rate test results for 304L stainless steel in $150^{\circ} \mathrm{C}$ tuff-conditioned $\mathrm{J}-13$ water . . . . 13

Table 6 Stress corrosion cracking test results from U-bend specimens exposed to irradiated $\mathrm{J}-13$ water, crushed tuff rock, and water vapor. Results after 3 months exposure ................. . . 15

Table 7 Status of stress corrosion cracking test results for four-point load, bent-beam specimens exposed to $\mathrm{J}-13$ water and steam and stressed to $90 \%$ yield stress . . .

Table 8 Reference groundwater composition for tuff repositories (based on composition of water in Jackass Flats Well J-13 at the Nevada Test Site).............

Table 9 Test matrix for stress corrosion of candidate stainless

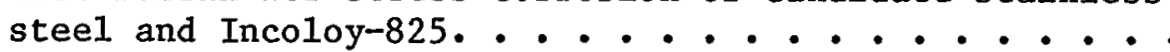

Table 10 Vendor supplied chemical analysis of test alloys (weight percent)................ 19

Table 11 Mechanical properties of as-received test alloys (vendor supplied data) ............. . 20

Table 12 Stress-strain properties of eight alloys as obtained from Instron machine tests on smooth C-ring specimens. .

Table 13 Geochemical analysis of Topopah Spring tuff (values in $\mathrm{ppm}$ unless percent is specified). . . . . . . . .

Table 14 Amount of chemical compounds used in preparing 20 liters of synthetic $\mathrm{J}-13$ water $(\mathrm{mg}) . . . . . . . .$. 
TABLES (continued)

Page

Table 15 Stress corrosion cracking tests for Type 304L

stainless steel ................ 34

Table 16 Stress corrosion cracking tests for Type 316L

stainless steel .............. . 47

Table 17 Stress corrosion cracking tests for Type 321

stainless steel ............... . 4 49

Table 18 Stress corrosion cracking tests for Incoloy 825 . . . 53

Table 19 Composition of $\mathrm{J}-13$ and $10 \mathrm{xJ}-13$ solution during stress corrosion experiments............. 61

Table 20 Chemical composition of test solutions at the end of corrosion tests $(\mu \mathrm{g} / \mathrm{mL})$ (undiluted and filtered solution)...................... 63 
The authors greatly acknowledge the efforts of $C$. Anderson in setting up the test vessels and monitoring the corrosion work. R.L. Sabatini, A. Cendrowski and $C$. Anderson carried out the optical and scanning electron microscopy, and $c$. Backsmith was responsible for the water chemistry analyses in this program. We thank the National Association of Corrosion Engineers for permission to reproduce Figures $1,2,4,5,6,7$, and 9 , and Tables 3 and 4 . A. Spira carried out the typing and preparation of the manuscript. 



\section{EXECUTIVE SUMMARY}

The stress corrosion cracking susceptibiity of Types 304L, 316L, and 321 stainless steels, and Incoloy 825 was investigated under simulated tuff repository conditions. Triplicate $\mathrm{V}$-notched C-ring specimens of these alloys were exposed to both boiling synthetic $\mathrm{J}-13$ and ten-times-concentrated $\mathrm{J}-13$ waters and, also, to the steam/air phase above these boiling solutions. All specimens were in contact with crushed tuff. The test durations were 3 , 6, and 12 months. Specimens were tested in the as-received (solution annealed) condition or after a sensitizing treatment.

The investigations show that a significant number of solution annealed as we11 as sensitized Type 304L, 316L, and 321 austenitic stainless steel samples showed stress corrosion cracking and/or intergranular attack. On the other hand, only one out of twelve specimens of Incoloy 825 examined was found to have cracked. Therefore, this material was judged to be superior.

No marked difference in stress corrosion cracking behavior could be observed between as-received and sensitized specimens. There was also no trend in the nature of the microcracks, i.e., intergranular vs. transgranular, and no obvious trend in material cracking behavior between the air/steam and water phases. The effect of exposure time on crack depth could not be accurately determined due to limited scanning electron microscopy on tested specimens.

Most of the microcracks appeared on surfaces of the tested specimens away from the notch; some of these were intergranular. More notch-root crack initlations were observed in Type 316L stainless steel compared to the other materials tested. Some cracks seem to initiate on slip planes in cold-worked material at the notch.

Major changes in water chemistry occurred within the first three months and concentrations of the various ions in the starting solutions increased many fold in the final test solutions; in some cases as much as one hundred times. Also, the water chemistries at the conclusion of tests for the starting $J-13$ and ten-times-concentrated $J-13$ solutions were similar. Clearly, the difference in concentrations of starting solutions became unimportant due to the leaching of constituents from the tuff.

Oxygen analyses of the test solutions, as well as the steam/air phase above the boiling solutions, showed that there was oxygen consumption in the test vessel either by metal corrosion or some form of interaction with the tuff. 
Based on the short-term, relatively low-temperature studies carried out in this program, and similar results published in the open literature, we believe that there is a strong potential for stress-corrosion cracking and intergranular attack on austenitic stainless steels exposed to tuff repository environments. In a repository, very long term exposure to gamma radiolysis effects, chloride-concentration mechanisms, and temperatures up to approximately $300^{\circ} \mathrm{C}$, can only be expected to exacerbate the widely-recognized susceptibility of austenitic stainless steels to cracking in chloride/oxygen/ water(steam) environments. 
1:. INTRODUCTION

The Nevada Nuclear Waste Storage Investigations (NNWSI) project is designing a waste package for the disposal of high level nuclear waste in a tuff repository. One of the reasons for considering the emplacement of waste in the tuff unsaturated zone at the Nevada Test Site is the greatly decreased amounts of water that would be present in the vicinity of the waste package. This was considered highly desirable since container corrosion and waste leaching should be reduced.

The container will be exposed to boiling groundwater or superheated steam depending on the time period after package emplacement. For the satisfactory performance of a waste package, it is expected that the container will remain unbreached by corrosion for 300 to 1000 years to allow fission products in the waste to decay to low concentrations.

From a literature survey, Russell and others (1984) assessed the likely performance of 17 candidate container materials (Table 1) using corrosion resistance, mechanical properties, weldability, and cost, as equally-weighted selection criteria. The reference material was stated to be Type 304L stainless steel with Type 316L, Type 321, and Incoloy 825 as alternates. The applicability of the selection criteria used by these authors to a repository situation is questionable since corrosion resistance is much more important with respect to containing the waste than, for example, mechanical strength or cost. There is also evidence in the literature that some of the alloys being considered by NNWSI are susceptible to stress corrosion cracking (SCC) in steam and in water environments very similar to those expected in a tuff repository. Below is given a brief literature survey of the stress corrosion behavior of the proposed container materials in environments which are similar or extrapolatable to tuff repository conditions. It shows that there is a very strong potential for stress corrosion cracking and an experimental verlfication would be highly desirable. On this basis a detailed testing program was initiated at BNL to check the integrity of the NNWSI reference materials. 
Much of the available data in the literature is focused on stainless steels in the "sensitized" condition in which high-temperature processes, such as welding, cause the precipitation of interconnected chromium-rich carbides at the grain boundaries. Areas adjacent to these carbides are depleted in chromium and they become especially susceptible to rapid corrosion in aqueous environments containing chloride ion and oxygen. The literature review given below is directed at this type of environment.

Figure 1 shows that austenitic stainless steels exposed to the steam phase of alkaline-phosphate-treated boiler water, and given intermittent wetting cycles, will fail by stress-corrosion cracking even though the water contains very low $\mathrm{Cl}^{-} / \mathrm{O}_{2}$ levels (Williams, W.L., 1957). For example, $5 \mathrm{ppm} \mathrm{O}_{2}$ and $5 \mathrm{ppm} \mathrm{Cl}^{-}$in the boiler water will cause failure of stainless steels exposed to the steam phase.

Data in Figure 2 show results from bent-beam tests on Type 304 and 321 stainless steels. Strained samples were maintained at $200^{\circ}$ and $300^{\circ} \mathrm{C}$ in the steam phase above water containing $5 \mathrm{ppm} \mathrm{Cl}^{-}$. For strains as low as $10^{-3}$ $\mathrm{cm} / \mathrm{cm}$ failure readily occurs in times of 40-100 hours (Birchon, D., 1964).

Data from Japan (JAERI-M-82-145, 1983; Furuya, T. and others, 1984) on a range of stainless steels and high nickel alloys in boiling deionized water also show that even these "benign" conditions can cause failure. The test apparatus is shown in Figure 3. Double-U-bend samples were used, some containing $V$ notches at the specimen apexes to give stress concentration effects. Table 2 shows that Type 304 and Type 304L display stress corrosion cracking behavior without irradiation and also under a gamma dose rate of 1.1 $x 10^{5} \mathrm{R} / \mathrm{h}$. Usually, cracking occurs on the inner $U$-bend specimens, but it also occurs on the outer specimens which have $V$ notches. Irradiated solutions are more damaging than non-irradiated ones, probably because of the generation of oxidizing species.

The observation that cracking is more likely on the inner U-bend samples is probably connected with crevice-type conditions in which small volumes of trapped water can alter their composition and $\mathrm{Eh} / \mathrm{pH}$ conditions more rapidly than those exposed to large amounts of free solution. Crushed tuff packing adjacent to the HLW container will likely give such crevice-like conditions.

Kowaka and others (1978) studied the stress corrosion cracking behavior of austenitic stainless steel with extra low carbon (carbon content less than $0.02 \%$, termed $316 \mathrm{ELC}$ ) as an alternate material to replace Type 304 for BWR piping. The composition of the steel are given in Table 3. Double U-bend sensitized specimens of Types $304,316,316 \mathrm{~L}$, and $316 \mathrm{ELC}$ were tested in nondeaerated pure water at $250^{\circ} \mathrm{C}$ for 500 hours. Figure 4 shows that Type 316 ELC SS has superior SCC resistance since only small pits are seen on these specimens. 
Table 1 Candidate metals for overpacks. (Russel1 and others, 1984).

\begin{tabular}{|c|c|c|}
\hline \multicolumn{2}{|c|}{$\begin{array}{l}\text { Commercial material } \\
\text { designation }\end{array}$} & Chemical composition (wt $)$ \\
\hline 1. & $\begin{array}{l}\text { AISI } 1020 \mathrm{cs} \\
\text { (UNS G10200) }\end{array}$ & c .18-.23, Mn .3-.6, P. $.04 \max , 5.05 \max$ \\
\hline 2. & ASTM A537B CS & $\begin{array}{l}\text { C .24 max, Mn } .7-1.35, \mathrm{P} .035 \max , \mathrm{S} .04 \max , \\
\mathrm{Si} .15-.5, \mathrm{Cr} .25 \mathrm{max}, \mathrm{Ni} .25 \mathrm{max}, \mathrm{Mo} .08 \mathrm{max}, \\
\text { Cu .35 max }\end{array}$ \\
\hline 3. & $\begin{array}{l}\text { AISI } 409 \text { ss } \\
\text { (UNS } 540900 \text { ) }\end{array}$ & $\begin{array}{l}\text { C .08 max, Cr 10.5-11.75, Mn } 1.0 \max , \mathrm{Ni} 0.50 \max , \\
P .04 \max , \mathrm{S} .045 \max , \mathrm{Si} 1.0 \max , \mathrm{Ti} 6 \mathrm{XC} \min \\
-0.75 \max \end{array}$ \\
\hline & $\begin{array}{l}26 \mathrm{Cr}-1 \text { Mo ss } \\
\text { (UNS S44626) }\end{array}$ & $\begin{array}{l}\mathrm{C} .06 \mathrm{max}, \mathrm{Cr} 25 .-27, . \mathrm{Cu} .2 \mathrm{max}, \mathrm{Mn} .4 \mathrm{max}, \\
\text { Mo } .75-1.50, \mathrm{~N} .04 \mathrm{max}, \mathrm{Ni} .05 \mathrm{max}, \mathrm{P} .04 \mathrm{max}, \\
\mathrm{S} .02 \mathrm{max}, \mathrm{Si} .75 \mathrm{max}, \mathrm{Ti} 0.20-1.00, \text { other } \mathrm{Ti} 7 \mathrm{X} \\
(\mathrm{C}+\mathrm{N}) \mathrm{min}\end{array}$ \\
\hline & $\begin{array}{l}\text { AISI } 304 \mathrm{~L} \text { ss } \\
\text { (UNS S30403) }\end{array}$ & $\begin{array}{l}\text { C } 0.030 \max , \text { Cr } 18.00-20.00, \text { Mn } 2.00 \max , \mathrm{Ni} \\
8.00-12.00, \mathrm{P} 0.045 \max , \mathrm{S} 0.030 \mathrm{max}, \mathrm{Si} 1.00 \max \end{array}$ \\
\hline & $\begin{array}{l}\text { AISI } 321 \text { ss } \\
\text { (UNS } 532100 \text { ) }\end{array}$ & $\begin{array}{l}\text { C } 0.08 \max , \text { Cr } 17.00-19.00, M n 2.00 \max , \mathrm{Ni} \\
9.00-12.00, \mathrm{P} 0.045 \max , \mathrm{S} 0.030 \mathrm{max}, \mathrm{Si} 1.00 \mathrm{max} \text {, } \\
\text { Ti } 5 x \mathrm{c} \text { min }\end{array}$ \\
\hline 7. & $\begin{array}{l}\text { AISI } 316 L \text { ss } \\
\text { (UNS S31603) }\end{array}$ & $\begin{array}{l}\text { C } 0.030 \max , \mathrm{Cr} 16.00-18.00 \text {, Mn } 2.00 \max \text {, } \\
\text { Mo } 2.00-3.00, \mathrm{Ni} 10.00-14.00, \text { P } 0.045 \mathrm{max} \text {, } \\
\mathrm{S} 0.030 \mathrm{max}, \mathrm{Si} 1.00 \mathrm{max}\end{array}$ \\
\hline & $\begin{array}{l}\text { AISI } 317 \text { ss } \\
\text { (UNS } 531703 \text { ) }\end{array}$ & 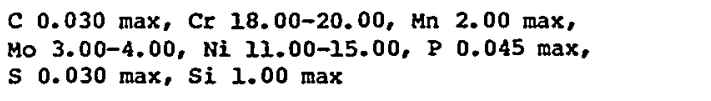 \\
\hline 9. & $\begin{array}{l}\text { Nitronic } 33 \text { ss } \\
\text { (UNS } 524000 \text { ) }\end{array}$ & $\begin{array}{l}\text { C } 0.08 \text { max, Cr } 17.00-19.00, \text { Mn } 11.50-14.50 \text {, } \\
\text { N } 0.02-0.40, \mathrm{Ni} 2.50-3.75, \text { P } 0.060 \max , \\
\mathrm{s} 0.030 \mathrm{max}, \mathrm{Si} 1.00 \mathrm{max}\end{array}$ \\
\hline 10. & $\begin{array}{l}\text { JS } 700 \text { ss } \\
\text { (UNS N08700) }\end{array}$ & 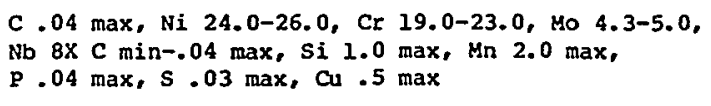 \\
\hline 11. & $\begin{array}{l}\text { Ferralium } 255 \text { ss } \\
\text { (UNS S32550) }\end{array}$ & $\begin{array}{l}\mathrm{C} .04 \mathrm{max}, \mathrm{Cr} 24.0-27.0, \mathrm{Mo} 2.0-4.0 \text {, Ni } 4.5-6.5 \text {, } \\
\mathrm{Si} 1.0 \mathrm{max}, \mathrm{Mn} 1.5 \mathrm{max}, \mathrm{N} .10-.25, \text { Cu } 1.5-2.5\end{array}$ \\
\hline 12. & $\begin{array}{l}\text { Incoloy } 825 \\
\text { (UNS N08825) }\end{array}$ & $\begin{array}{l}\text { AI } 0.2 \max , c 0.05 \max , C r 19.5-23.5, \text { cu } 1.5-3.0 \text {, } \\
\text { Fe bal, Mn } 1.0 \text { max, Mo } 2.5-3.5 \text {, Ni } 38.0-46.0, \\
S 0.03 \max , S i 0.5 \max , T i 0.6-1.2\end{array}$ \\
\hline 13. & $\begin{array}{l}\text { Inconel } 625 \\
\text { (UNS N06625) }\end{array}$ & 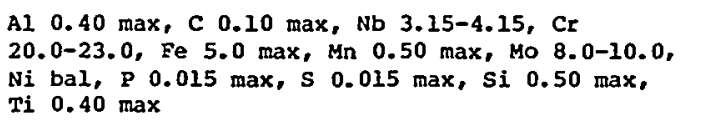 \\
\hline 14. & $\begin{array}{l}\text { Ti Grade } 2 \\
\text { (UNS R50400) }\end{array}$ & $\begin{array}{l}\text { C } 0.10 \text { max, H } 0.015 \max , \text { Fe } 0.30 \text { max, N } 0.03 \text { max, } \\
\text { O } 0.25 \text { max, Ti Rem }\end{array}$ \\
\hline 15. & Ti Grade 12 & 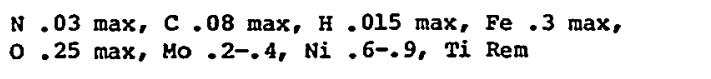 \\
\hline 16. & $\begin{array}{l}\text { 2r } 702 \\
\text { (UNS R60702) }\end{array}$ & $\begin{array}{l}\text { C } 0.05 \mathrm{max}, \mathrm{H} 0.005 \mathrm{max}, \text { He } 4.5 \mathrm{max}, \mathrm{N} 0.025 \mathrm{max} \text {, } \\
\text { Other } 2 r+\text { Hf } 99.2 \mathrm{~min}, \mathrm{Fe}+\mathrm{Cr} 0.2 \mathrm{max}\end{array}$ \\
\hline 17. & $\begin{array}{l}\text { Cupronickel } 70 / 30 \\
\text { (UNS C71590) }\end{array}$ & Cu 67.0 min, Ni 29.0-33.0, +... \\
\hline
\end{tabular}




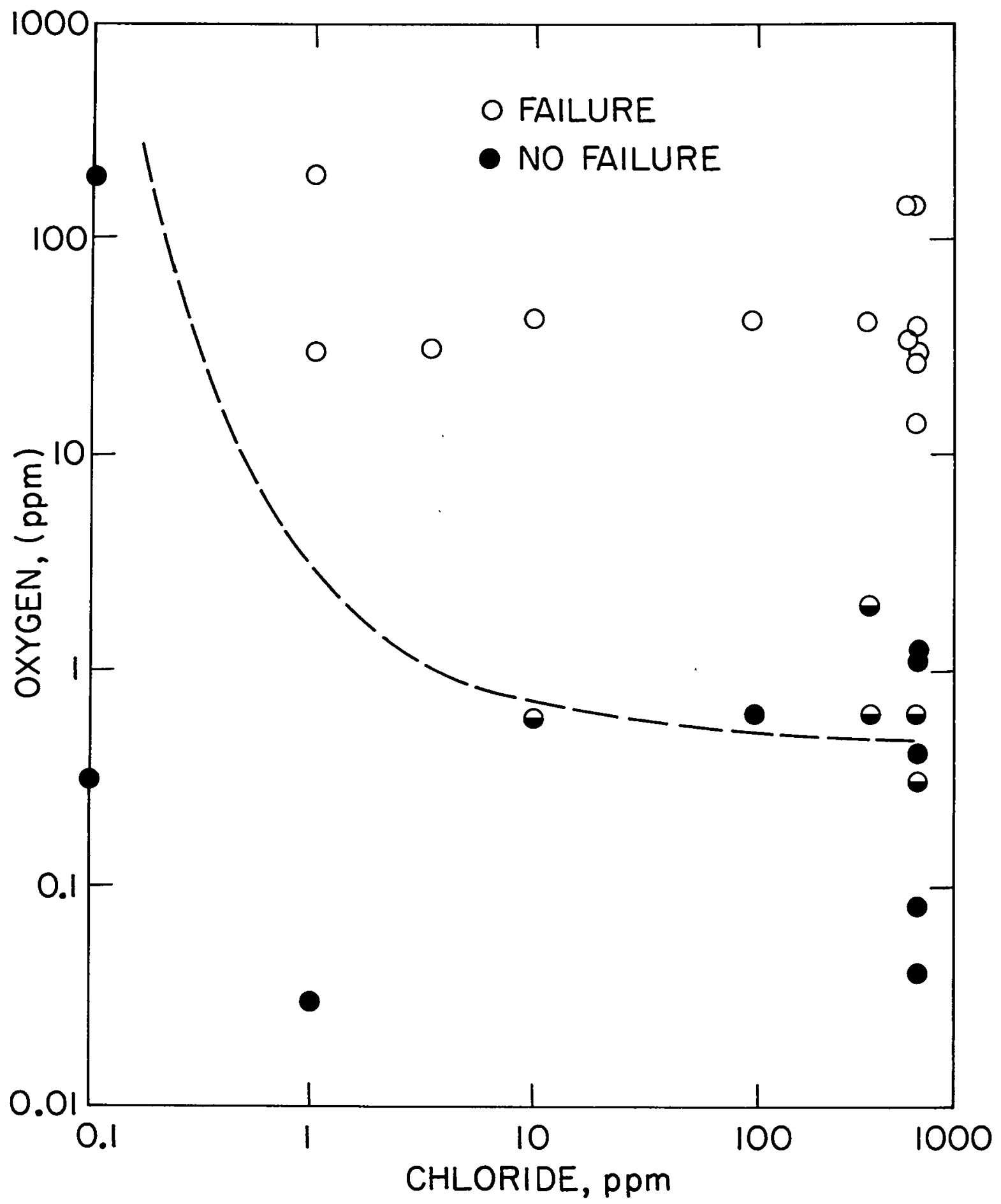

Figure 1 Proposed relationship between chloride and oxygen content of alkaline phosphate treated boiler water and susceptibility to stress corrosion cracking of austenitic stainless steel exposed to the steam phase with intermittent wetting (Williams, W.L., 1957). 
Table 2 SCC test in boiling deionized water (first test). Dose rate: $1.1 \times 10^{5} \mathrm{R} / \mathrm{h}$. (JAERI-M-82-145, 1983).

\begin{tabular}{|c|c|c|c|c|c|c|c|c|}
\hline \multirow{3}{*}{ A110y } & \multirow{3}{*}{$\begin{array}{l}7 x \\
(A m y)\end{array}$} & I-ray & \multicolumn{3}{|c|}{ irredietion } & \multicolumn{3}{|c|}{ irredzation } \\
\hline & & \multirow{2}{*}{$\begin{array}{l}\text { Totel } \\
\text { dose } \\
\text { (R) }\end{array}$} & \multicolumn{3}{|c|}{ Max. depth of SCC ( am ) } & \multicolumn{3}{|c|}{ Max. depth of ScC $(\mathrm{mm})$} \\
\hline & & & Plain & \multicolumn{2}{|c|}{$v$-notched } & Plasn & \multicolumn{2}{|c|}{$v$-notened } \\
\hline \multirow{6}{*}{ npe $304=$} & 7 & $20 \times 10^{7}$ & $1.50 ? 0.70$ & 120 & . 1.00 & 1.30 . 0.60 & 31.50 & . 1.30 \\
\hline & 14 & $10 \times 10^{7}$ & 220.220 & 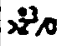 & .220 & $2200 \cdot 220$ & x.s. & .21 .50 \\
\hline & 30 & $2 \times x^{7}$ & 2210,200 & 220 & - 220 & $220 \cdot .220$ & 220 & . 220 \\
\hline & $\infty$ & $27=20^{2}$ & 220,220 & 2000 & - $22 \operatorname{sis}^{2}$ & 220,220 & 220 & - 220 \\
\hline & 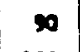 & $26 \times 10^{4}$ & $2210, \quad 220$ & 220315 & 5. 220 & $220 \cdot 220$ & r.ssis & 5. 21.sosis \\
\hline & 200 & $2.2 \times 10^{8}$ & $220,22,0$ & 2231. & 5. $22 \wedge 1.5$ & $220 \cdot 220$ & stsphs & 3. s1.sos \\
\hline \multirow[t]{3}{*}{ Type 3040} & 100 & $2.2 \times 10^{\prime \prime}$ & 220,220 & 2202.5 & 5. $22 \mathrm{sis}$ & 220,220 & xhspis & 3. 31.50 \\
\hline & 7 & $20 \times 10^{7}$ & $0,0, \infty 0$ & $\infty$ & . 0,0 & $\infty 0 . \infty 0$ & $\infty$ & - $\infty$ \\
\hline & 14 & $40 \times 10^{7}$ & 00. & $\infty$ & - 0,0 & $\infty . \infty$ & $\infty$ & - $\infty$ \\
\hline \multirow[t]{4}{*}{ now sore } & 30 & $46 \times 10^{7}$ & $00 . \infty$ & $\infty$. & $\therefore 00$ & $\infty 0 . \infty 0$ & $\infty$ & $\infty$ \\
\hline & $\omega$ & $1.7 \times 10^{6}$ & 010.90 & $\infty$ & - 00 & $\infty . \infty$ & $\infty$ & $\infty$ \\
\hline & 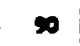 & $26 \times 20^{8}$ & 0.0 .00 & $\infty$ & - 0,0 & $\infty 0 . \infty 0$ & $\infty$ & $\infty$ \\
\hline & 10 & $22 \times 10^{2}$ & $0,0, \infty 0$ & $\infty$ & , $0 / 0$ & $\infty 0 . \infty 0$ & $\infty$ & $\infty$ \\
\hline Typ $30 \times 5=$ & 10 & $5.2 \times 20^{6}$ & 2210.220 & - & . - & 220,00 & - & 一 \\
\hline Incaloy izs & 300 & $522 \times 10^{\circ}$ & 00.00 & $\infty$ & - 0,0 & $\infty . \infty$ & $\infty$ & Qo \\
\hline Inconel cos & 100 & $32 \times 10^{\circ}$ & 010.90 & $\infty$ & - $0 / 0$ & $\infty 0 . \infty$ & no &.$\infty$ \\
\hline 20000163 & 100 & $2.2 \times 10^{0}$ & $0,0 . \omega_{3}$ & $\infty$ & - 0,0 & $\infty, \infty$ & $\infty$ & - $\infty$ \\
\hline $\sin x 30$ & 100 & $52 \times 20^{\circ}$ & $0,0, \infty 0^{3}$ & 一 & . - & $\infty, \infty \infty^{\circ}$ & - & 一 \\
\hline
\end{tabular}

Figure 5 shows a Time-Temperature-Sensitization (TTS) curve for Type $316 \mathrm{ELC}$ in pure water at $250^{\circ} \mathrm{C}$. There is only a very small region for which the cracks present lie in the range 20-50 $\mathrm{m}$. Figure 6 shows the effect of carbon on SCC of Type 316 stainless steels. The SCC resistance is improved greatly if the carbon content is below $0.02 \%$.

Fujiwara and others (1978) conducted a study to understand the effect of chemical composition on the SCC susceptibility of austenitic stainless steels in high temperature deionized water. The chemical compositions of steels used for making the test specimens are shown in Table 4. Double U-bend specimens were used for the tests. Cracking was observed only on the tension side of the inner specimen of double U-bend. Therefore, the SCC susceptibility was evaluated by maximum crack depth in this area of the specimen. 

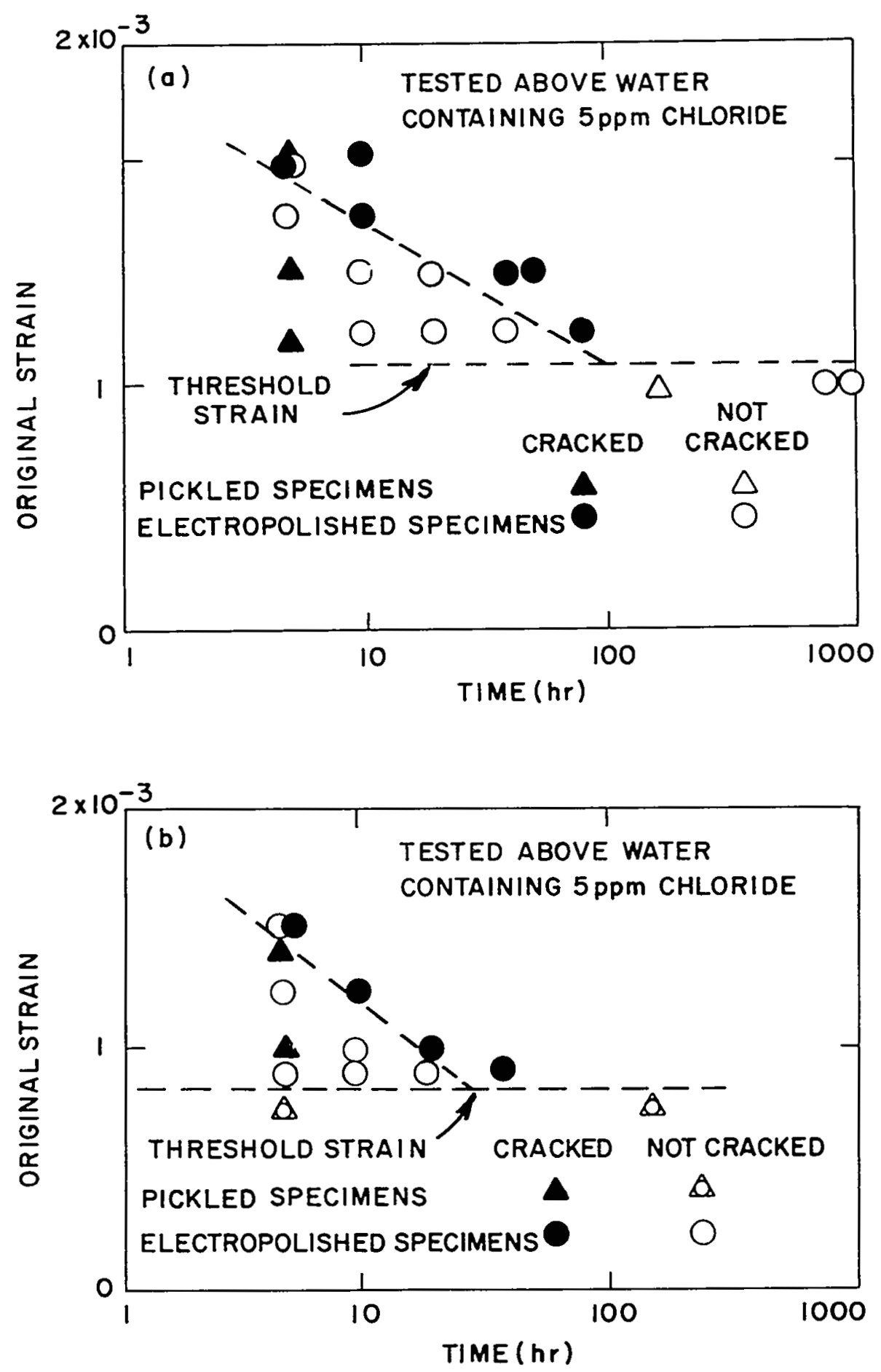

Figure 2 The relationship between original strain in bent-beam specimen and time-to-crack for (a) Type 321 stainless steel at $300^{\circ} \mathrm{C}$ and (b) Type 304 stainless steel at $200^{\circ} \mathrm{C}$ (Bircon, D., 1964). 


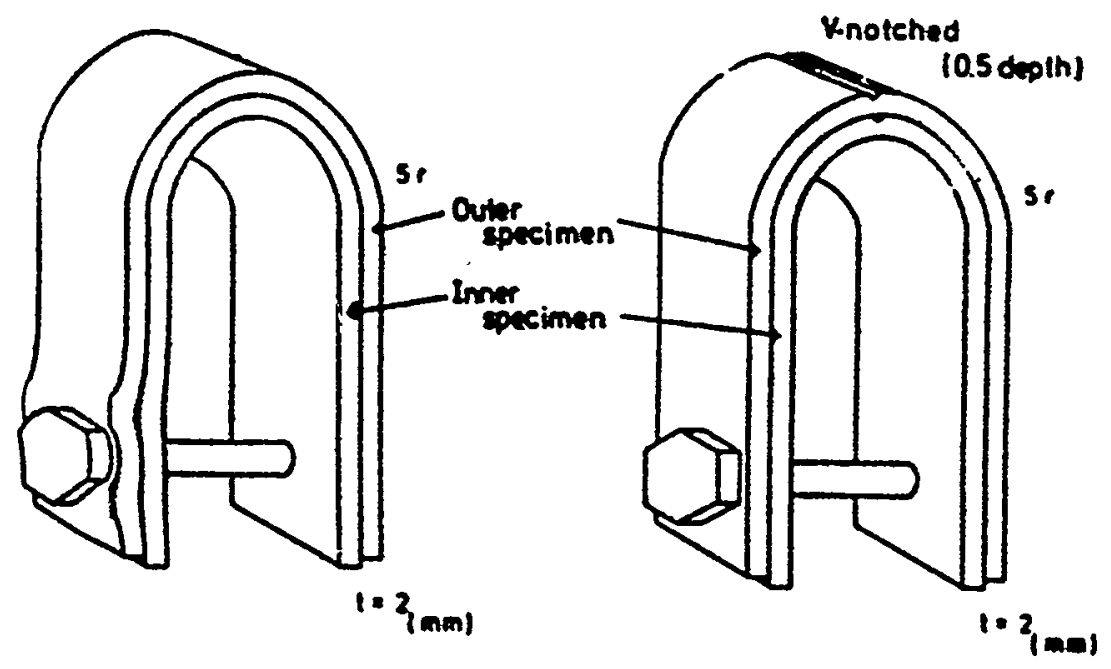

(o) Ploin epecimen

(b) V-notehed specinen

Figure 3(a) Schematic diagram of double U-bend type specimen.

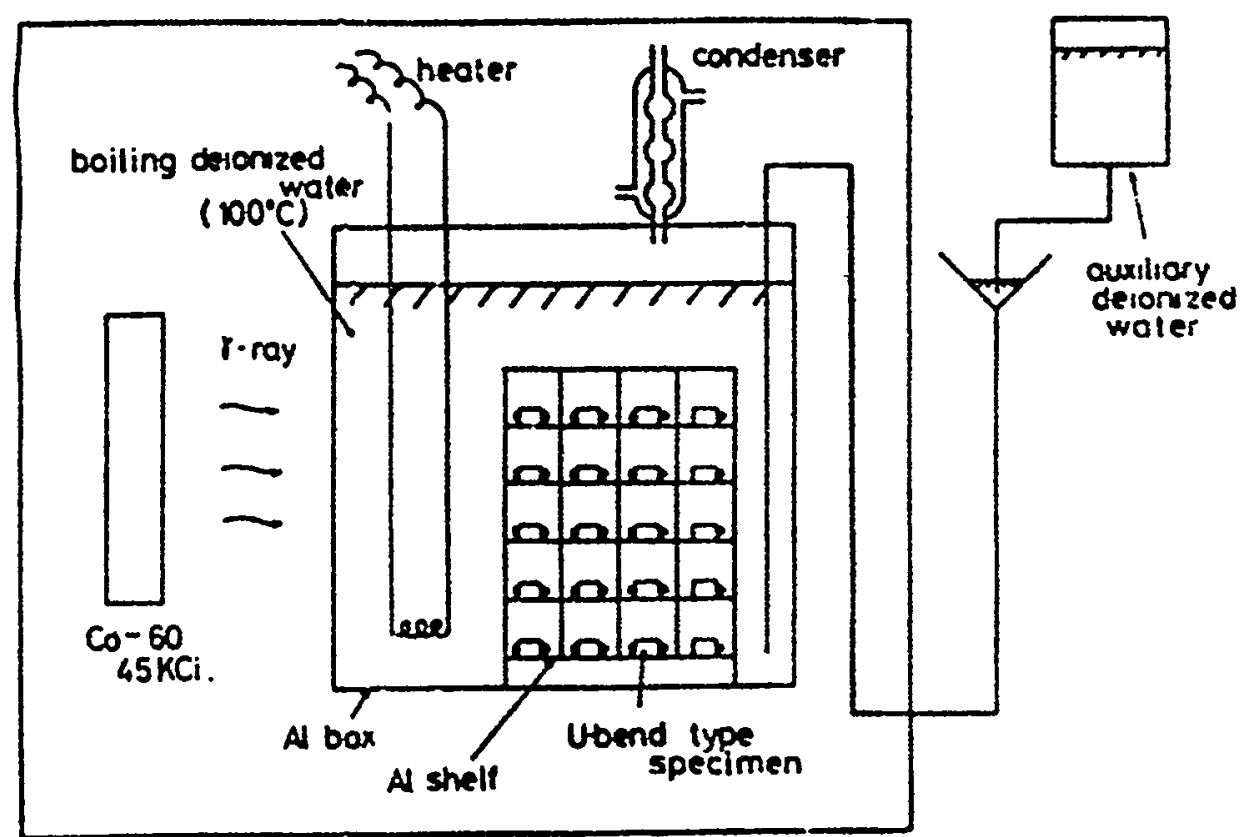

Figure 3(b) Schematic diagram of gamma-ray irradiation (first test) (JAERI-M-82-145, 1983). 
Table 3 Chemical composition of 316ELC specimens used (wt\%).

\begin{tabular}{|l|c|c|c|c|c|c|c|c|c|}
\hline Specimen & $\mathrm{C}$ & $\mathrm{Si}$ & $\mathrm{Mn}$ & $\mathrm{P}$ & $\mathrm{S}$ & $\mathrm{Ni}$ & $\mathrm{Cr}$ & Mo & $\mathrm{N}$ \\
\hline $316 \mathrm{ELC}-\mathrm{A}$ & 0.017 & 0.53 & 1.36 & 0.012 & 0.017 & 13.7 & 16.8 & 2.38 & 0.026 \\
$\begin{array}{l}316 \mathrm{ELC}-\mathrm{B} \\
(\mathrm{N} \text { added })\end{array}$ & 0.018 & 0.51 & 1.43 & 0.005 & 0.002 & 13.4 & 16.2 & 2.37 & 0.108 \\
\hline
\end{tabular}

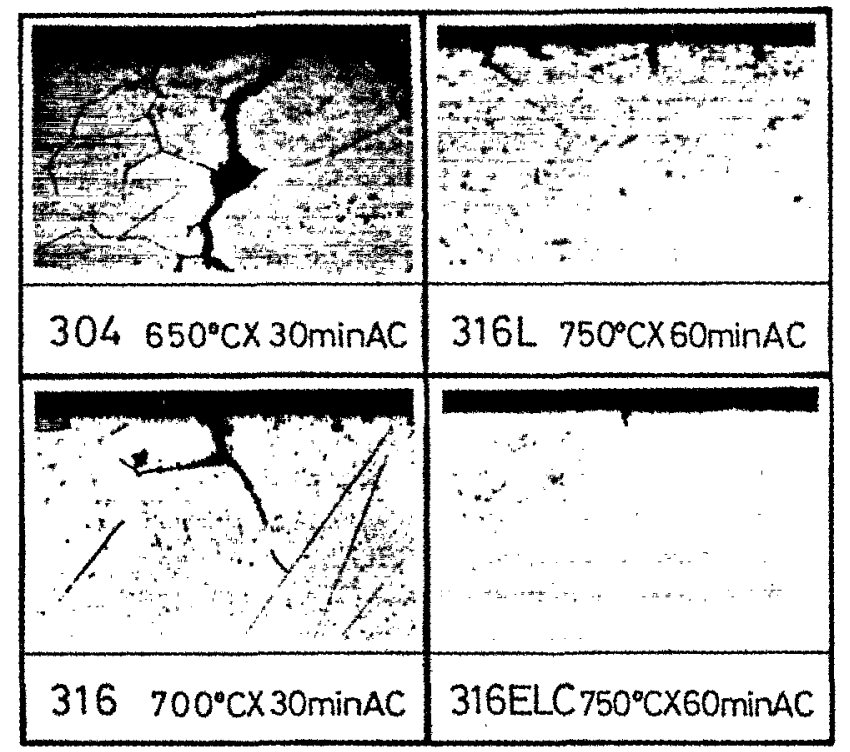

Figure 4 Microstructure of cracks

(Kowaka and others,1978).

For the different grades of Type 304 stalnless steels sensitized at $620^{\circ} \mathrm{C}$ for 24 hours and tested in deionized water at $285^{\circ} \mathrm{C}$ for 14 days, the following results were obtained. Increases in carbon content in the steel increased SCC susceptibility markedly. Cracks were found in Type $304 \mathrm{~L}$ SS with carbon content as low as $0.015 \%$. The effect of nitrogen in the steel on SCC depended on the carbon content of the steel. Although nitrogen tended to increase susceptibility when the carbon content was about $0.03 \%$, it had no adverse effect when the carbon content was about $0.15 \%$. SCC susceptibility decreased marked1y with an increase in molybdenum content and disappeared in stainless steel with over $2 \%$ molybdenum. It was observed that stainless steels which contained high phosphorous, silicon or sulfur with low carbon content, had low SCC susceptibility, and that steel which contained low phosphorous or silicon with high carbon content, had high SCC susceptibility. That is, the effect of carbon was dominant. 


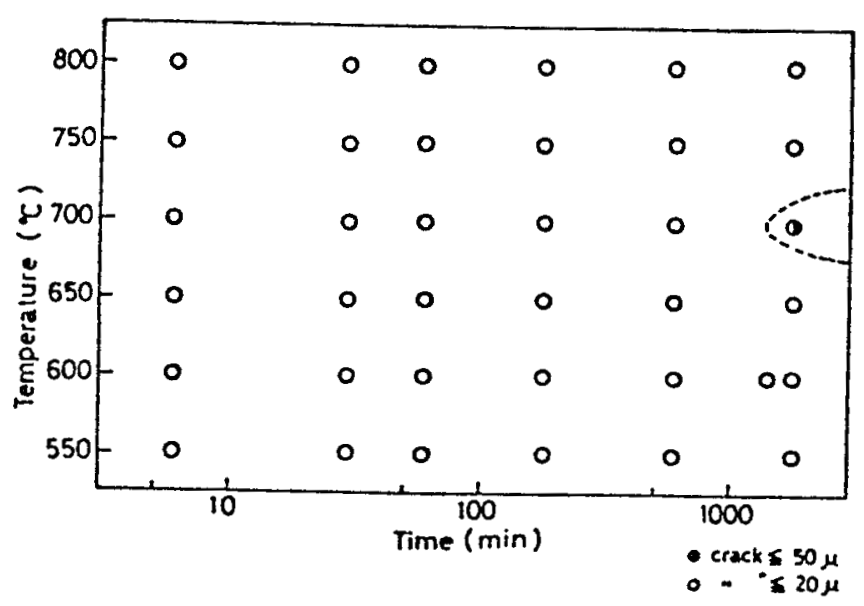

Figure 5 Time-temperature-sensitization curve for Type 316ELC for tests conducted in pure water at $250^{\circ} \mathrm{C}$ (Kowaka, et al., 1978).

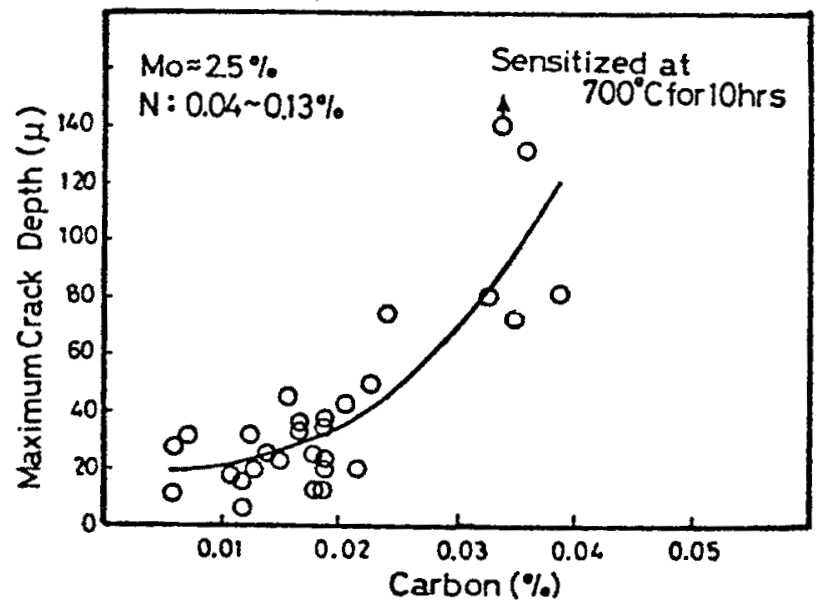

Figure 6 Effect of carbon on SCC of Type 316Ss in high temperature pure water at $250^{\circ} \mathrm{C}$ (Kowaka, et al., 1978). 
Table 4 Chemical composition of steels used for SCC testing (Fujiwara, et a1., 1978).

\begin{tabular}{|c|c|c|c|c|c|c|c|c|c|c|c|}
\hline \multirow[b]{2}{*}{ No. } & \multirow[b]{2}{*}{ Steels } & \multirow[b]{2}{*}{ C } & \multirow[b]{2}{*}{$\mathbf{S i}$} & \multirow[b]{2}{*}{$M n$} & \multicolumn{4}{|c|}{ Chemical Composition (\%) } & \multirow[b]{2}{*}{ Mo } & \multirow[b]{2}{*}{$\mathbf{N}$} & \multirow[b]{2}{*}{ Others } \\
\hline & & & & & $\mathbf{P}$ & $\mathbf{s}$ & NI & $\mathrm{Cr}$ & & & \\
\hline 1 & Type 304-1 & 0.075 & 0.52 & 0.95 & 0.010 & 0.024 & 9.20 & 18.22 & - & - & - \\
\hline 2 & Type $304-2$ & 0.057 & 0.47 & 1.74 & 0.034 & 0.021 & 9.48 & 18.49 & - & - & - \\
\hline 3 & Type 304L & 0.028 & 0.47 & 1.74 & 0.038 & 0.011 & 10.49 & 18.84 & 0.15 & 0.020 & - \\
\hline 4 & Type 304ELC & 0.015 & 0.44 & 1.84 & 0.038 & 0.020 & 10.73 & 18.73 & - & - & - \\
\hline 5 & Type 304ELN & 0.013 & 0.56 & 1.47 & 0.022 & 0.023 & 10.26 & 18.47 & - & 0.106 & - \\
\hline B & Type 321 & 0.050 & 0.53 & 1.10 & 0.023 & 0.011 & 8.93 & 18.05 & - & - & $\mathrm{TI}: 0.42$ \\
\hline 7 & Type 347 & 0.040 & 0.43 & 1.63 & 0.018 & 0.018 & 11.28 & 17.61 & - & - & $\mathrm{Nb}: 0.42$ \\
\hline 8 & Type 316ELC & 0.016 & 0.80 & 1.44 & 0.032 & 0.008 & 13.20 & 17.03 & 2.47 & - & - \\
\hline 9 & Type 316ELN & 0.014 & 0.39 & 1.72 & 0.024 & 0.010 & 13.89 & 17.70 & 2.29 & 0.090 & - \\
\hline 10 & Type 316ELN-Nb & 0.017 & 0.29 & 1.68 & 0.024 & 0.010 & 13.84 & 17.14 & 2.30 & 0.090 & Nb: 0.26 \\
\hline 11 & $25 \mathrm{Cr}-22 \mathrm{Ni}-2 \mathrm{Mo}$ & 0.011 & 0.30 & 1.83 & 0.014 & 0.010 & 22.12 & 25.04 & 2.11 & 0.120 & - \\
\hline 12 & Type 304LMo-1 & 0.027 & 0.53 & 1.79 & 0.021 & 0.016 & 10.71 & 18.07 & 0.52 & - & - \\
\hline 13 & Type 304LMo-2 & 0.027 & 0.48 & 1.71 & 0.022 & 0.017 & 10.61 & 17.99 & 1.01 & - & - \\
\hline 14 & Type 304 LMO-3 & 0.027 & 0.47 & 1.66 & 0.022 & 0.017 & 10.46 & 17.70 & 1.76 & - & - \\
\hline 15 & Type 304LN-1 & 0.026 & 0.48 & 1.80 & 0.024 & 0.017 & 10.64 & 18.49 & - & 0.054 & - \\
\hline 16 & Type $304 \mathrm{LN}-2$ & 0.031 & 0.47 & 1.87 & 0.023 & 0.018 & 10.78 & 18.14 & - & 0.073 & - \\
\hline 17 & Type $304 \mathrm{LN}-3$ & 0.026 & 0.45 & 1.72 & 0.023 & 0.016 & 10.65 & 18.87 & - & 0.097 & - \\
\hline 18 & Type 304LP & 0.053 & 0.50 & 1.01 & 0.005 & 0.015 & 8.89 & 17.75 & - & - & - \\
\hline 19 & Type 304HP & 0.035 & 0.54 & 0.92 & 0.102 & 0.005 & 9.12 & 19.26 & - & - & - \\
\hline 20 & Type 304LSi & 0.054 & 0.05 & 1.22 & 0.021 & 0.015 & 8.80 & 17.59 & - & - & - \\
\hline 21 & Type 304HSi & 0.032 & 1.80 & 1.00 & 0.012 & 0.005 & 9.02 & 19.43 & - & - & - \\
\hline 22 & Type 304HS & 0.033 & 0.50 & 0.88 & 0.021 & 0.099 & 9.32 & 19.80 & - & - & - \\
\hline
\end{tabular}

Figure 7 shows the results of SCC tests in delonized water at several temperatures from 100 to $300^{\circ} \mathrm{C}$ on representative austenitic stainless steels after heat treatment at $620^{\circ} \mathrm{C}$ for 24 hours. Maximum crack depth was observed at $200^{\circ} \mathrm{C}$. The ranking of SCC susceptibility among the steels was Type $304>$ $304 \mathrm{~L} \simeq 321>304 \mathrm{ELC} \simeq 347>316 \mathrm{ELN} \simeq 316 \mathrm{ELN}-\mathrm{Nb} \simeq 25 \mathrm{Cr}-22 \mathrm{Ni}-2 \mathrm{Mo}-\mathrm{ELC}$. For our Interest, the tests at $100^{\circ} \mathrm{C}$ showed crack depths of about $100 \mu$ in Type $304 \mathrm{~L}$ SS and $300 \mu$ in Type 321 SS.

There is some information on the effect of $\mathrm{Cl}^{-}$concentration mechanisms on the SCC of stainless steel. Figure 8 shows that Type 304 SS U-bend samples will fail by stress corrosion cracking in $100^{\circ} \mathrm{C}$ water containing $10 \mathrm{ppm} \mathrm{Cl}^{-}$ when the $\mathrm{Cl}^{-}$is concentrated on the specimen by means of a porous medium (Warren, D., 1960). Failures begin after about one month and all exposed samples failed after about nine months. For water containing $1500 \mathrm{ppm} \mathrm{C1}^{-}$, all specimens failed within about 3 days. 


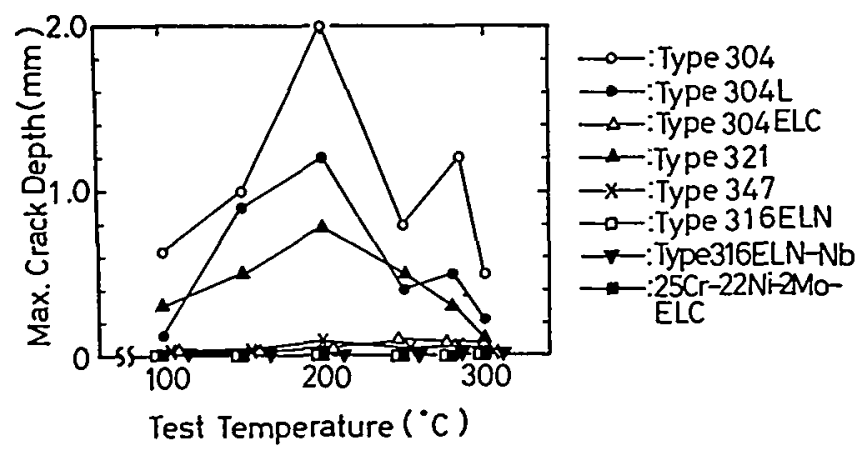

Figure 7 Comparison of SCC susceptibility on several representative austenitic stainless steels sensitized at $620^{\circ} \mathrm{C}$ for 24 hours (Fujiwara, et al., 1978).

Staehle, et al. (1970) studied the effect of alloy composition on stresscorrosion cracking of $\mathrm{Fe}-\mathrm{Cr}-\mathrm{Ni}$ base alloys. A wide range of alloys including Types 304, 304ELC $(0.026 \%$ C), 316 stainless steels and Incoloy 825 were tested in boiling $\mathrm{MgCl}_{2}$ solution at $154^{\circ} \mathrm{C}$. The specimens were wires approximately 15 $\mathrm{cm}$ long of which $8-10 \mathrm{~cm}$ contacted the solution. Most of the specimens were tested at $90 \%$ of their $0.2 \%$ offset yield stress. The primary experimental measurements were time-to-breaking of the wire specimens. Figure 9 shows a plot of percentage of specimens unbroken against exposure time for the various alloys. More than 90 percent of Incoloy 825 specimens were broken in about 100 days. Most of the Types 304, 304ELC, and 316 stainless steel specimens were broken in a day. These results confirm that high chloride environments are very detrimental to stress-corrosion resistance. Cracking of Incoloy 825 was also detected in low chloride ( $6 \mathrm{ppm}$ ) water, containing 10-18 ppm oxygen, at a temperature of $260^{\circ} \mathrm{C}$. Tensile stresses on the wire samples were equal to the yield strength (CO0-1319-82, 1970).

The slow-strain-rate testing method was used for Type 304L stainless steel specimens under tuff repository conditions at LLNL (UCRL-89988). The specimens were tested in both the solution annealed and in the "sensitized" conditions. Tests were conducted at strain rates of $10^{-4}$ and $2 \times 10^{-7} \mathrm{sec}^{-1}$ in air-sparged tuff-conditioned $\mathrm{J}-13$ water at $150^{\circ} \mathrm{C}$. The test results shown in Table 5 indicate that stress-assisted failure is unlikely (UCRL-89988, 1983, and McCright, et al. 1984). However, it should be pointed out that these tests are accelerated tests and do not address the very long term exposures which may be needed to initiate cracks. This work also did not include the potentfally adverse effects of gamma radiolysis of solutions which would be an added source of oxidizing species. 


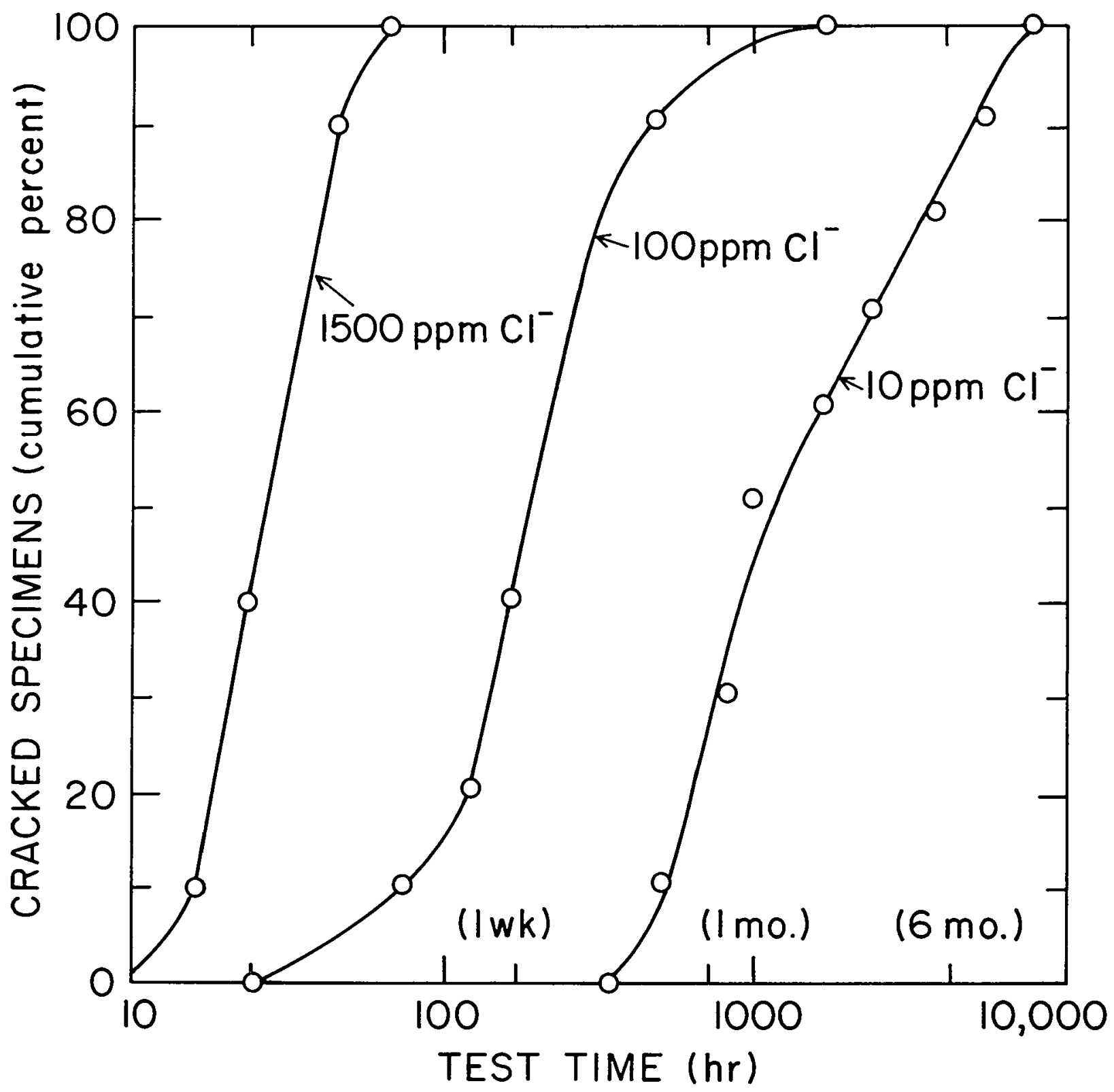

Figure 8 Effect of chloride added as NaCl on cracking of Type 304 stainless steel at $100^{\circ} \mathrm{C}$. Solution transported by porous material to specimen (Warren, D., 1960). 
Table 5 Slow-strain-rate test results for 304L stainless steel in $150^{\circ} \mathrm{C}$ tuff-conditioned J-13 water (UCRL-89988, 1983).

\begin{tabular}{|c|c|c|c|c|c|}
\hline $\begin{array}{c}\text { Metallurgical } \\
\text { Condition }\end{array}$ & Environment & $\begin{array}{c}\text { Strain } \\
\text { Rate } \\
\left(\mathrm{sec}^{-1}\right)\end{array}$ & $\begin{array}{c}\text { Elongation } \\
(x)\end{array}$ & $\begin{array}{l}\text { Yield } \\
\text { Stress } \\
\text { (ksi) }\end{array}$ & Comments \\
\hline $\begin{array}{l}S A(a) \\
S A\end{array}$ & $\begin{array}{l}\mathrm{J}-13 \\
\mathrm{~J}-13\end{array}$ & $\begin{array}{l}10^{-4} \\
10^{-4}\end{array}$ & $\begin{array}{l}54.0 \\
52.0\end{array}$ & $\begin{array}{l}25.8 \\
27.1\end{array}$ & $\begin{array}{l}\text { reolicate tests } \\
\text { ductile fractures }\end{array}$ \\
\hline $\begin{array}{l}S A+S(b) \\
S A+S\end{array}$ & $\begin{array}{l}J-13 \\
J-13\end{array}$ & $\begin{array}{l}10^{-4} \\
10^{-4}\end{array}$ & $\begin{array}{l}49.6 \\
51.9\end{array}$ & $29 . \overline{-6}$ & $\begin{array}{l}\text { reolicate tests } \\
\text { ductile fractures }\end{array}$ \\
\hline$S A+S$ & air & $10^{-4}$ & 49.0 & 29.4 & ductile fracture \\
\hline $\begin{array}{l}S A+S \\
S A+S\end{array}$ & $\begin{array}{l}j-13 \\
j-13\end{array}$ & $\begin{array}{l}2 \times 10^{-7} \\
2 \times 10^{-7}\end{array}$ & $\begin{array}{rr}7 & 49.0 \\
7 & 48.0\end{array}$ & $\begin{array}{l}26.6 \\
27.2\end{array}$ & $\begin{array}{l}\text { replicate tests } \\
\text { ductile fractures }\end{array}$ \\
\hline
\end{tabular}

(a) $S A=$ Solution-annealed $\left(1050^{\circ} \mathrm{C}, 15\right.$ minutes; water quench)

(b) $\mathrm{SA}+\mathrm{S}$ a Solution-annealed + "sensitizing" treatment (as above, then $600^{\circ} \mathrm{C}, 10$ hours, air c001)

In addition to the slow-strain-rate testing method, work is underway at LLNL to study the behavior of stressed Type 304L specimens in tuff repository conditions using U-bend irradiation corrosion tests and bent beam stress corrosion tests (UCRL-91804, 1984). The U-bend specimens of Type 304 and 304L In annealed and annealed-and-sensitized conditions were tested at $50^{\circ} \mathrm{C}$ and $90^{\circ} \mathrm{C}$ in autoclaves kept under ${ }^{60} \mathrm{Co}$ irradiation. The specimens were stressed beyond the yield strength of the material. Table 6 gives a summary of test results after three months of exposure. According to this investigation, only a few of the Type 304 specimens cracked and there was no evidence of pitting or other forms of non-uniform attack on Type 304L specimens after five months of exposure. However, there may be a long incubation period before cracking can be initiated. Therefore, the U-bend irradiation corrosion tests for Type $30.4 \mathrm{~L}$ are being continued at LLNL.

Bent beam stress corrosion tests for Types 304 and $304 \mathrm{~L}$ specimens were conducted at LLNL in tuff-conditioned J-13 water at $100^{\circ} \mathrm{C}$ and in saturated vapor above the water. The specimens were heavily cold worked, welded, and some given a post-weld anneal, and some given a sensitizing treatment $\left(700^{\circ} \mathrm{C}\right.$ for 8 hours), and finally were stressed to $90 \%$ of the room temperature yield strength. The test conditions and specimen details along with the status of stress corrosion cracking test results at the reporting time are shown in Table 7. At the reporting time (September 1984); none of the bent beam specimens have cracked. As in the case of U-bend tests, there is an incubation period for the initiation of SCC, therefore, these tests are being continued. 


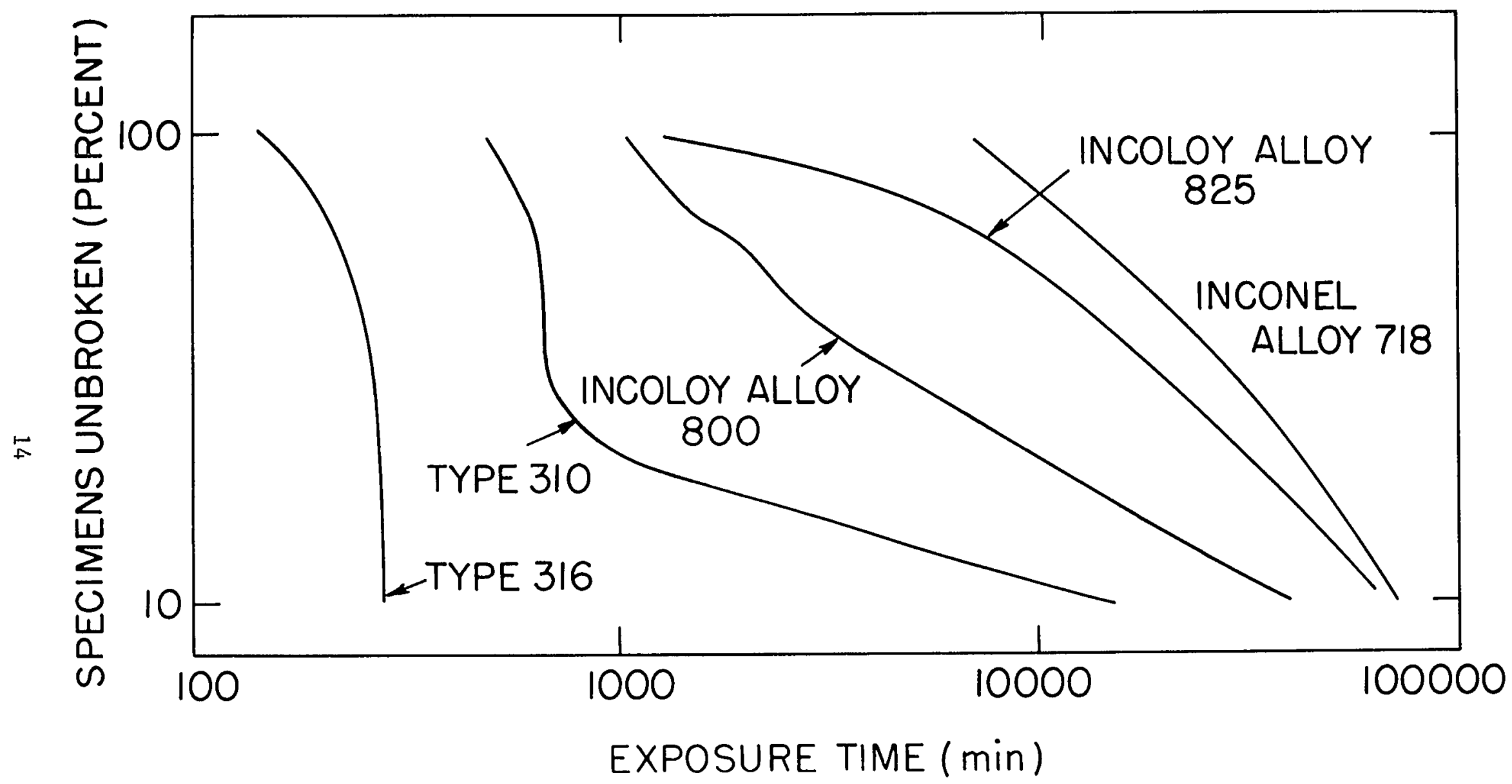

Figure 9 Percentage of specimens unbroken plotted against exposure time for various commercial alloys exposed to a boiling magnesium chloride solution at $154^{\circ} \mathrm{C}$. Specimens stressed to $90 \%$ of the yield stress. 
'Table 6 Stress corrosion cracking test results from U-bend specimens exposed to irradiated J-13 water, crushed tuff rock, and water vapor. Results after 3 months exposure (UCRL-91804, 1984).

\begin{tabular}{|c|c|c|c|c|c|c|}
\hline \multirow[t]{3}{*}{ Material } & \multicolumn{6}{|c|}{$\begin{array}{l}\text { No. of Specimens Cracked/No. of Specimens Tested } \\
\text { Environment }\end{array}$} \\
\hline & \multicolumn{3}{|c|}{$50^{\circ} \mathrm{C}\left(6 \times 10^{5} \mathrm{rads} / \mathrm{hr}\right)$} & \multicolumn{3}{|c|}{$90^{\circ} \mathrm{C}\left(3 \times 10^{5} \mathrm{rads} / \mathrm{hr}\right)$} \\
\hline & $\begin{array}{c}\text { Rock + } \\
\text { Water }\end{array}$ & $\begin{array}{r}\text { Rock }+ \\
\text { Vapor }\end{array}$ & Vapor & $\begin{array}{r}\text { Rock + } \\
\text { Water }\end{array}$ & $\begin{array}{r}\text { Rock }+ \\
\text { Vapor }\end{array}$ & Vapor \\
\hline 304 sS & $0 / 4$ & $0 / 4$ & $2 / 4$ & $0 / 4$ & $3 / 4$ & $1 / 4$ \\
\hline $304 \mathrm{~L}$ SS & $0 / 4$ & $0 / 4$ & $0 / 4$ & $0 / 4$ & $0 / 4$ & $0 / 4$ \\
\hline
\end{tabular}

Clearly, the data from this literature review suggest that stressed and sensitized Types $304 \mathrm{~L}, 316 \mathrm{~L}$, and 321 stainless steels are susceptible to SCC in pure water and water containing very low concentrations of $\mathrm{Cl}^{-}$. Under high $\mathrm{Cl}^{-}$concentrations cracking occurs more readily and even Incoloy 825 may be cracked.

The concentrations of $\mathrm{Cl}^{-}$and other ions in the repository water coming in contact with a waste package could be much higher than the reference J-13 water due to initial evaporation of groundwater and subsequent dissolution of previously precipitated salts. In addition, there could be a build-up of oxidizing species in the repository waters due to gamma radiolysis effects. 
Table 7 Status of stress corrosion cracking test results for four-point load, bent-beam specimens exposed to $\mathrm{J}-13$ water and steam and stressed to $90 \%$ yield stress (UCRL-91804, 1984).

\begin{tabular}{|c|c|c|c|}
\hline $\begin{array}{l}\text { Material } \\
\text { and Process } \\
\text { Condition }\end{array}$ & $\begin{array}{c}\text { Exposure } \\
\text { (h) }\end{array}$ & $\begin{array}{l}100^{\circ} \mathrm{C} \mathrm{J}-13 \text { Water } \\
\text { No. Specimens Cracked/ } \\
\text { No. Specimens Tested }\end{array}$ & $\begin{array}{c}100^{\circ} \mathrm{C} \text { Steam } \\
\text { No. Specimens Cracked/ } \\
\text { No. Specimens Tested }\end{array}$ \\
\hline $\begin{array}{l}304-C S W * \\
304 L-C S W \\
316 L-C S W \\
321-C S W\end{array}$ & $\begin{array}{l}4016 \\
4016 \\
4016 \\
4016\end{array}$ & $\begin{array}{l}0 / 9 \\
0 / 9 \\
0 / 9 \\
0 / 9\end{array}$ & $\begin{array}{l}0 / 9 \\
0 / 9 \\
0 / 9 \\
0 / 9\end{array}$ \\
\hline $\begin{array}{l}304-\text { COW } \\
304 L-\text { COW } \\
316 L-\text { COW } \\
321-\text { COW }\end{array}$ & $\begin{array}{l}2000 \\
2000 \\
2000 \\
2000\end{array}$ & $\begin{array}{l}0 / 3 \\
0 / 3 \\
0 / 3 \\
0 / 3\end{array}$ & $\begin{array}{l}0 / 3 \\
0 / 3 \\
0 / 3 \\
0 / 3\end{array}$ \\
\hline \multicolumn{4}{|c|}{$\begin{array}{l}* \mathrm{KEY} \\
\mathrm{C}=\text { cold-worked, } 20 \% \\
\mathrm{~S}=\text { furnace "sensitized" }\left(700^{\circ} \mathrm{C} \text { for } 8 \text { hours }\right) \\
\mathrm{W}=\text { double-pass welded } \\
\mathrm{O}=\text { acts as a placeholder for each of the above symbols } \\
\text { Examples: } 304 \mathrm{~L} \mathrm{CSW} \mathrm{means} \mathrm{that} \mathrm{the} \mathrm{plate} \mathrm{or} \mathrm{specimen} \mathrm{is} \mathrm{Type} 304 \mathrm{~L} \text { stainless } \\
\text { steel in the cold-worked, sensitized and welded condition. } \\
\text { 316L COW means that the plate or specimen is Type } 316 \mathrm{~L} \text { stainless } \\
\text { steel in the cold-worked and welded condition without any furnace } \\
\text { heat treatment to produce a "sensitized" structure. }\end{array}$} \\
\hline
\end{tabular}




\section{GEOCHEMICAL CONDITIONS IN A TUFF REPOSITORY}

There is no information available currently on the composition of groundwater or steam that will be present in the proposed unsaturated zone of the tuff repository. However, the groundwater chemistry is thought to be similar to the reference $\mathrm{J}-13$ groundwater composition given in Table 8 . As shown in this table, the water contains $7.5 \mathrm{ppm} \mathrm{Cl}^{-}$and it will be saturated with oxygen from the surrounding air. Initial evaporation of groundwater and subsequent dissolution of previously precipitated salt can make the concentration of $\mathrm{CI}^{-}$and other ions in the water coming in contact with a waste package much higher than the values currently assumed. More details of tuff repository conditions are described elsewhere (NUREG/CR-3091, Vol. 7 ).

Table 8 Reference groundwater composition for tuff repositories based on composition of water in Jackass Flats Wel1 $\mathrm{J}-13$ at the Nevada Test Site (UCRI-89988, 1983).

\begin{tabular}{|l|c|}
\hline Constituent & $\begin{array}{c}\text { Concentration } \\
\text { (mg/liter) }\end{array}$ \\
\hline Lithium & 0.05 \\
Sodium & 51.0 \\
Potassium & 4.9 \\
Magnesium & 2.1 \\
Calcium & 14.0 \\
Strontium & 0.05 \\
Barium & 0.003 \\
Iron & 0.04 \\
Aluminum & 0.03 \\
Silica & 61.0 \\
Fluoride & 2.2 \\
Chloride & 7.5 \\
Carbonate & 0.0 \\
Bicarbonate & 120.0 \\
Sulfate & 22.0 \\
Nitrate & 5.6 \\
Phospate & 0.12 \\
\hline pH - slightly basic & $(7.1)$ \\
\hline
\end{tabular}




\section{EXPERIMENTAL METHOD}

The stress corrosion susceptibility of Types 304L, 316L, and 321 stainless steels, and Incoloy 825 under simulated tuff repository conditions was evaluated using the V-notched C-ring method (ASTM, 1979). Each alloy was tested in the as-received (solution annealed) as well as heat treated (sensitized) conditions.

The stressed specimens were tested in boiling synthetic J-13 and tentimes concentrated J-13 water in the presence of crushed Topopah Spring tuff. The use of the concentrated solution represents the situation when salts, precipitated after evaporation of groundwater, are redissolved in cooler water subsequently percolating towards the repository horizon. Specimens were also tested in the steam phase above the two solutions. It should be noted that throughout this study, for simplicity, reference will be made to testing in J-13 or ten-times-concentrated J-13 water. In fact, the concentrations of these starting solutions change with time due to reaction with the tuff - see Section 6. In the present tests, steam will be present at approximately $100^{\circ} \mathrm{C}$, although in a repository the steam temperature could be as high as the container temperature $\left(\simeq 300^{\circ} \mathrm{C}\right)$. Details of the test plan, materials, specimen, preparation, apparatus, test procedures, and analytical techniques are described below.

\subsection{Test Plan}

Tests were conducted in parallel for three-,six- and twelve-month durations. Thus, there were six independent test vessels, three for each solution. To check reproducibility, triplicate samples were used for each test condition. A total of 288 specimens were used in this test plan as described in the test matrix given in Table 9.

\subsection{Materials and Specimen Preparation}

\subsubsection{C-Ring Specimens}

Types 304L, 316L and 321 stainless steel and Incoloy 825 were the material selected for the SCC tests. Seamless 0.75-inch o.d. x 0.125-inch wall tubing of stainless steel and 0.84 -inch $0 . d$. $\times 0.109$-inch wall tubing for the Incoloy were purchased from Royce Aerospace Materials Corporation*. Chemical compositions and mechanical properties of these alloys, as supplied by the vendor, are given in Tables 10 and 11 , respectively.

It is important to note that although the carbon contents fall within specifications for the four materials, they are all at the low end of the permissible range. The respective carbon concentrations for the Types 304L, $316 \mathrm{~L}$, and 321 stainless steels and Incoloy 825 are $0.016,0.016,0.028$ and 0.020 wt. $\%$ compared to maximum permissible values of $0.03,0.03,0.08$, and

\footnotetext{
*West Babylon, New York
} 
Table 9 Test matrix for stress corrosion of candidate stainless steel and Incoloy $-825 .^{a}$

\begin{tabular}{|c|c|c|c|c|}
\hline \multirow[b]{2}{*}{ Sample Condition } & \multirow[b]{2}{*}{ Exposure Mediumb } & \multicolumn{3}{|c|}{$\begin{array}{l}\text { Total Exposure Time } \\
\text { and Number of Samples }\end{array}$} \\
\hline & & 3 Months & 6 Months & 12 Months \\
\hline $\begin{array}{l}\text { Solution Annealed (SA) } \\
\text { SA + Sensitized } \\
\text { SA } \\
\text { SA + Sensitized } \\
\text { SA } \\
\text { SA + Sensitized } \\
\text { SA } \\
\text { SA + Sensitized }\end{array}$ & $\begin{array}{ll}\mathrm{J}-13 & \text { Steam } \\
\mathrm{J}-13 & \text { Steam } \\
\mathrm{J}-13 & \text { Water } \\
\mathrm{J}-13 & \text { Water } \\
& \\
(\mathrm{J}-13 & \text { Steam }) \times 10^{\mathrm{C}} \\
(\mathrm{J}-13 & \text { Steam }) \times 10 \\
(\mathrm{~J}-13 & \text { Water }) \times 10 \\
(\mathrm{~J}-13 & \text { Water }) \times 10\end{array}$ & $\begin{array}{l}3 \\
3 \\
3 \\
3 \\
\\
3 \\
3 \\
3 \\
3\end{array}$ & $\begin{array}{l}3 \\
3 \\
3 \\
3 \\
\\
3 \\
3 \\
3 \\
3\end{array}$ & $\begin{array}{l}3 \\
3 \\
3 \\
3 \\
\\
3 \\
3 \\
3 \\
3\end{array}$ \\
\hline \multicolumn{5}{|c|}{$\begin{array}{l}\text { a) This test matrix comprising } 72 \text { samples constituted the tests on one of the } \\
\text { four candidate materials. An identical matrix were used for all eight } \\
\text { materials and the total number of all specimens tested were } 288 \text {. } \\
\text { b) All tests were conducted in the presence of crushed tuff. } \\
\text { c) This environment was the steam/air phase above lox concentrated J-13 well } \\
\text { water. }\end{array}$} \\
\hline
\end{tabular}

Table 10 Vendor supplied chemical analysis of test alloys (weight percent).

\begin{tabular}{|l|c|c|c|c|c|c|c|c|c|c|c|}
\hline Alloy & C & Mn & Si & P & S & Cr & Ni & Mo & Ti & Al & Fe \\
\hline $\begin{array}{l}\text { Type } \\
\text { 304L SS }\end{array}$ & 0.016 & 1.95 & 0.48 & 0.038 & 0.025 & 18.54 & 10.55 & - & - & - & Balance \\
$\begin{array}{l}\text { Type } \\
\text { 316L SS }\end{array}$ & 0.016 & 1.94 & 0.37 & 0.035 & 0.010 & 16.66 & 12.80 & 2.02 & - & - & Balance \\
$\begin{array}{l}\text { Type } \\
\text { 321 SS } \\
\text { Incoloy } \\
825\end{array}$ & 0.028 & 1.03 & 0.74 & 0.026 & 0.002 & 17.41 & 10.75 & - & 0.24 & - & Balance \\
\hline
\end{tabular}


Table 11 Mechanical properties of as-received test alloys (vendor supplied data).

\begin{tabular}{|c|c|c|c|c|c|c|}
\hline Alloy & $\begin{array}{r}\text { U1 } \\
\text { Tensil } \\
\text { (MPa) }\end{array}$ & $\begin{array}{l}\text { Imate } \\
\text { Strength } \\
\quad \text { (ksi) }\end{array}$ & $\begin{array}{r}0.2 \% \\
\text { Yield } \\
\text { (MPa) }\end{array}$ & $\begin{array}{l}\text { Offset } \\
\text { Strength } \\
\quad \text { (ksi) }\end{array}$ & $\begin{array}{c}\text { Elongation } \\
(\%)\end{array}$ & $\begin{array}{c}\text { Rockwell } \\
\text { Hardness } \\
\quad\left(R_{B}\right)\end{array}$ \\
\hline $\begin{array}{l}\text { Type 304L SS } \\
\text { Type } 316 \mathrm{~L} \text { SS } \\
\text { Type } 321 \text { SS } \\
\text { Incoloy } 825\end{array}$ & $\begin{array}{l}536 \\
562 \\
558 \\
799\end{array}$ & $\begin{array}{r}77.8 \\
81.5 \\
81.0 \\
116.0\end{array}$ & $\begin{array}{l}276 \\
254 \\
225 \\
475\end{array}$ & $\begin{array}{l}40.1 \\
36.9 \\
32.7 \\
68.9\end{array}$ & $\begin{array}{l}65.3 \\
59.2 \\
65.0 \\
36.0\end{array}$ & $\begin{array}{l}85.2 \\
69.4 \\
78.0 \\
95.0\end{array}$ \\
\hline
\end{tabular}

0.05 wt.\%, respectively. Because of this, the materials tested are less likely to become sensitized compared to steels with higher carbon levels.

C-ring test specimens were fabricted from the as-received (solution annealed) as well as from heat treated (sensitized) tubing for each alloy. During heat treatment the tubing was maintained at $600^{\circ} \mathrm{C}$ for 100 hours followed by furnace cooling. This treatment was expected to sensitize the specimens because of the formation of chromium-depleted zones adjacent to grain boundary carbides. A comparison of microstructures for the as-received (annealed) and heat treated condition showed that the heat treatment had probably sensitized the stainless steels by precipitating carbides at the grain boundaries. Such an observation was much less evident in the case of Incoloy 825, for which the heat treatment had resulted in the precipitation of secondphase particles (probably TiC) within the grains.

It is interesting to note that sensitization in the stainless steels is slightly stronger near the surfaces of the C-ring specimens. Figure 10 shows this effect for Type 304L stainless steel for which the grain boundaries near the outer diameter are more heavily etched. This preferential sensitization is most likely due to unavoidable contamination from lubricants during mill operations. For a stainless steel container, this observation suggests that similar surface contamination during its production or handling could enhance its susceptibility to sensitization and, therefore, to stress corrosion cracking.

The procedure for testing C-ring samples is given elsewhere (ASTM, 1979). The surfaces of the as-received and heat-treated tubing were brought to a consistent finish by polishing with 600-grit silicon carbide paper. Notched C-ring specimens were machined from the polished tubing according to the specifications given in Figure 11. Before stressing, each specimen was degreased in trichloroethane and then cleaned with Alconox soap, methanol, and distilled water.

The C-ring specimens are loaded such that stress levels at the apex are 90 percent of the elastic limit at room temperature calculated for the unnotched condition. Therefore, one smooth C-ring specimen for each of the 


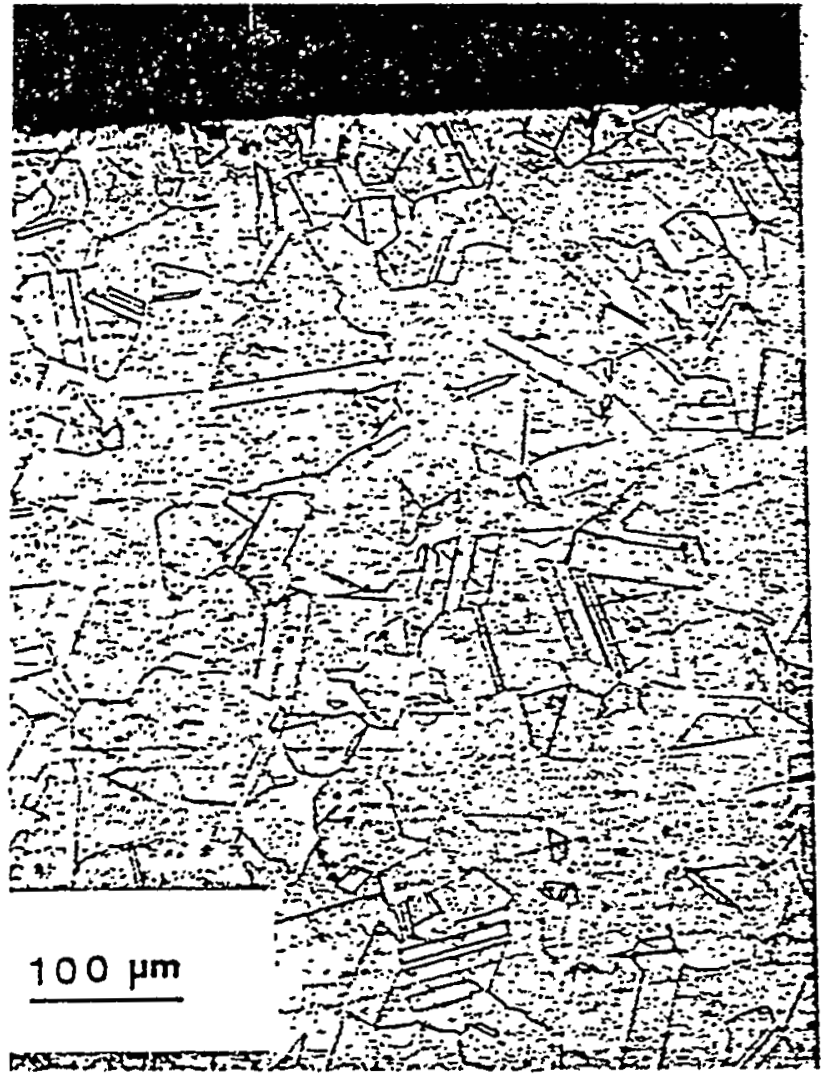

(a)

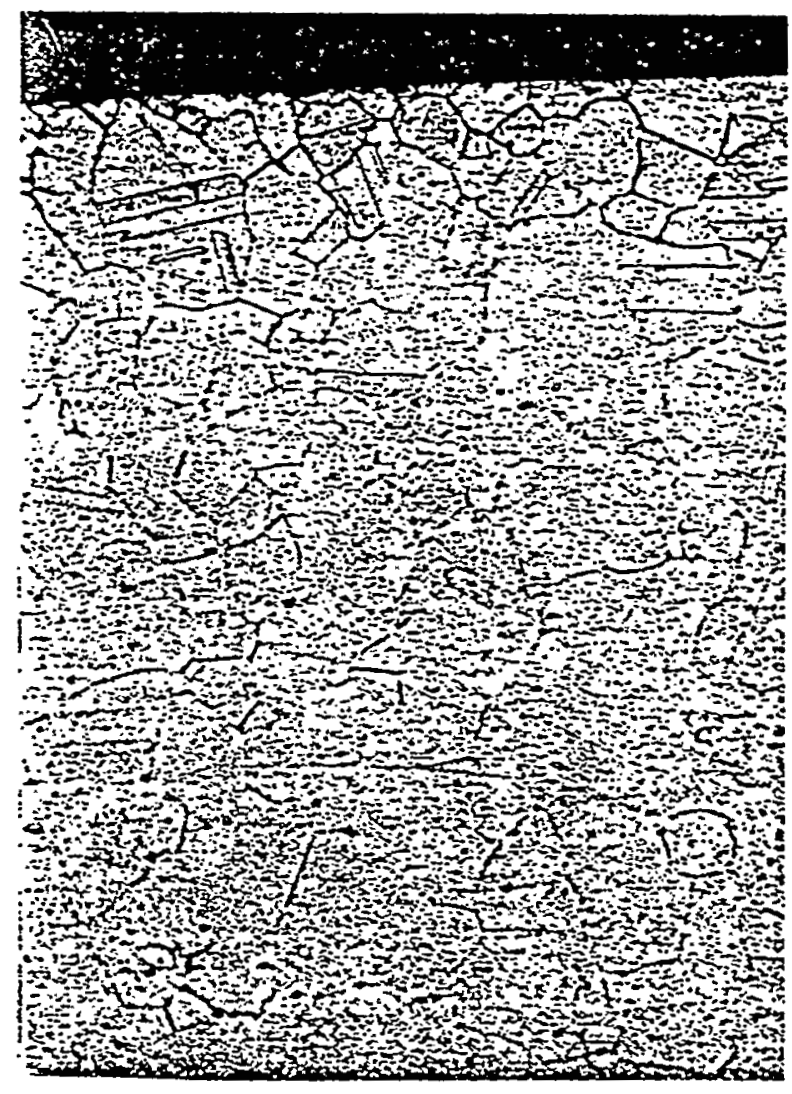

(b)

Figure 10 Microstructure of Type 304L stainless steel.

(a) As-received, etched in glyceregia.

(b) Sensitized at $600^{\circ} \mathrm{C}$ for 100 hours, etched in oxalic acid.

eight alloys (three stainless steels and Incoloy 825 in the as-received and sensitized conditions), identical in dimensions to notched test specimens, was tested in an Instron machine to obtain stress-strain characteristics. A typical load vs deflection curve is shown in Figure 12 for Type 304L sensitized stainless steel; the C-ring was stressed in the same orlentation as expected from the usual nut and bolt arrangement. The load and deflection at the elastic limit (shown by arrow) obtained from such curves are given in Table 12. The notched C-ring test specimens were stressed with the help of commercial stainless steel nuts and bolts such that the change in $0 . d$. was $90 \%$ of the deflection at the elastic limit (Table 12).

In the present procedure the applied tensile stress in most of the volume of a specimen will be within the elastic limit, which could correspond to 


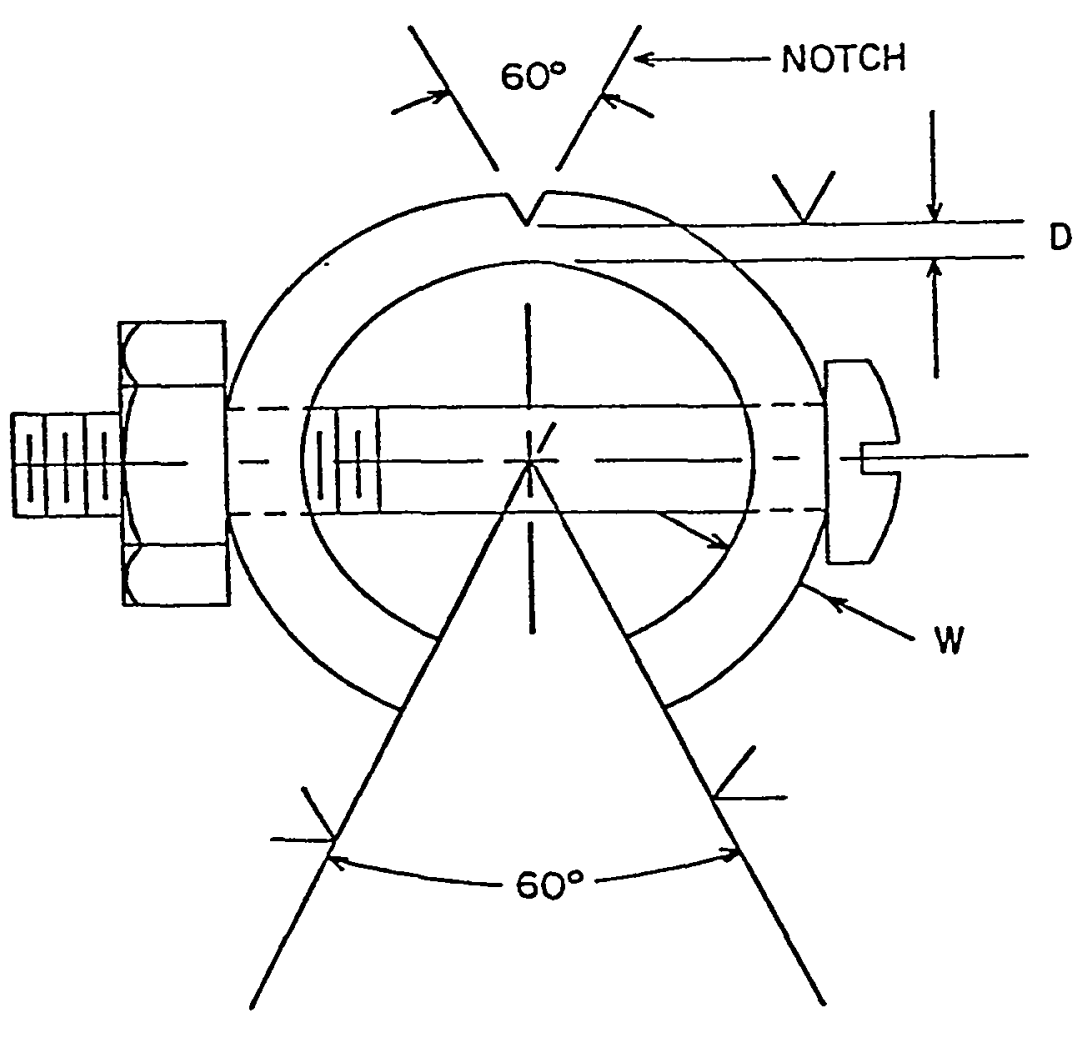

$4 X$ SIZE

Figure 11 C-ring specimen design.

those expected in a normal waste container. However, the actual stress in the cross section of a test specimen through the notch will be higher than the "90\% of elastic limit" value because of stress concentration effects. This was confirmed by the observation that when the stress on the selected specimens was removed, the deflection was only partially recovered because local plastic deformation had occurred. The rationale of having plastic stresses near the notch is that in a realistic situation, similar plastic deformation is possible at dents, flaws, or inclusions in the container surface. Inadvertent mishandling during transportation or emplacement of the waste can also cause plastic deformation in a container.

An attempt was made to determine the strain present on the surface of a smooth C-ring specimen. Three longitudinal and one transverse strain gauge were attached on the outer surface of the specimen which was then compressed in an Instron machine. A typical load vs strain curve from these measurements 


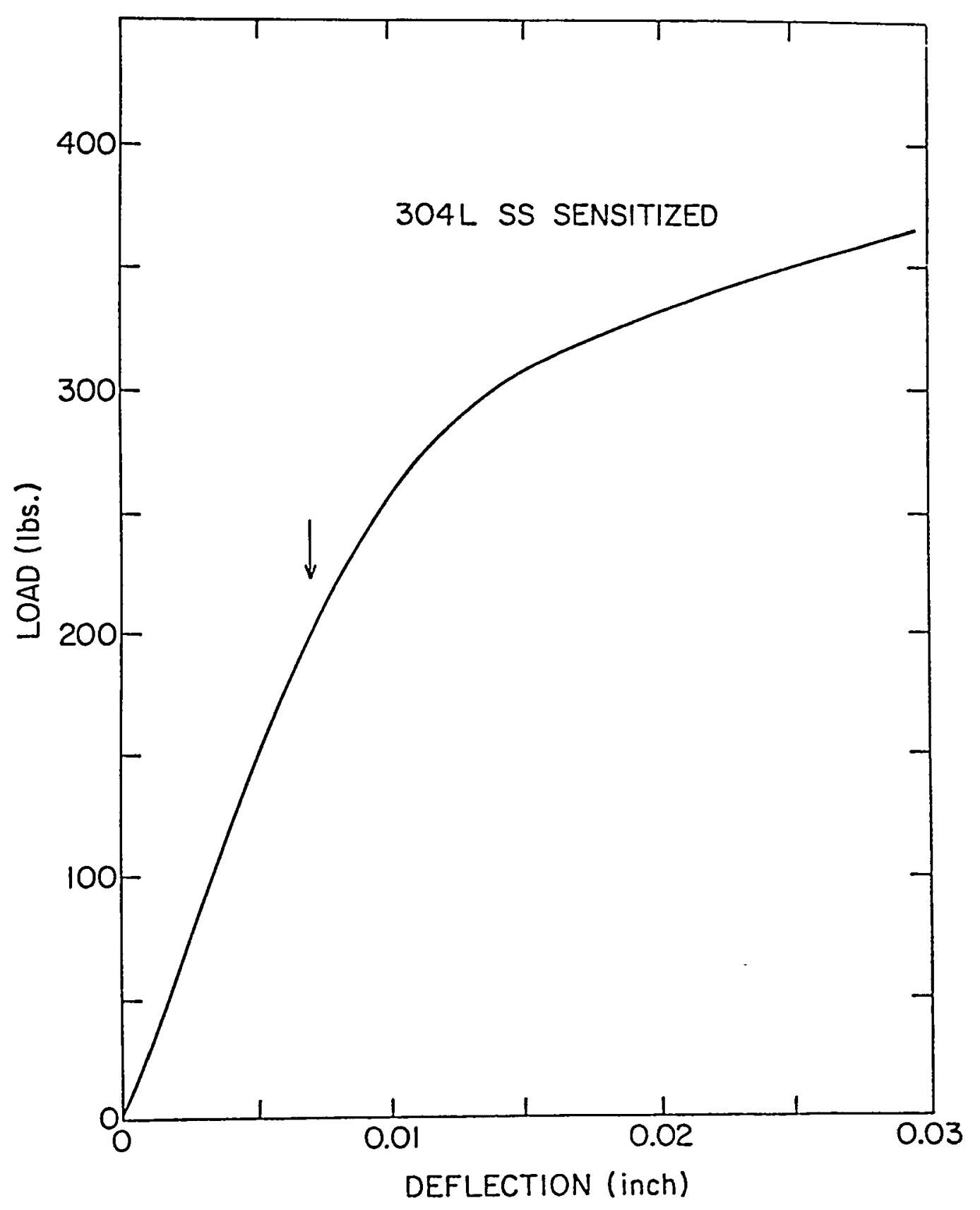

Figure 12 Load vs deflection of Type 304L stainless steel sensitized C-ring test specimen under stress. 


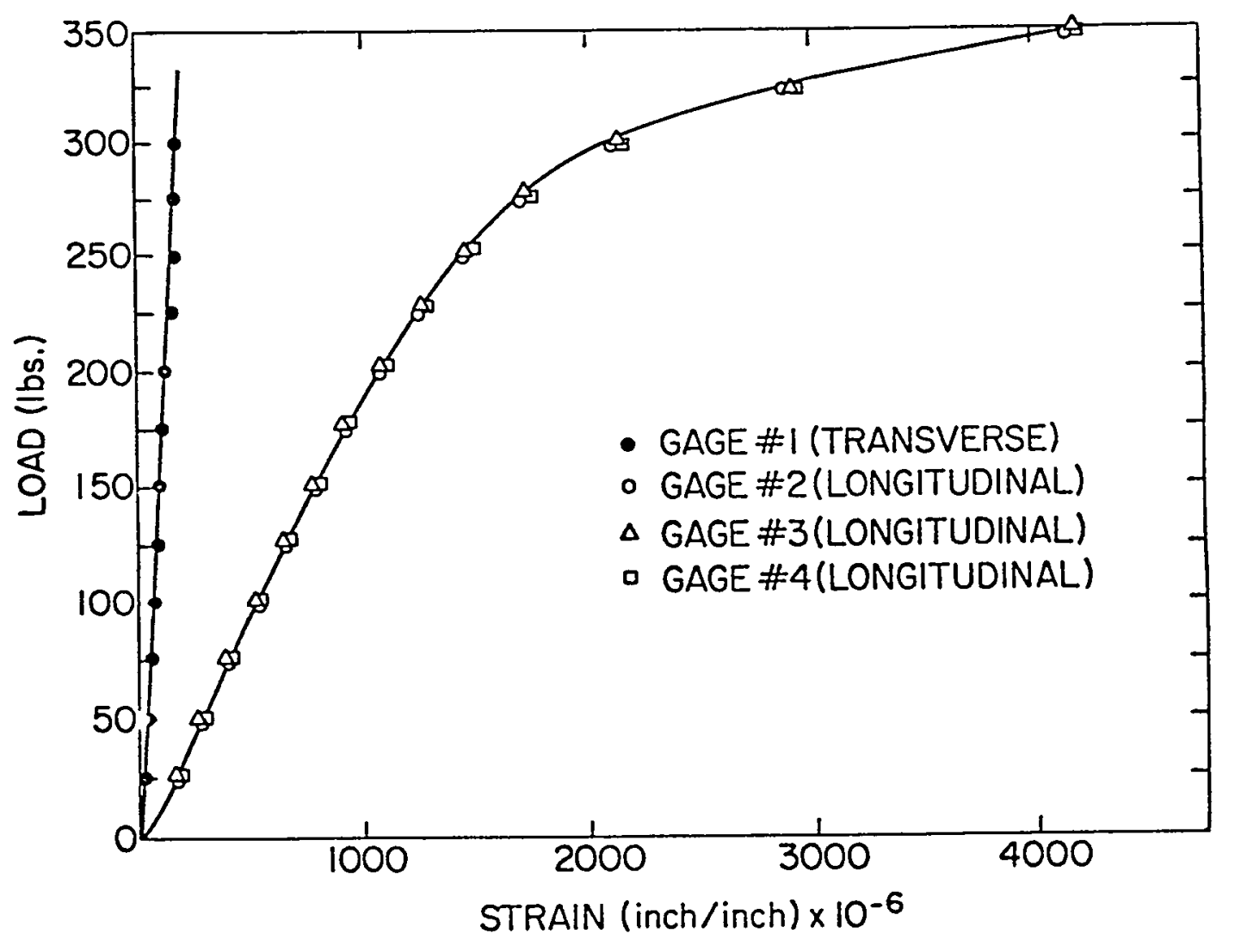

Figure 13 Load vs in-situ strain at the apex of a Type 316L stainless steel C-ring specimen. 
Table 12 Stress-strain properties of eight alloys as obtained from Instron machine tests on smooth C-ring specimens.

\begin{tabular}{|c|c|c|c|c|}
\hline A11oy & $\begin{array}{l}\text { Load at } 100 \% \\
\text { Elastic Limit } \\
(\mathrm{kg})\end{array}$ & $\begin{array}{l}\text { Deflection at } \\
100 \% \text { Elastic } \\
\text { Limit (cm) }\end{array}$ & $\begin{array}{l}\text { Deflection at } \\
90 \% \text { Elastic } \\
\text { Limit (cm) }\end{array}$ & $\begin{array}{c}\text { Longitudinal } \\
\text { Strain at } \\
\text { Elastic Limit } \\
\left(10^{-6}\right)\end{array}$ \\
\hline $\begin{array}{l}\text { Type 304L SS } \\
\text { (as-received) }\end{array}$ & 102.0 & 0.0254 & 0.0229 & 1564 \\
\hline $\begin{array}{l}\text { Type 304L sS } \\
\text { (sensitized) }\end{array}$ & 90.7 & 0.0178 & 0.0160 & 1339 \\
\hline $\begin{array}{l}\text { Type 316L SS } \\
\text { (as-received) }\end{array}$ & 124.5 & 0.0356 & 0.0320 & 1730 \\
\hline $\begin{array}{l}\text { Type 316L SS } \\
\text { (sensitized) }\end{array}$ & 113.4 & 0.0267 & 0.0241 & 1517 \\
\hline $\begin{array}{l}\text { Type } 321 \text { sS } \\
\text { (as-received) }\end{array}$ & 79.4 & 0.0163 & 0.0147 & 1200 \\
\hline $\begin{array}{l}\text { Type } 321 \text { ss } \\
\text { (sensitized) }\end{array}$ & 90.7 & 0.0178 & 0.0160 & 1198 \\
\hline $\begin{array}{l}\text { Incoloy } 825 \\
\text { (as-received) }\end{array}$ & 170.1 & 0.0394 & 0.0356 & 2770 \\
\hline $\begin{array}{l}\text { Incoloy } 825 \\
\text { (sensitized) }\end{array}$ & 283.5 & 0.0610 & 0.0549 & 3707 \\
\hline
\end{tabular}

Is shown in Figure 13 for as-received Type 316L stainless steel. The average value of three longitudinal strains corresponding to the elastic limit is given in Table 12.

\subsubsection{Tuff}

Topopah Spring tuff was supplied by Wards Natural Science Establishment, Inc. from a surface outcrop of the Paintbrush tuff formation, southern Fran Ridge, between the J-13 we11 and eastern Yucca Mountain. The approximate geographical location of the site from where specimens were obtained is $116^{\circ} 25^{\prime}$ west and $36^{\circ} 50^{\prime}$ north. 
The mineral composition of the rock specimens, as determined by Globo de Plomo Enterprises* using a Kevex energy-dispersive X-ray spectrometer is given in Table 13. Aluminum is the lightest element which could be determined quantitatively. The results are normalized to $\mathrm{SiO}_{2}$ whose absolute concentration was not determined. As was clear from visible observation, the rock specimens had varying appearance and, hence, also varying composition from rock to rock. Results in Table 13 represent a typical composition. A brief geochemical description of the tuff given by Globo de Plomo Enterprises is presented below:

"The rock is a welded vitric tuff of rhyolite composition composed of flattened glass fragments kneaded into a streaky fabric. Welding has not been sufficient to blur fragment boundaries. The fragments carry scattered phenocrysts of sanidine with less plagioclase and oxidized biotite. Traces of augite and oxyhornblende were observed in addition to accessory magnetite.

Table 13 Geochemical analysis of Topopah Spring tuff (values in ppm unless percent is specified).

\begin{tabular}{|l|c|}
\hline & \\
Constituent & Concentration \\
\hline $\mathrm{Al}_{2}{ }^{\mathrm{O}} 3$ & $13.1 \%$ \\
$\mathrm{~K}_{2} \mathrm{O}^{2}$ & $4.52 \%$ \\
$\mathrm{CaO}$ & $2.21 \%$ \\
$\mathrm{TiO}{ }_{2}$ & $0.38 \%$ \\
$\mathrm{MnO}$ & $0.07 \%$ \\
$\mathrm{Fe}_{2} \mathrm{O}_{3}$ & $1.83 \%$ \\
$\mathrm{Cu}$ & 17 \\
$\mathrm{Zn}$ & 35 \\
$\mathrm{As}$ & 22 \\
$\mathrm{Th}$ & 18 \\
$\mathrm{Rb}$ & 116 \\
$\mathrm{Sr}$ & 109 \\
$\mathrm{Y}$ & 17 \\
$\mathrm{Zr}$ & 482 \\
$\mathrm{Nb}$ & 13 \\
$\mathrm{Sn}$ & 15 \\
$\mathrm{Ba}$ & 314 \\
$\mathrm{La}$ & 62 \\
$\mathrm{Ce}$ & 83 \\
\hline
\end{tabular}

*P. 0. Box 872, Douglas, Arizona. 
other accessories found near magnetite and mafites include zircon, allanite, and monazite.

"All of the glass domains have just begun to devitrify, producing orthoclase, quartz, and iron oxides. Tridymite lines collapsed voids and has formed in certain frothy glasses instead of quartz. Some larger voids are lined with chalcedony, then tridymite, then iron oxides, and are infilled with caliche-like calcite.

"A polished section reveals that accessory magnetite grains are penetrated and about half replaced by tablets of hematite. Rutile was also observed.

"Phenocrysts comprise about $20 \%$ of the rock by volume and a breakdown is: plagioclase $30 \%$, biotite $5 \%$, augite $2 \%$, magnetite $2 \%$, oxyhornblende $1 \%$, sanidine $60 \%$. Matrix components are too fine grained and intimately intergrown to estimate."

The as-supplied tuff specimens were too large to be used in the corrosion tests. Therefore, they were crushed into small pieces which were then sieved to separate them into two sizes, viz. coarse (0.25 in.-0.50 in.) and fine (0.187 in.-0.250 in.). In a preliminary test to estimate the solution chemistry, crushed tuff of a finer size ( 0.0165 in. -0.187 in.) was used.

\subsubsection{Preparation of Synthetic Groundwater}

In the absence of available information on the composition of groundwater which will come in contact with the waste package in tuff, groundwater from the J-13 well (which is located below the repository horizon) has been designated as the reference test solution (UCRL-89988, 1983). A chemical analysis of reference J-13 groundwater as given in Table 8 has been specified by DOE subcontractors (UCRL-89988, 1983) but there is no procedure given for its preparation in the laboratory. The J-13 water used by NNWSI is obtained from the actual site rather than prepared artificially. Therefore, a solution preparation procedure was developed at BNL.

Fourteen reagents were selected such that their solution in water would give ionic concentrations very close to that found in reference $J-13$ groundwater. The amount of chemical compounds added to distilled water to make 20 liters of synthetic $J-13$ water is given in Table 14. Initially, there was a problem in dissolving the required amount of silicic acid. With some trial and error, and considering the higher solubility of silica at higher temperature and $\mathrm{pH}$, this problem was resolved by first adding $\mathrm{NaHCO}_{3}$ to distilled water, heating it to near boiling and then adding silicic acid; other compounds were added subsequent $1 \mathrm{y}$.

As mentioned above, groundwater coming in contact with a container can have much higher ionic concentrations than in $\mathrm{J}-13$ groundwater. This would happen when salts, precipitated during initial evaporation of groundwater, are redissolved as new cooler groundwater arrives at a later time. Since there are no estimates available for this groundwater concentration effect, we have arbitrarily assumed a concentration factor of ten. However, for a ten-timesconcentrated solution, some of the species (e.g. $\mathrm{SiO}_{2}$, divalent cation) may be 
Table 14 Amount of chemical compounds used in preparing 20 liters of synthetic $\mathrm{J}-13$ water (mg).

\begin{tabular}{|l|r|}
\hline \multicolumn{1}{|c|}{ Reagent } & Wt. (mg) \\
\hline $\mathrm{NaHCO}_{3}$ & 3292 \\
$\mathrm{KOH}$ & 140 \\
$\mathrm{SiO}_{2} \cdot \mathrm{xH}_{2} \mathrm{O}\left(1.87 \% \mathrm{H}_{2} \mathrm{O}\right)$ & 1243 \\
$\mathrm{CaCl}_{2}(460 \mathrm{mg} \mathrm{CaCO}$ & 232 \\
$\left.\mathrm{CaSO}_{4}+440 \mathrm{mg} \mathrm{H}{ }_{2} \mathrm{SO}_{4}\right)$ & 624 \\
$\mathrm{Ca}\left(\mathrm{NO}_{3}\right)_{2}$ & 48 \\
$\mathrm{Mg}\left(\mathrm{NO}_{3}\right)_{2} \cdot 6 \mathrm{H}_{2} \mathrm{O}$ & 256 \\
$\mathrm{MgF}_{2}(46.6 \mathrm{mg} \mathrm{MgO}+96.5 \mathrm{mg} \mathrm{HF}-48 \%)$ & 72 \\
$\mathrm{LiNO}_{3}$ & 10 \\
$\mathrm{Sr}\left(\mathrm{NO}_{3}\right)_{2}$ & 2.4 \\
$\mathrm{BaCl}_{2} \cdot 2 \mathrm{H}_{2} \mathrm{O}$ & 1.8 \\
$\mathrm{Fe}\left(\mathrm{NO}_{3}\right)_{3} \cdot 9 \mathrm{H}_{2} \mathrm{O}$ & 7.2 \\
$\mathrm{H}_{3} \mathrm{PO}_{4}(85 \%)$ & 2.8 \\
$\mathrm{Al}\left(\mathrm{NO}_{3}\right)_{3} \cdot 9 \mathrm{H}_{2} \mathrm{O}$ & 13.9 \\
\hline
\end{tabular}

beyond their saturation limit at room temperature. However, the solubility would be increased at the $100^{\circ} \mathrm{C}$ test temperature used. The equilibrium composition of ten-times concentrated $\mathrm{J}-13$ water at $100^{\circ} \mathrm{C}$ is difficult to determine. Therefore, we have added ten-times the quantity of salts needed for synthetic $J-13$ water and allowed the salts (including those insoluble at room temperature) to equilibrate at $100^{\circ} \mathrm{C}$. Such a liquid, which is not clear at room temperature, provides ten-times higher ionic concentrations of the soluble species and saturation concentrations of insoluble species at $100^{\circ} \mathrm{C}$. In the actual tests to be performed, the solution composition will be further modified due to the interaction between water and crushed tuff. Thus, posttest analysis of the solutions was carried out.

\subsection{Apparatus}

The tests were conducted in six identical test vessels (corresponding to six different test conditions). One is shown in Figure 14. In each unit, C-ring specimens along with crushed rock and test solution were stacked in a 4-1iter Pyrex vessel. Approximately $6 / 7$ of the vessel height was enclosed within an electrical furnace. The lid of the vessel has space for four connections, two of which were kept closed. A thermometer and a cold water condenser were placed in the other two receptacles. Flowing cold water condensed the steam to water which dripped back into the vessel. The top of the condenser was open to the atmosphere so that some air was present during test.

To measure the in-situ $\mathrm{pH}$ of the solution during a test it became necessary to have easy access to the solution. For this purpose, a 15-mm $0 . d$. quartz bulb with many small holes along its length was placed in the center of 


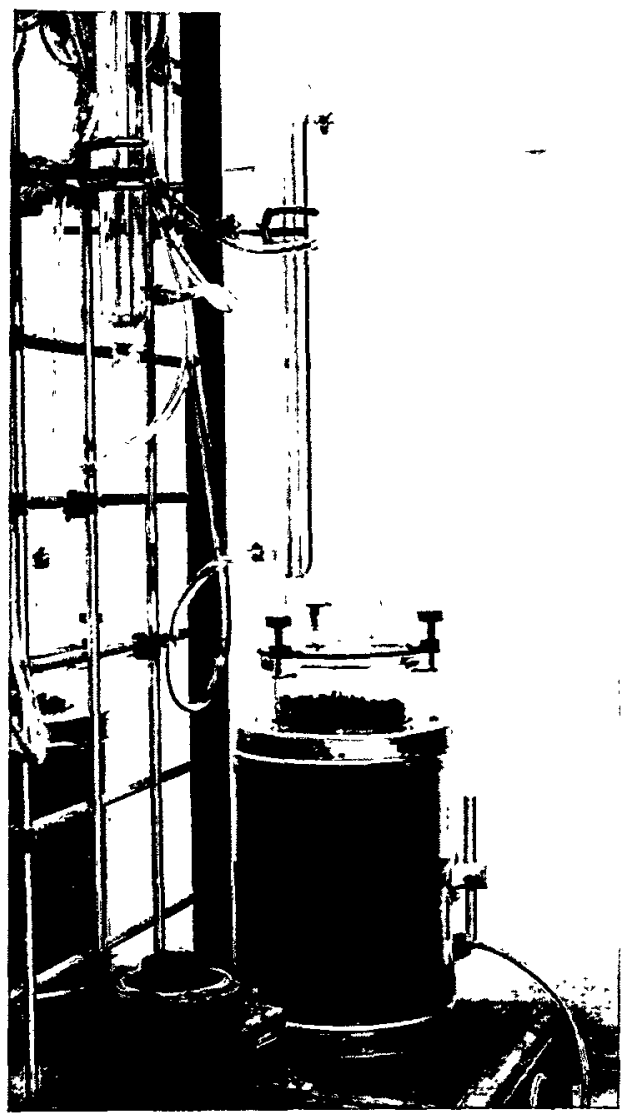

Figure 14 c-ring stress corrosion cracking test apparatus.

the vessel. A microcombination $\mathrm{pH}$ probe (MI-410, Microelectrodes, Inc.) could be inserted in this tube from the top of the vessel and the solution $\mathrm{pH}$ measured with a standard $\mathrm{pH}$ meter.

\subsection{Test Procedure}

Each specimen was marked by small indentations on its side to identify the alloy. An additional mark was indented on those specimens which were sensitized. Triplicate samples were used for each alloy under each test condition. The specimens were stacked within the crushed tuff in two layers at two levels in a test vessel (Figure 15). In all, six test vessels were used, two for each time period (3-month, 6-month and 12-month), one using J-13 water, the other using ten-times-concentrated J-13 water. The samples at the lower level were submerged in solution whereas those at the upper level were surrounded by crushed tuff, air, and steam. Note that the C-ring specimens were surrounded only by fine size crushed tuff. Before filling the vessel with tuff, the $\mathrm{pH}$ tube was placed in the center of the vessel. Care was exercised so that no specimens touched. 


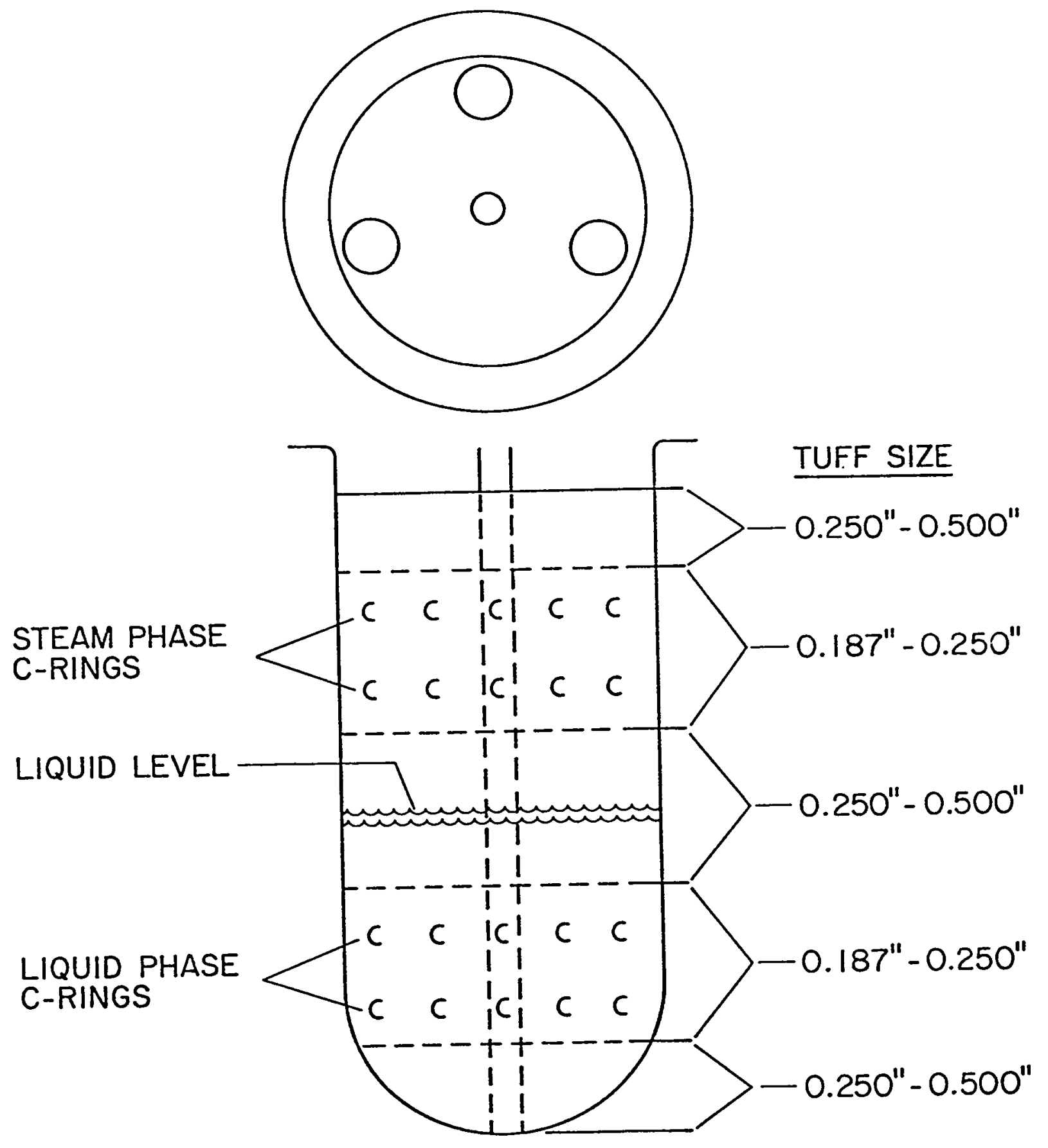

Figure 15 Schematic of the specimen arrangement in a test vessel. 
After packing crushed rock around the specimens, approximately $1100 \mathrm{cc}$ of test solution was added to bring the liquid level to half the depth of the vessel. Within a short time the liquid level became slightly lower presumably due to absorption by the rocks, but the lower level specimens were always well submerged in solution as confirmed by checking the water level every week. After putting the lid with a thermometer and condenser in place, the vessel was slowly heated to bring the solution to boiling. The furnace power was adjusted so that the water from the condenser dripped at a rate of 5-10 drops per minute.

The $\mathrm{pH}$ of the test solutions was measured every month. At the end of a test, $50 \mathrm{~mL}$ of solution was withdrawn from the vessel and mixed with $50 \mathrm{~mL}$ of boiling distilled water. The solution was then cooled to room temperature and filtered through a Whatman 42 paper. Another $100 \mathrm{~mL}$ of test solution was cooled to room temperature and filtered without dilution. The chemical compositions of the test solutions were determined using standard analytical techniques. A comparison of the chemical analyses of the dilute and the normal strength test solutions would indicate if any precipitation occurs during cooling to room temperature. After the solution samples were collected, the test vessel was cooled to room temperature and the C-ring specimens visually examined for cracks. Representative specimens were cleaned ultrasonically in distilled water and then examined under an optical or scanning electron microscope. The cross sections of several specimens cut perpendicularly to the notch through the center of the bolt holes were examined for any microscopic cracks.

To determine the possible range of compositions of repository groundwater, another test was carried out in a test vessel similar to the ones used In the c-ring tests. It was filled with crushed tuff $(0.165$ to 0.187 inch size) and distilled water, and then maintained under boiling water conditions. The solution was drained from the vessel and fresh distilled water was added to the vessel periodically. The solutions were analyzed using standard techniques.

\subsection{Oxygen Measurements in the Steam Phase and in the Solution}

Stress corrosion cracking of stainless steels is known to be strongly dependent on the oxygen concentration in the test environment, a1though there is no simple relationship between the two. In the present tests, oxygen concentration is fixed by the test conditions. To determine its value in solution and steam phases the following experiments were carried out:

(a) Oxygen content in steam phase: as shown in Figure 15, the top of the test vessel is open to atmosphere via a 2-foot long water-cooled condenser tube. The steam produced from the boiling solution first fills up the upper half of the vessel and then condenses into water which drips down from the condenser. It is, therefore, believed that there is a concentration gradient of air along the condenser whereas most of the vessel volume above the liquid level is filled with steam. Most likely, a part of the oxygen present in the air-steam mixture will be consumed in the corrosion process. To determine if 
there is a significant consumption of oxygen, a glass adapter was constructed to collect an air-steam sample. The adapter permitted the collection of the gas specimen from within the crushed tuff and near the C-rings, into a glass bu1b. After the adapter was connected to the vessel the system was allowed to equilibrate for three days. Before collecting the final gas sample, the bulb was evacuated and purged three times with the air-steam mixture. Since the glass bulb was at room temperature, the steam part of the air-steam mixture readily condensed into water and the bulb pressure decreased. A sample of this low pressure gas was taken from the bulb with a Pressure-Lok syringe and analyzed with a Perkin Elmer 3920 gas chromatograph. The analysis of the test sample was compared with that of a standard gas containing $20 \% \mathrm{O}_{2}, 79 \% \mathrm{~N}_{2}$ and $1 \% \mathrm{CO}_{2}$, and an air sample collected from near the vessel.

Since the pressure within the bulb has not been determined, it is not possible to know the absolute concentration of oxygen in the steam phase. However, by comparing the relative heights of the oxygen and nitrogen peaks in the chromatograph of the test sample, standard gas, and air, relative loss of oxygen such as by corrosion can be estimated. The results given below are based on an average of 3 or 4 analyses. The ratio of peak heights for $\mathrm{O}_{2}$ and $\mathrm{N}_{2}$ (not their concentrations) in the test specimen, the standard gas and the laboratory air were determined to be $0.494,0.562$, and 0.560 , respectively. These results suggest that there is appreciable consumption of oxygen in the vessel either by metal corrosion or some form of interaction with tuff.

(b) Oxygen content in solution: the concentration of dissolved oxygen in the test solutions has been measured using an Altex Model 0260 oxygen analyzer. The use of the electrode in this analyzer is limited to near room temperature. Therefore, the test solution must be cooled to ambient temperature without coming in contact with air which would alter the oxygen concentration. Accordingly, approximately $15 \mathrm{~mL}$ of the test solution was collected in a syringe from the central tube of the vessel. The solution was allowed to cool to room temperature and then transferred into a $10 \mathrm{~mL}$ beaker, and placed in a glove box filled with argon. The oxygen electrode was first calibrated to read $8.4 \mathrm{ppm}$ dissolved oxygen in air-saturated distilled water at $25^{\circ} \mathrm{C}$. The concentration of dissolved oxygen in $\mathrm{J}-13$ and $10 \mathrm{xJ}-13$ solutions was determined to be 2.8 and $2.7 \mathrm{ppm}$, respectively. Repeating the measurements on a second sample of $\mathrm{J}-13$ solution indicated a reproducibility within $\pm 0.1 \mathrm{ppm}$.

The Henry's constant at 25 and $100^{\circ} \mathrm{C}$ is $4.38 \times 10^{4}$ and $7.01 \times 10^{4}$, respectively (Perry's Chemical Engineer's Handbook). Therefore, the equilibrium solubility of $\mathrm{O}_{2}$ (from air) in water should be $5.25 \mathrm{ppm}$. The observed concentration of dissolved oxygen in the test solutions is lower than this value, perhaps due to a different water chemistry or lower partial pressure of $\mathrm{O}_{2}$. 


\section{C-RING TEST RESULTS}

Visual examination of the surfaces of c-ring specimens after testing for three, six and twelve months in boiling $\mathrm{J}-13$ and ten-times-concentrated $\mathrm{J}-13$ groundwater, and in the steam phase above these solutions showed no macrocracks. To check the presence of microcracks, several specimens were sectioned perpendicularly to the notch and polished. These were examined under optical and scanning electron microscopes. The results for each of the material are shown in the following sections.

\subsection{Type 304L Stainless Steel}

Two as-machined, untested specimens which were polished and examined under the SEM showed no evidence of crack initiation at the V-notch or on adjacent surfaces. Any microcracks detected after testing would, therefore, be nucleated as a consequence of a corrosion mechanism.

Table 15 gives a summary of the stress corrosion cracking behavior of Type 304L stainless steel under various test conditions. Also given in the table is the maximum length of the microcrack observed for each condition. Al1 tested specimens could not be examined with the SEM due to lack of time and funding. Also, the specimens which were examined did not show consistent behavior since the initiation of a crack or its length could vary at different locations on the specimen. The results in Table 15 show that there is no trend in the stress corrosion cracking behavior with respect to the specimen condition or the experimental conditions. The time dependence of the cracking behavior can be confirmed only after examining more specimens. The maximum crack lengths observed in six-month as well as twelve-month specimens, however, are of the same order of magnitude.

Figure 16 shows the outer edge of an as-received Type 304L stainless steel tested in the steam/air phase over $\mathrm{J}-13$ groundwater for three-months. A forked crack has formed which is propagating along a grain boundary. The crack length measured from the outer edge is $18 \mu$. Two other sensitized specimens tested in steam/air phase above ten-times-concentrated J-13 water did not show any cracks.

Figures 17 to 20 show specimens tested for six months under various conditions. A crack in a sensitized specimen tested in the air/steam is shown in Figure 17. The path of the crack cannot be confirmed from the SEM micrograph since the grain boundaries could not be revealed by etching. Figure 18 shows what appears to be.intergranular attack in an as-received specimen tested in boiling ten-times-concentrated $J-13$ solution. The depth of attack is $27 \mu$. Figure 19 shows several cracks initiating at the notch root of a sensitized specimen tested in boiling ten-times-concentrated J-13 water. It should be noted that the notch root has undergone cold working during specimen fabrication which apparently makes it more susceptible to stress corrosion cracking. Figure 20 shows intergranular attack on an as-received specimen tested in boiling $\mathrm{J}-13$ water. 
Table 15 Stress corrosion cracking tests for Type 304L stainless steel.

\begin{tabular}{|c|c|c|c|c|c|}
\hline \multirow{2}{*}{$\begin{array}{r}\text { Test Time } \\
\text { (months) }\end{array}$} & \multirow{2}{*}{$\begin{array}{l}\text { Specimen } \\
\text { Conditions }\end{array}$} & \multicolumn{2}{|c|}{ Steam Test } & \multicolumn{2}{|c|}{ Water Test } \\
\hline & & $\mathrm{J}-13$ Water $^{\mathrm{a}}$ & $10 \times \mathrm{J}-13$ Water & J-13 Water & $10 \times \mathrm{J}-13$ Water $^{\mathrm{a}}$ \\
\hline \multirow[t]{2}{*}{3} & As Received & $\begin{array}{l}2 / 2^{b} \\
28 \mu^{c}\end{array}$ & N.E. & N.E. & N.E. \\
\hline & Sensitized & $N \cdot E \cdot d$ & $0 / 2$ & N.E. & N.E. \\
\hline \multirow{2}{*}{6} & As Received & $\begin{array}{l}2 / 2 \\
13 \mu\end{array}$ & $\begin{array}{l}2 / 2 \\
27 \mu\end{array}$ & $\begin{array}{l}1 / 2 \\
28 \mu\end{array}$ & $\begin{array}{l}1 / 2 \\
27 \mu\end{array}$ \\
\hline & Sensitized & $0 / 2$ & $\begin{array}{l}2 / 2 \\
19 \mu\end{array}$ & $0 / 1$ & $\begin{array}{c}1 / 2 \\
16 \mu(\operatorname{not} c h)\end{array}$ \\
\hline \multirow{2}{*}{12} & As Received & $\begin{array}{l}1 / 2 \\
7 \mu\end{array}$ & $0 / 2$ & $\begin{array}{l}1 / 1 \\
26 \mu\end{array}$ & $\begin{array}{l}1 / 2 \\
7 \mu\end{array}$ \\
\hline & Sensitized & $0 / 1$ & $\begin{array}{l}1 / 1 \\
26 \mu\end{array}$ & $\begin{array}{l}1 / 1 \\
43 \mu\end{array}$ & $0 / 1$ \\
\hline
\end{tabular}

a) The composition of test solution changes substantially with time. See Table 19 for detailed composition.

b) Specimens with microcracks/number of specimens examined.

c) Maximum crack length in $\mu$.

d) Not examined (N.E.). 


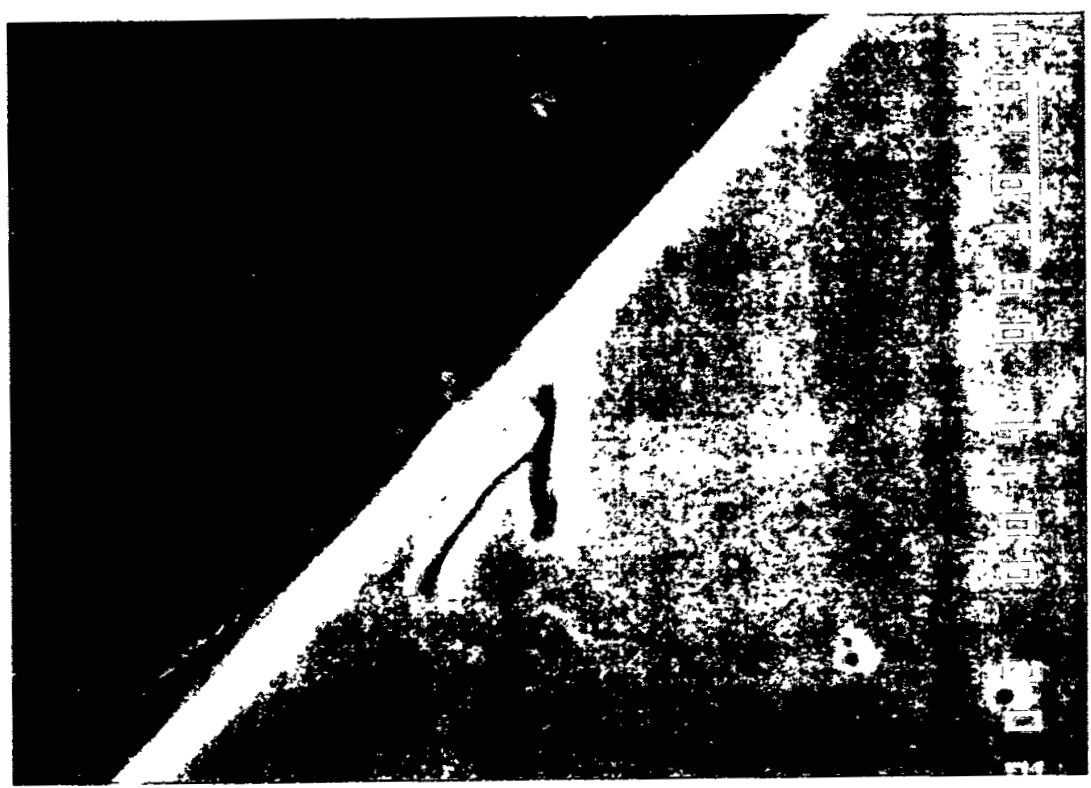

Figure 16 An SEM micrograph of part of the outer diameter of an as-received (solution annealed) Type 304L stainless steel specimen tested in steam/air phase above boiling J-13 groundwater for 3 months (x2000).

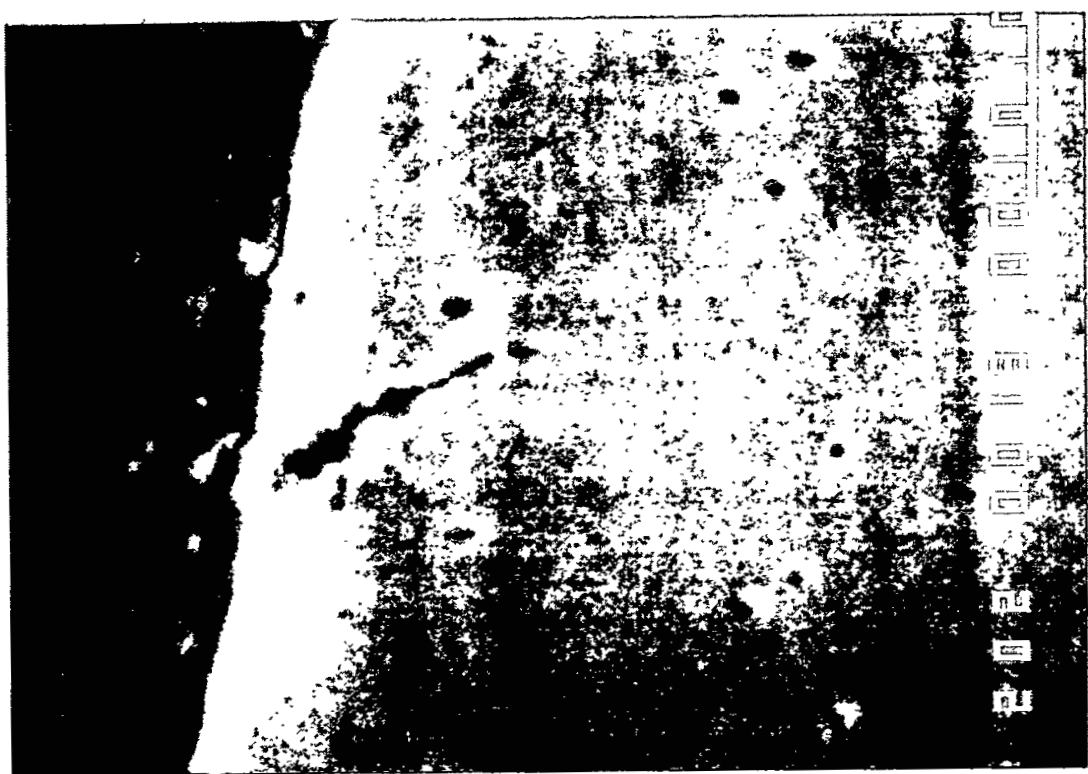

Figure 17 An SEM micrograph of part of the outer diameter of a sensitized Type 304L stainless steel specimen tested in steam/air phase above boiling $10 \mathrm{xJ}-13$ solution for 6 months ( $x 2000)$. 


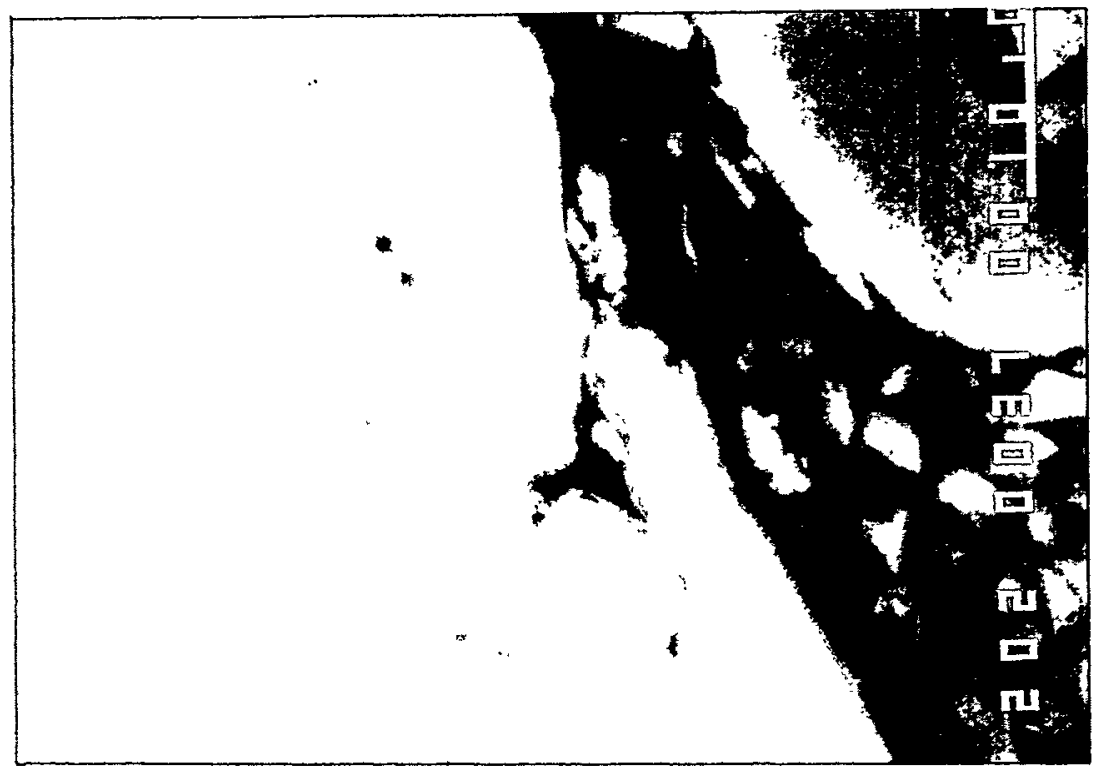

Figure 18 An SEM micrograph of part of the outer diameter of an as-received (solution annealed) Type 304L stainless steel specimen tested in boiling $10 \mathrm{xJ}-13$ solution for six months ( $x 2000)$.

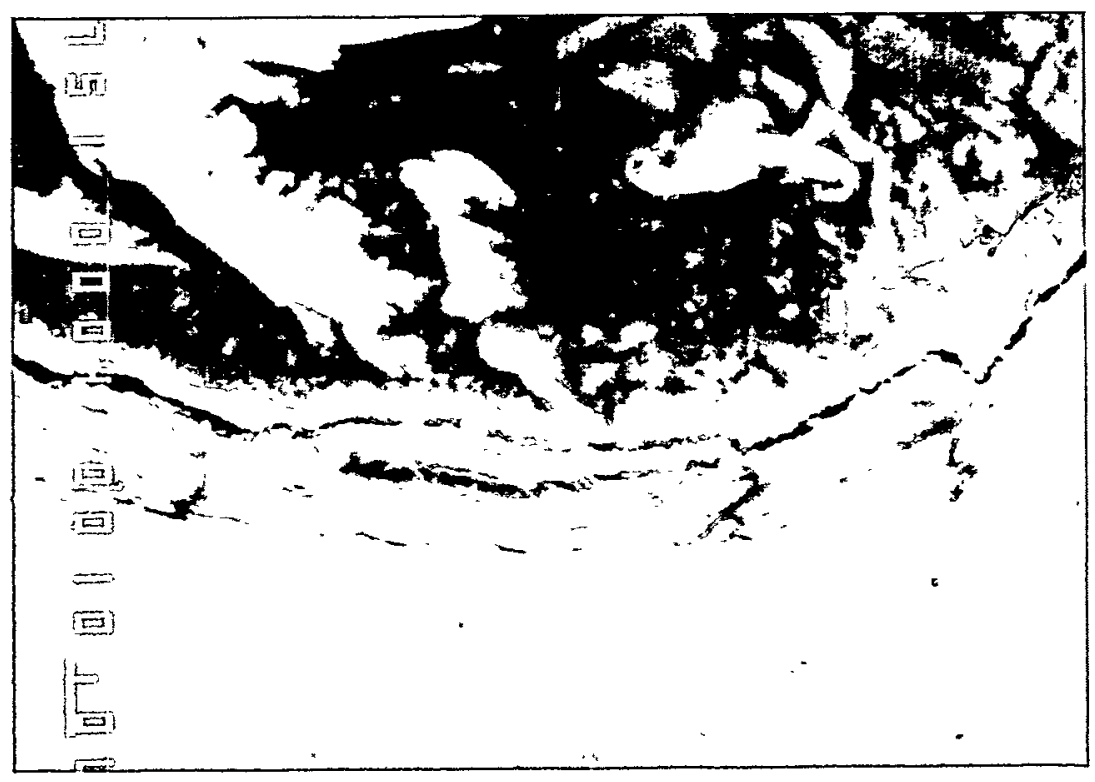

Figure 19 An SEM micrograph of part of the notch root of a sensitized Type 304L stainless steel specimen tested in boiling $10 x J-13$ solution for six months (x750). 


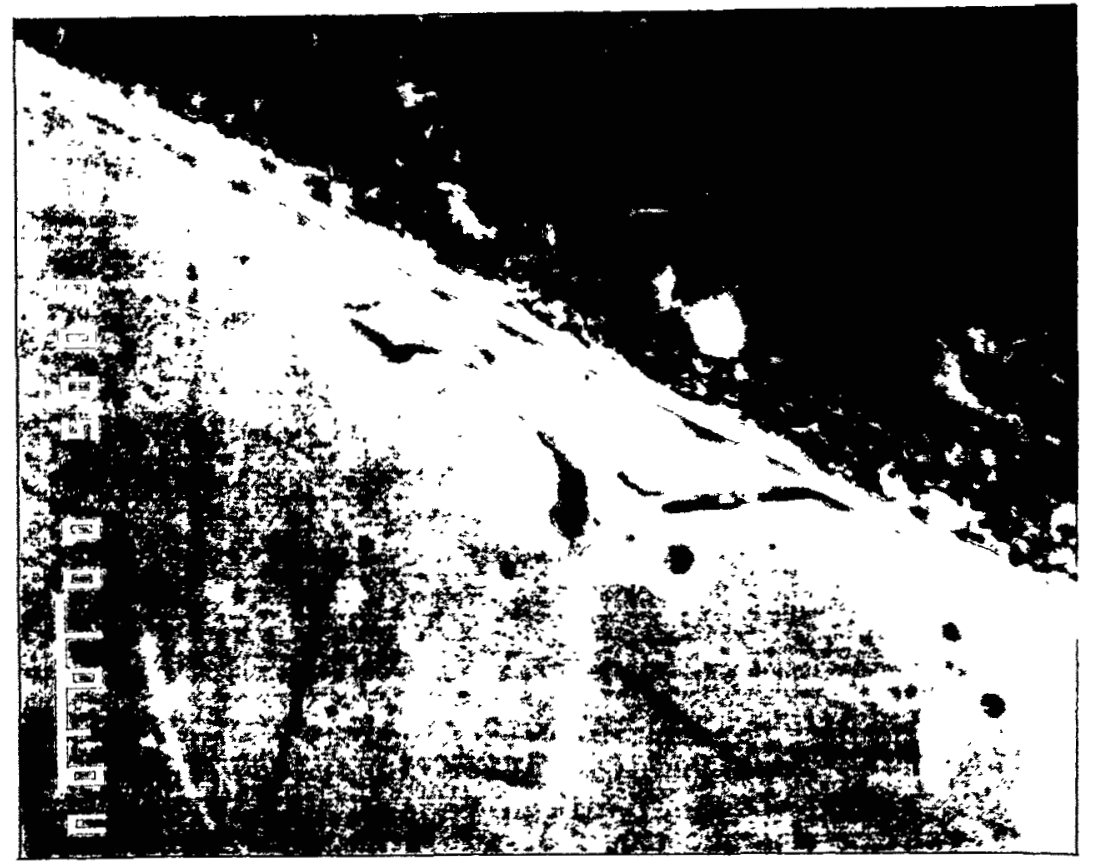

Figure 20 An SEM micrograph of part of the outer diameter of an as-received (solution annealed) Type 304L stainless steel specimen tested in boiling $\mathrm{J}-13$ solution for six months ( $\mathrm{x} 2000)$.

Figures 21 and 22 show the stress corrosion cracking behavior of Type $304 \mathrm{~L}$ stainless steel in the one year tests. An intergranular crack is clearly visible on an as-received specimen tested in boiling J-13 solution (Figure 21). Figure 22 shows an SEM micrograph of part of the surface of a sensitized specimen tested in the steam/air phase above ten-times-concentrated $\mathrm{J}-13$ solution. The crack which has a depth of $26 \mu$ is clearly propagating along a grain boundary.

For the cracked Type 304L stainless steel specimens examined under the SEM and optical microscope, only one specimen had crack initiation at the notch root, where the stress concentration is expected to be the maximum. All the remaining crack initiations were seen on the outer surfaces of the specimens. One possible explanation for this phenomenon is that cracks could be readily initiated at metal-tuff contact points, where crevice-like conditions could give rise to more aggressive environments. 


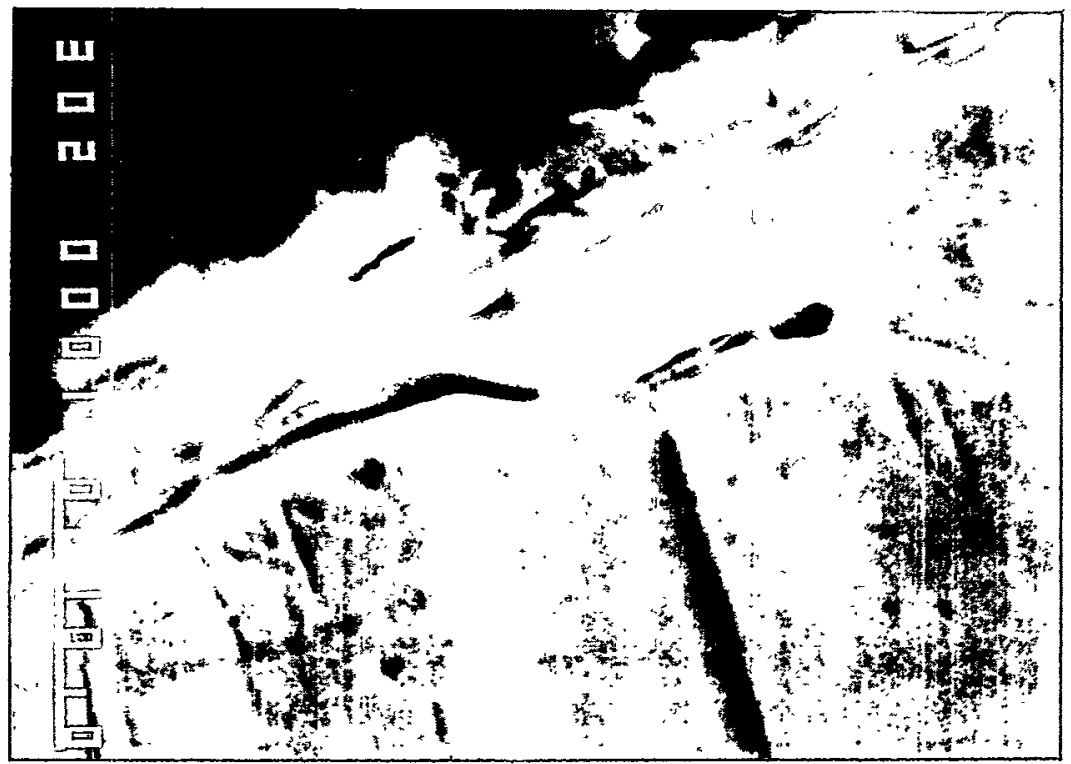

Figure 21 An SEM micrograph of part of the outer diameter of an as-received (solution annealed) Type 304L stainless steel specimen tested in boiling $\mathrm{J}-13$ solution for twelve months $(\mathrm{x} 3000)$.

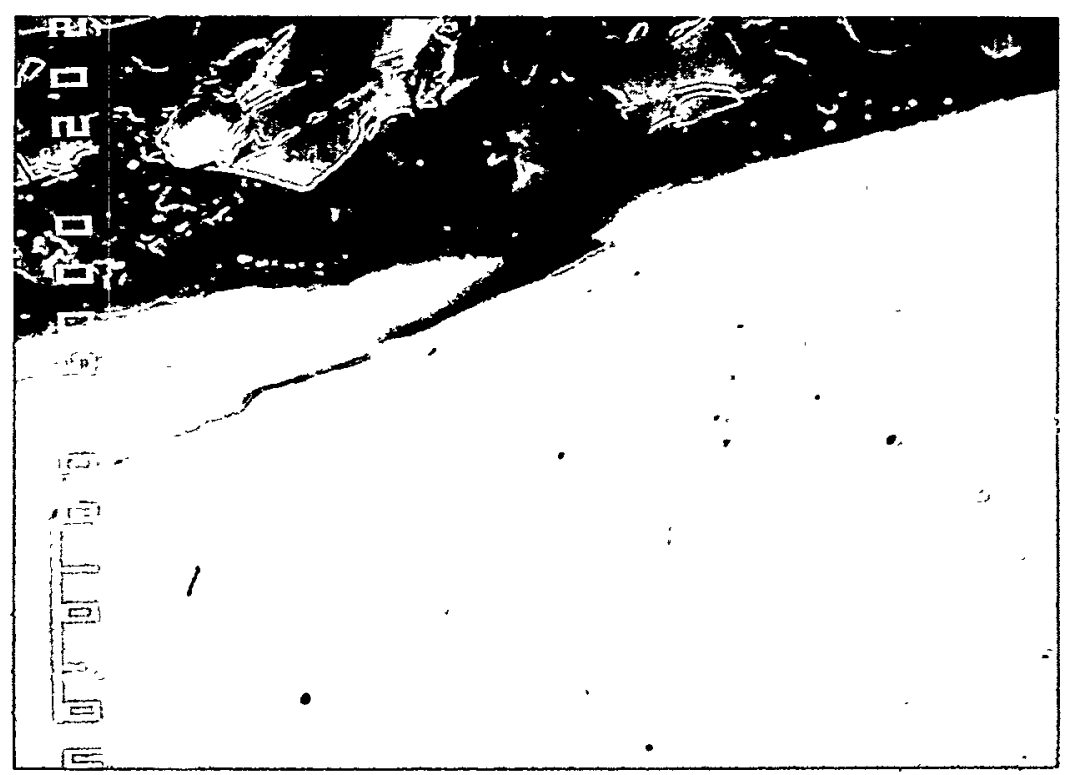

Figure 22 An SEM micrograph of part of the outer diameter of a sensitized Type 304L stainless steel specimen tested in steam/air phase above boiling $10 \mathrm{xJ}-13$ solution for twelve months (x2000). 


\section{' 5.2 Type 316L Stainless Steel}

During the course of this study it was decided to more closely check the as-machined surfaces of the test specimens to determine if surface flaws could be present prior to test. Surprisingly, minute cracks were detected in a single Type 316L stainless steel sample (Figure 23). Other Type 316L specimens did not show this effect, nor did any Type 304L, Type 321 , or Incoloy-825 as-machined samples. The cracks are, therefore, likely to have been initiated during manufacture at the mill. Because of this some of the cracks observed in Type 316L stainless steel could have been nucleated prior to test. Obviously, cracks which are present at notches, or are highly branched, would have been formed during test.

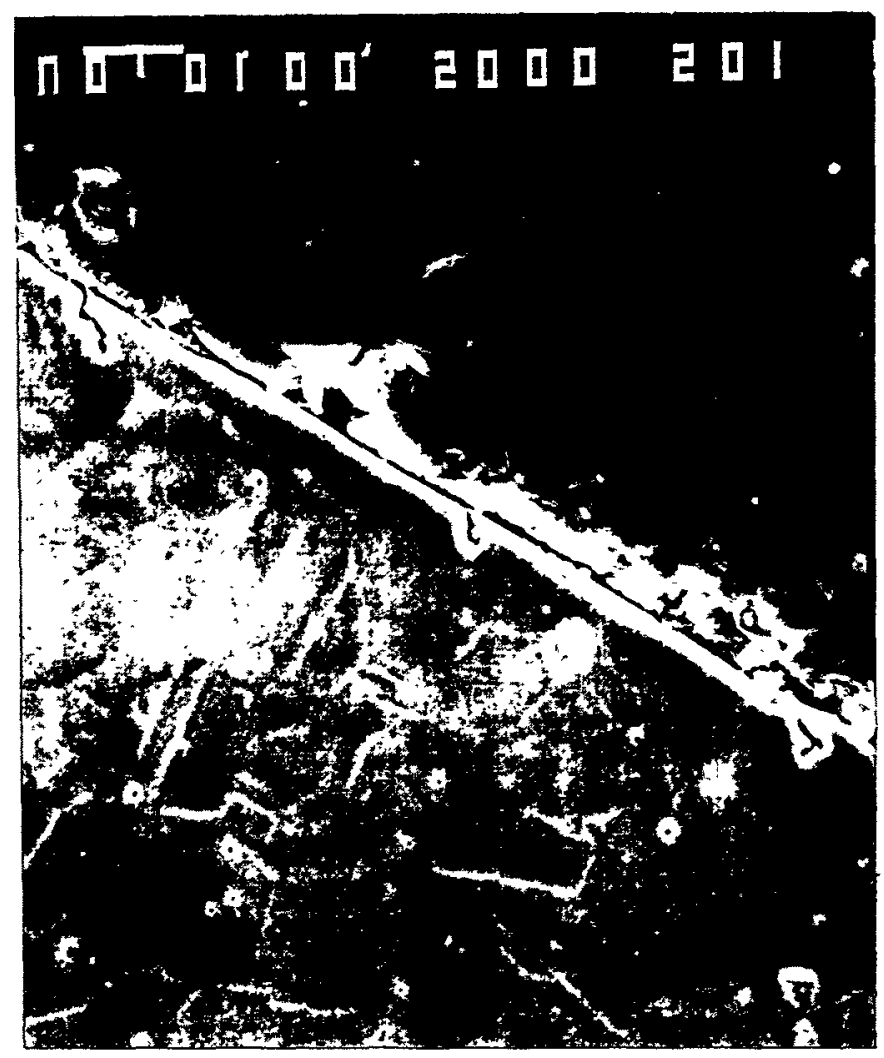

Figure 23 An SEM micrograph of part of the outer diameter of an as-received, untested Type 316L stainless steel specimen (x1000). 
For the three-month tests, specimens for two test conditions were examined. Figure 24 shows an SEM micrograph of part of the surface of a Type 316L stainless steel specimen tested in boiling J-13 water. The crack is heavily branched and seems to be advancing along a grain boundary. Figure 25 shows a crack propagating in a specimen tested in the steam/air phase above boiling ten-times-concentrated $\mathrm{J}-13$ solution. The nature and path of the cracks in both cases seem to be similar.

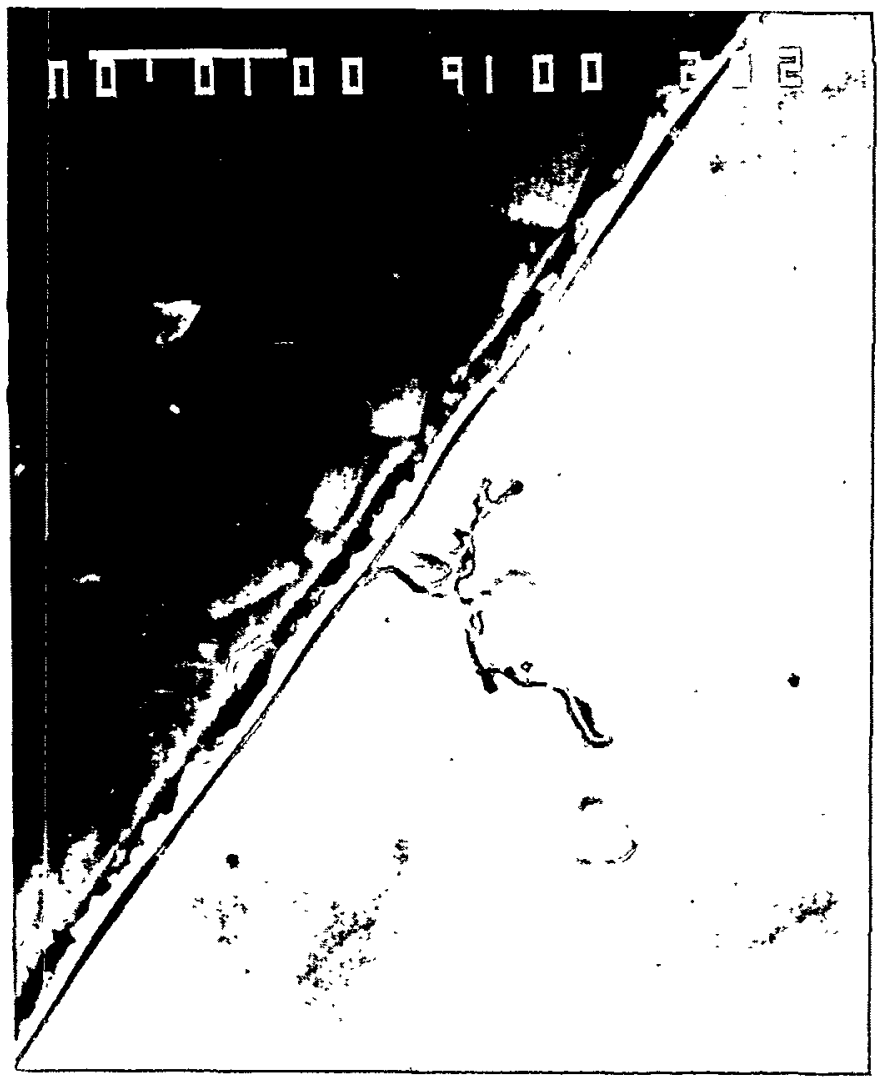

Figure 24 An SEM micrograph of part of the outer diameter of an as-received (solution annealed) Type 316L stainless steel specimen tested in boiling J-13 water for three months (x2000). 


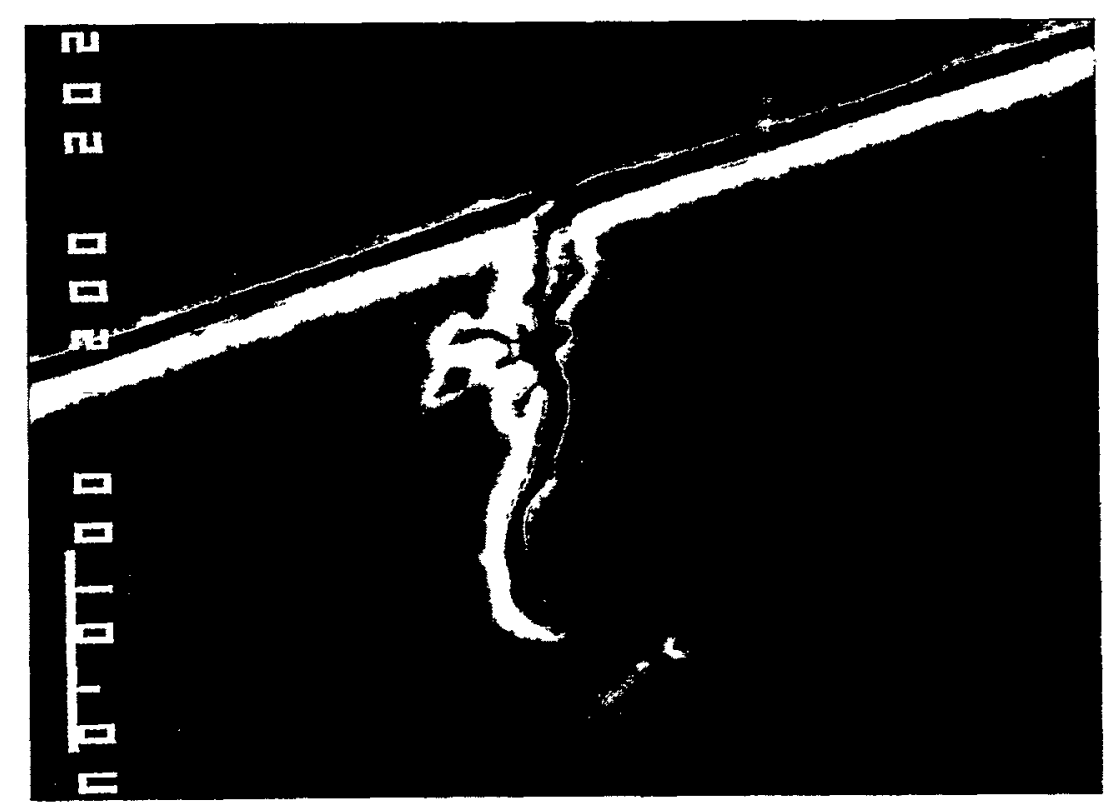

Figure 25 An SEM micrograph of part of the outer diameter of a sensitized Type $316 \mathrm{~L}$ stainless steel specimen tested in steam/ air phase above boiling $10 \times \mathrm{J}-13$ water for three months ( $\mathrm{x} 2000)$.

For the six-month tests, cracks initiated under all test conditions. Figures 26 and 27 show SEM micrographs of Type 316L stainless steel specimens tested in boiling $\mathrm{J}-13$ water. Figure 26 shows a crack initiating at the notch root which has a depth of $7 \mu$. However, the large crack shown in Figure 27 is branched and has advanced to a depth of $24 \mu$. Crack initiation at the notch root similar to that shown in Figure 26 is also found in a sensitized specimen tested in the same environment and this is shown in Figure 28.

When an as-received specimen was tested in the steam/air phase above boiling J-13 water, cracks were found at the notch root as shown in Figure 29. In the case of sensitized specimens tested under the same condition cracks were found on the surfaces of the specimens remote from the notch. For the tests conducted in ten-times-concentrated $\mathrm{J}-13$ water, the crack initiations were found at the notch root for as-received as well as sensitized specimens, and are shown in Figure 30 to 32 .

Cracks found in one-year samples are shown in Figures 33 to 35 . Figure 33 shows an SEM micrograph of part of the surface of a specimen tested in boiling J-13 water. Here, a large pit formed on the specimen and cracks are inftiated at the base of the pit. A branched crack is propagating under similar conditions in the specimen shown in Figure 34. In the tests conducted in the steam/air phase above boiling $\mathrm{J}-13$ or ten-times-concentrated several 


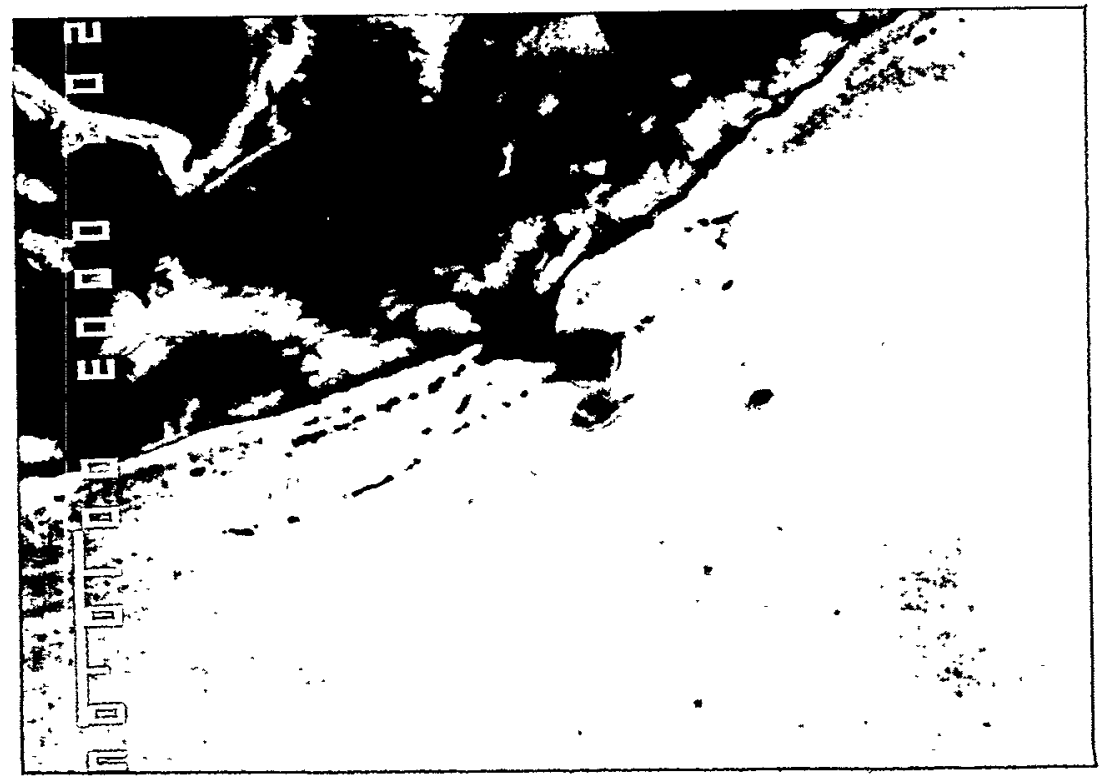

Figure 26 An SEM micrograph of part of the notch root of an as-received (solution annealed) Type 316L stainless steel specimen tested in boiling J-13 water for six months $(\mathrm{x} 2000)$.

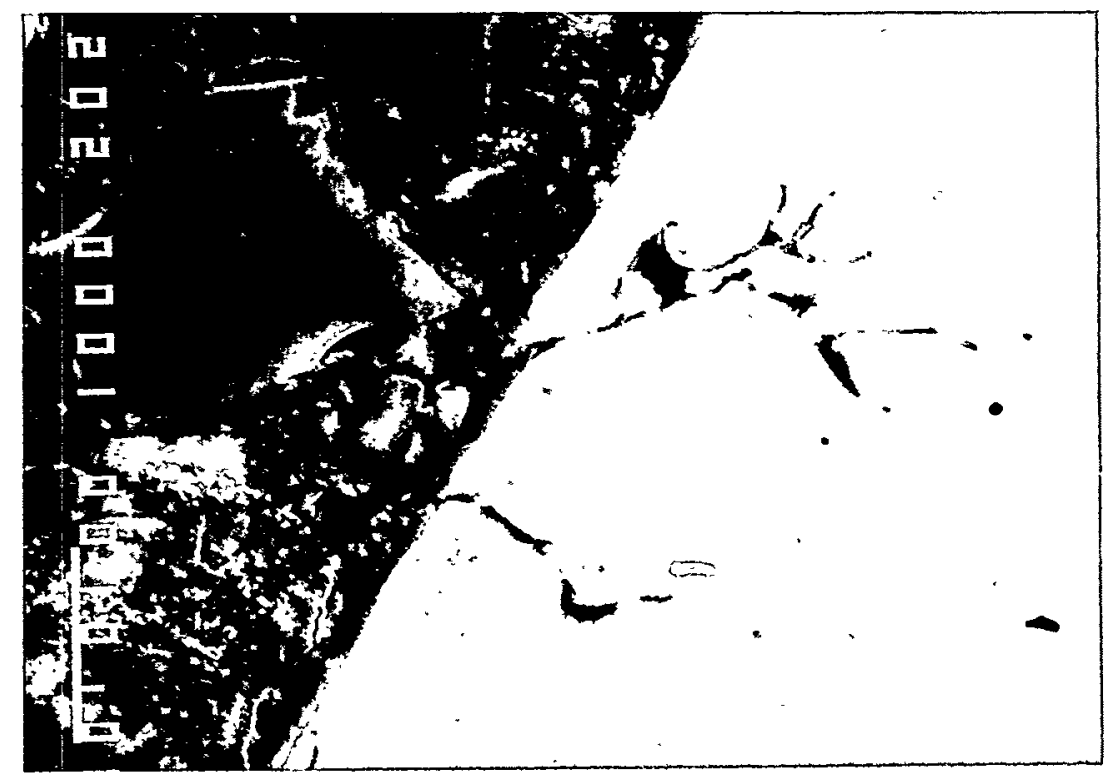

Figure 27 An SEM micrograph of part of the outer diameter of an as-received (solution annealed) Type $316 \mathrm{~L}$ stainless stee 1 specimen tested in boiling J-13 water for six months ( $x 2000)$. 
specimens have cracked. One such crack is shown in Figure 35 . In this case, it seems that small grains have been removed, possibly by the metallographic procedure, leaving an enlarged cavity adjacent to the crack.

Table 16 gives a summary of the stress corrosion cracking behavior of Type 316L stainless steel under various conditions. As in the case of Type $304 \mathrm{~L}$ stainless steel, there does not seem to be a trend in the stress corrosion cracking behavior depending on the specimen conditions or the experimental conditions. The time dependence on the cracking behavior cannot be confirmed from the current analysis of the specimens. However, the maximum crack length observed on the six month test specimens as well as the one year test specimens are of the same order of magnitude.

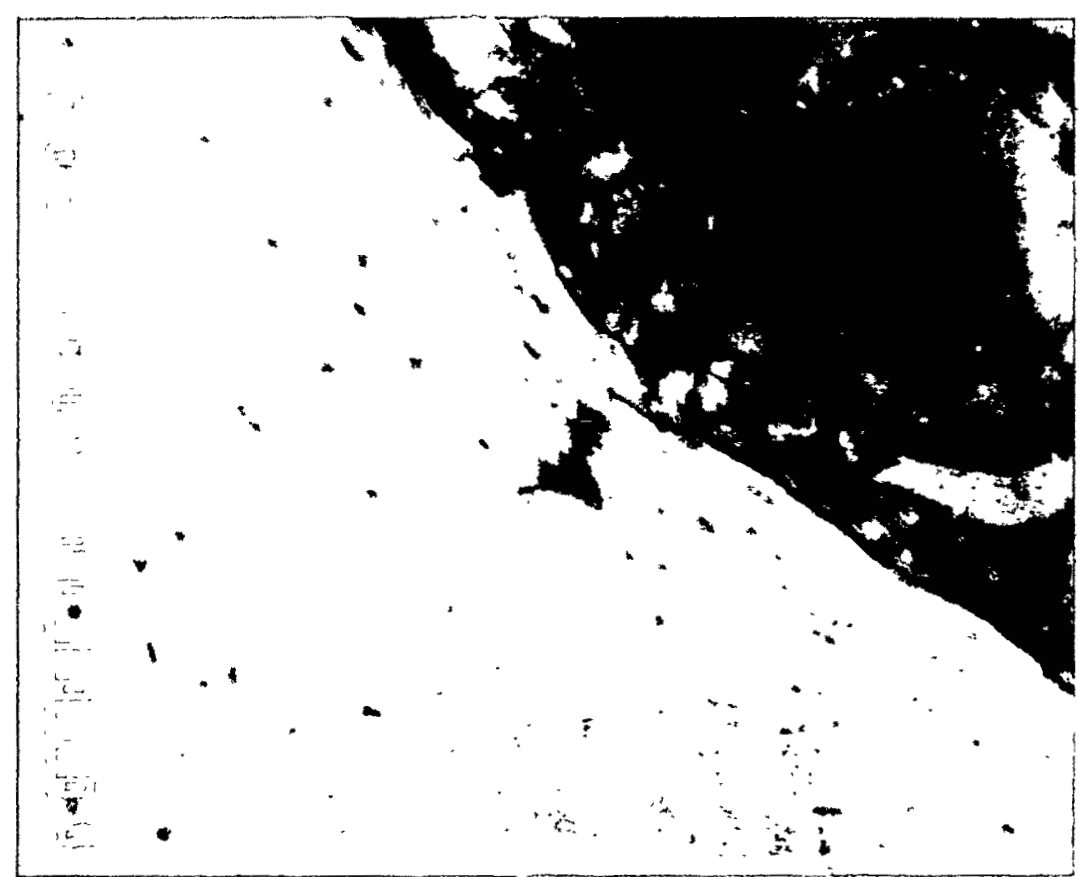

Figure 28 An SEM micrograph of part of the notch root of a sensitized Type 316L stainless steel specimen tested in boiling $\mathrm{J}-13$ water for six months $(x 2000)$. 


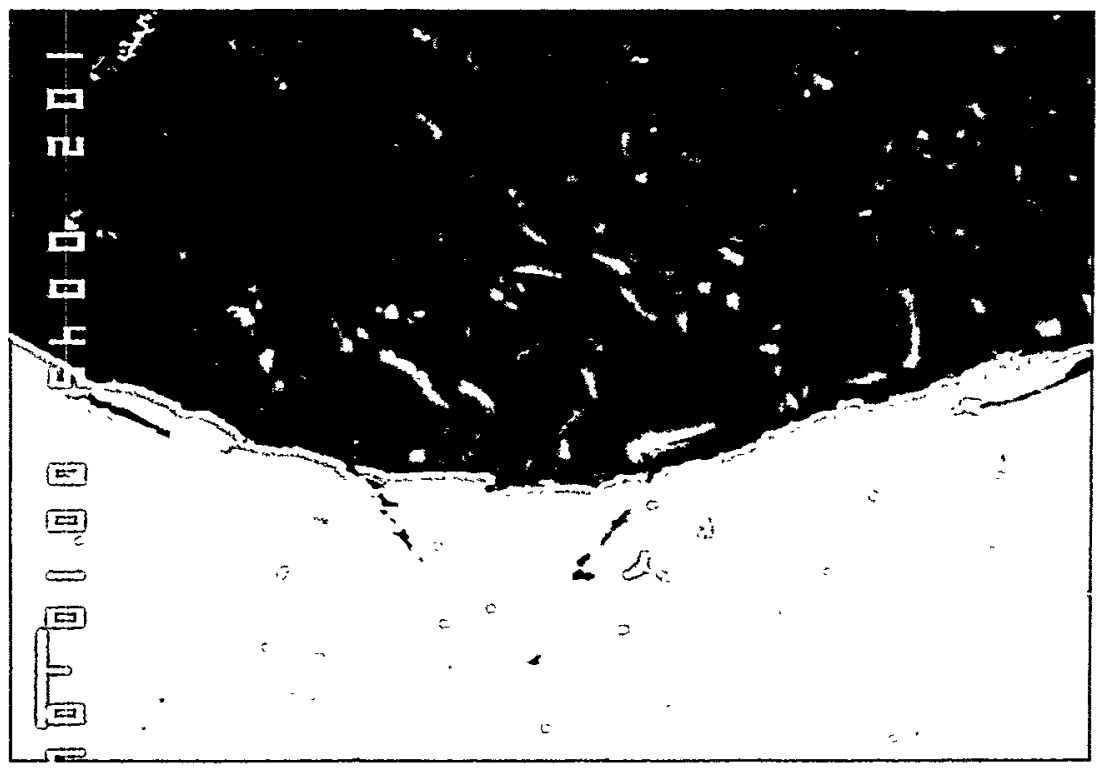

Figure 29 An SEM micrograph of part of the notch root of a sensitized Type 316L stainless steel specimen tested in the steam/air phase above boiling J-13 water for six months (x1000).

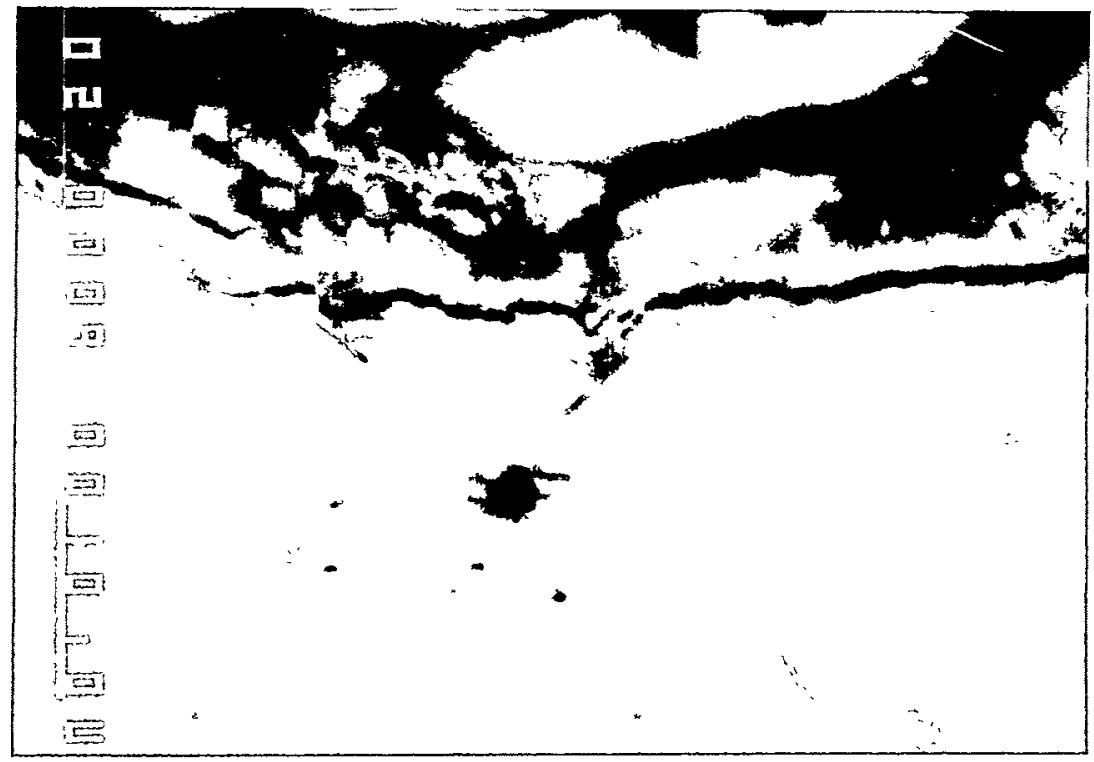

Figure 30 A SEM micrograph of part of the notch root of an as-received (solution annealed) Type $316 \mathrm{~L}$ stainless steeI specimen tested in boiling $10 \mathrm{xJ}-13$ solution for six months ( $x 2000)$. 


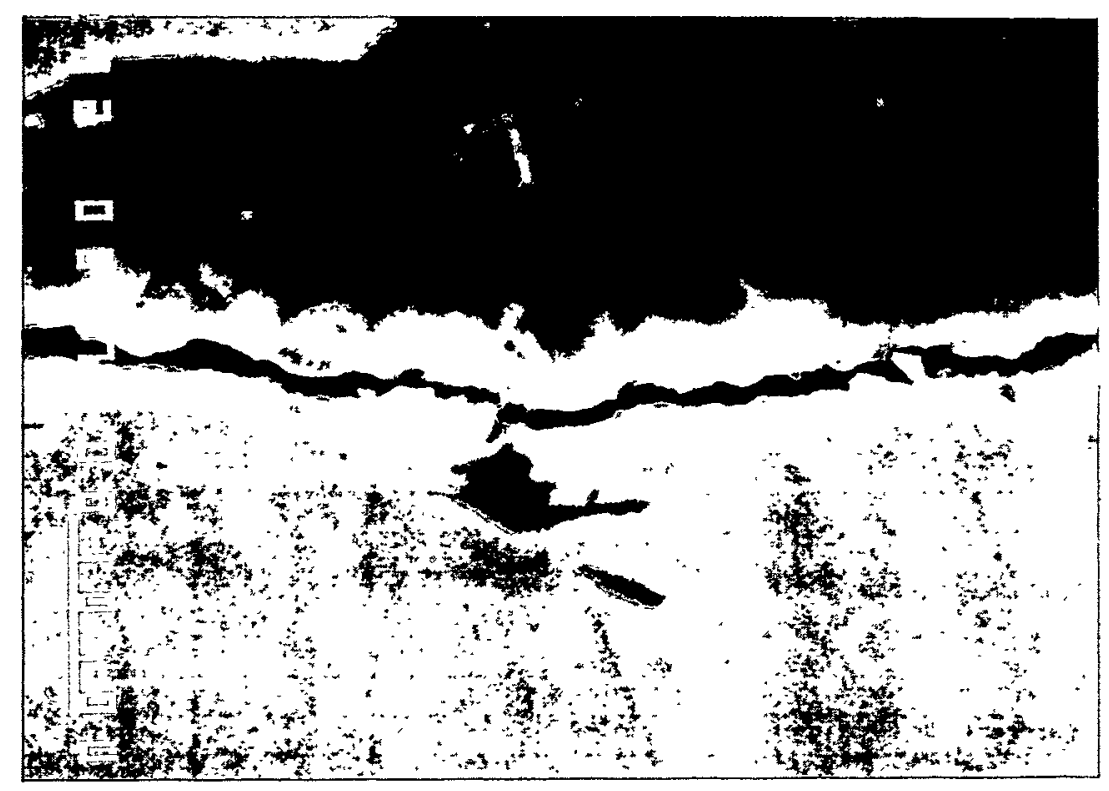

Figure 31 A SEM micrograph of part of the notch root of an as-received (solution annealed) Type $316 \mathrm{~L}$ stainless steel specimen tested in boiling $10 \mathrm{xJ}-13$ solution for six months ( $x 2000)$.

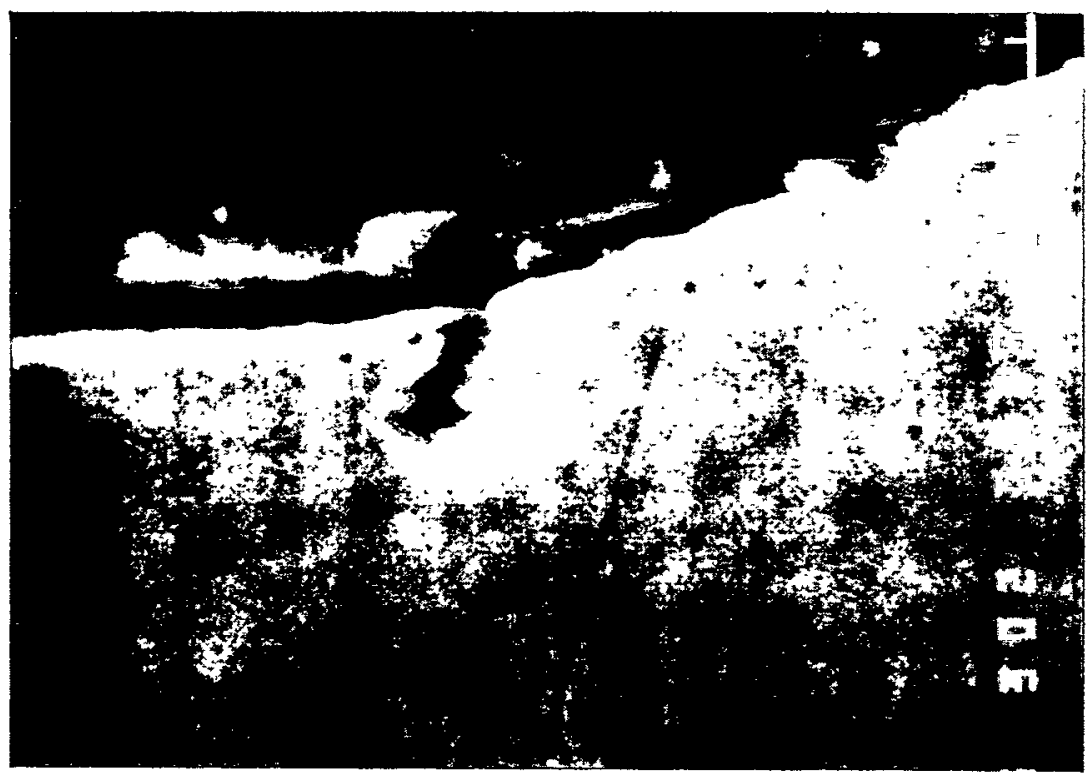

Figure 32 A SEM micrograph of part of the notch root of a sensitized Type 316L stainless steel tested in boiling $10 x J-13$ solution for six months ( $x 3000)$. 


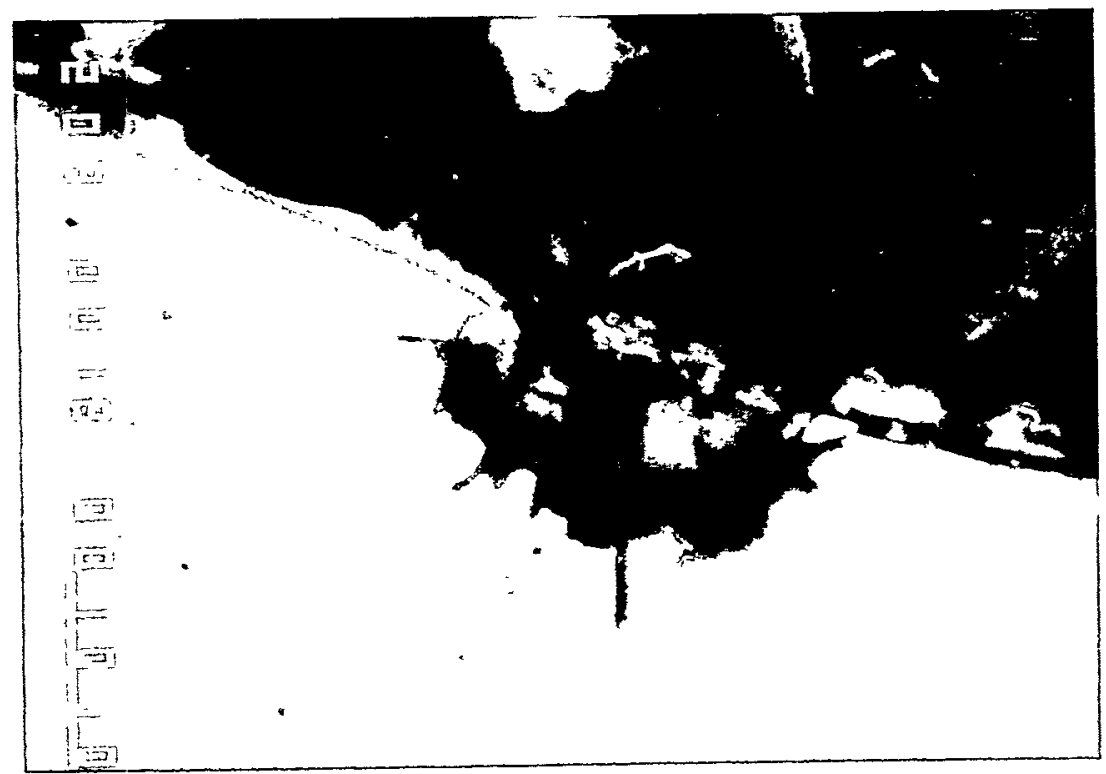

Figure 33 An SEM micrograph of part of the outer diameter of an as-received (solution annealed) Type 316L stainless steel tested in boiling $\mathrm{J}-13$ water for twelve months (x2000).

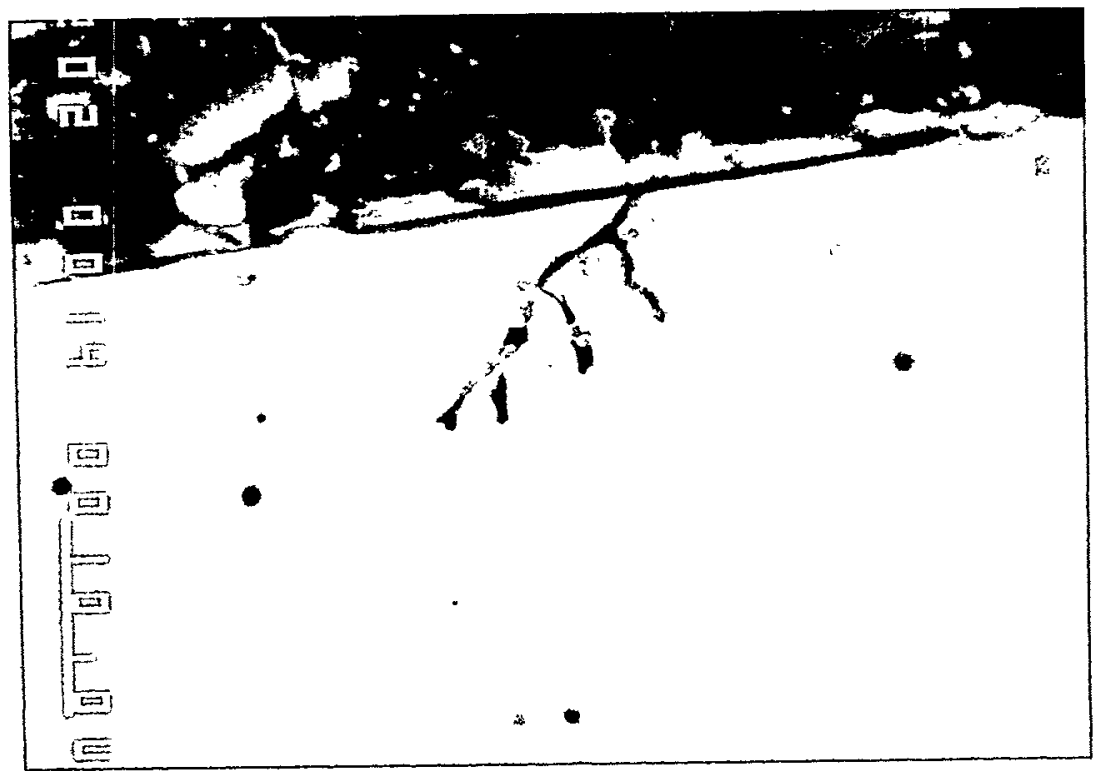

Figure 34 An SEM micrograph of part of the outer diameter of an as-received (solution annealed) Type 316L stainless steel tested in boiling $\mathrm{J}-13$ water for twelve months ( $\mathrm{x} 2000)$. 
Table 16 Stress corrosion cracking tests for Type 316L stainless steel.

\begin{tabular}{|c|c|c|c|c|c|}
\hline \multirow{2}{*}{$\begin{array}{l}\text { Test Time } \\
\text { (Months) }\end{array}$} & \multirow{2}{*}{$\begin{array}{c}\text { Specimen } \\
\text { Conditions }\end{array}$} & \multicolumn{2}{|c|}{ Steam Test } & \multicolumn{2}{|c|}{ Water Test } \\
\hline & & $\overline{J-13 \text { Water }^{2}}$ & $10 \times \mathrm{J}-13$ Water $^{2}$ & $\mathrm{~J}-13$ Water $^{\mathrm{a}}$ & $10 \times \mathrm{J}-13$ Water \\
\hline \multirow[t]{2}{*}{3} & As Received & N.E. b & N.E. & $\begin{array}{l}2 / 2^{\mathrm{c}} \\
21 \mu^{\mathrm{d}}\end{array}$ & N.E. \\
\hline & Sensitized & N.E. & $\begin{array}{l}2 / 2 \\
23 \mu\end{array}$ & N.E. & N.E. \\
\hline \multirow{2}{*}{6} & As Received & $\begin{array}{l}1 / 1 \\
13 \mu \text { (notch } \\
\text { root) }\end{array}$ & $\begin{array}{l}2 / 2 \\
20 \mu\end{array}$ & $\begin{array}{l}2 / 2 \\
24 \mu \text { (1 at } \\
\text { notch root) }\end{array}$ & $\begin{array}{l}2 / 2 \\
12 \text { (both } \\
\text { notches) }\end{array}$ \\
\hline & Sensitized & $\begin{array}{l}1 / 2 \\
25 \mu\end{array}$ & $\begin{array}{l}1 / 3 \\
5 \mu\end{array}$ & $\begin{array}{l}2 / 2 \\
20 \mu \text { (1 at } \\
\text { notch root) }\end{array}$ & $\begin{array}{l}2 / 2 \\
14 \mu\end{array}$ \\
\hline \multirow{2}{*}{12} & As Received & $\begin{array}{l}1 / 1 \\
26 \mu\end{array}$ & $\begin{array}{l}1 / 2 \\
20_{\mu}\end{array}$ & $\begin{array}{l}2 / 2 \\
18 \mu\end{array}$ & $0 / 1$ \\
\hline & Sensitized & $\begin{array}{l}\text { (difficult to } \\
\text { identify due } \\
\text { to heavy } \\
\text { etching) }\end{array}$ & N.E. & $\begin{array}{l}\quad \text { o/ } 1 \\
\text { (possible } \\
\text { transgranular } \\
\text { crack } \\
\text { initiation) }\end{array}$ & $0 / 1$ \\
\hline
\end{tabular}

a) The composition of test solution changes substantially with time. See Table 19 for detailed composition.

b) Not examined (N.E.)

c) Specimens with microcracks/number of specimens examined. Some starting material had minute cracks, which could influence crack initiation data. See text for discussion.

d) Maximum crack length in $\mu$. 


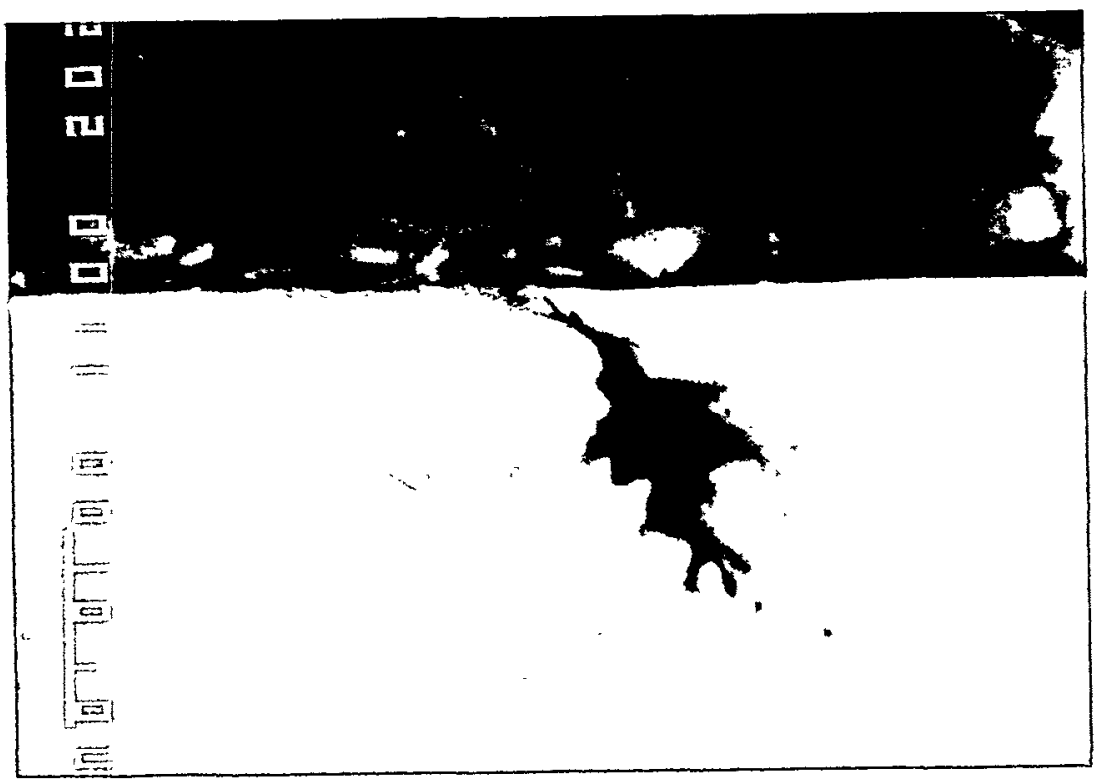

Figure 35 An SEM micrograph of part of the outer diameter of an as-received (solution annealed) Type 316L stainless steel tested in steam/air phase above boiling $10 \mathrm{xJ}-13$ solution for twelve months ( $\mathrm{x} 2000)$.

\subsection{Type 321 Stainless Stee1}

Two as-received, untested specimens examined under the SEM showed no cracks or pits in the V-notch or the areas around the V-notch. Table 17 gives a summary of the stress corrosion cracking behavior of Type 321 stainless steel.

of the two specimens examined from the three-month tests, neither had any cracks. Cracks were, however, detected in specimens tested for 6 months in the water phase as well as in the steam/air phase for ten-times-concentrated $\mathrm{J}-13$ water. Figure 36 shows crack propagation in an as-received specimen tested in the steam/air phase above boiling ten-times-concentrated J-13 water. As the crack propagates, some areas inside the crack become corroded and small grains may have become dislodged by metallographic polishing.

Figure 37 shows an SEM micrograph for a Type 321 stainless steel specimen tested in ten-times-concentrated J-13 groundwater for six months. It seems that one whole region is corroded. Along the scanning line through the corroded area, $X$-ray line profiles for oxygen, iron, and chromium were performed and are also shown in Figure 37. The scanning line intersects two 
Table 17 Stress corrosion cracking tests for Type 321 stainless steel.

\begin{tabular}{|c|c|c|c|c|c|}
\hline \multirow{2}{*}{$\begin{array}{c}\text { Test Time } \\
\text { (Months) }\end{array}$} & \multirow{2}{*}{$\begin{array}{l}\text { Specimen } \\
\text { Conditions }\end{array}$} & \multicolumn{2}{|c|}{ Steam Test } & \multicolumn{2}{|c|}{ Water Test } \\
\hline & & J-13 Water ${ }^{\mathrm{a}}$ & $10 \times \mathrm{J}-13$ Water ${ }^{\mathrm{a}}$ & J-13 Water ${ }^{a}$ & $10 \times J-13^{a}$ \\
\hline \multirow[t]{2}{*}{3} & As Received & N.E.b & N.E. & $\begin{array}{l}\text { N.E. } \\
21 \mu\end{array}$ & N.E. \\
\hline & Sensitized & N.E. & N.E. & N.E. & $0 / 2$ \\
\hline \multirow{2}{*}{6} & As Received & N.E. & $\begin{array}{l}2 / 2 \mathrm{c} \\
25 \mu^{d}\end{array}$ & N.E. & $\begin{array}{l}2 / 2 \\
55 \mu\end{array}$ \\
\hline & Sensitized & N.E. & $0 / 2$ & $N \cdot E$. & $\begin{array}{l}1 / 2 \\
25 \mu\end{array}$ \\
\hline \multirow{2}{*}{12} & As Received & $0 / 1$ & N.E. & N.E. & $\begin{array}{l}0 / 2 \\
\text { (Pitting on o.d. } \\
\text { of } 1 \text { sample) }\end{array}$ \\
\hline & Sensitized & $0 / 1$ & $0 / 1$ & $0 / 1$ & $\begin{array}{l}1 / 2 \\
65 \mu\end{array}$ \\
\hline
\end{tabular}

a) The composition of test solution changes substantially with time.

See Table 19 for detalled composition.

b) Not examined (N.E.)

c) Specimens with microcracks/number of specimens examined.

d) Maximum crack length in $\mu$. 
regions (probably grain boundaries) which are rich in chromium and iron. Between these regions is an area rich in iron but containing some oxygen also. The corroded area extends to a depth of $50 \mu$ from the outer edge of the specimen. It is not clear, whether stress corrosion or simple intergranular attack is responsible.

Figure 38 shows an SEM micrograph of a sensitized specimen tested in boiling ten-times-concentrated $\mathrm{J}-13$ water for one year. The crack initiating from the outer diameter of the specimen extends up to a depth of $65 \mu$, which is the largest crack observed in this investigation. However, several other specimens tested under different conditions for one year did not show any crack initiation.

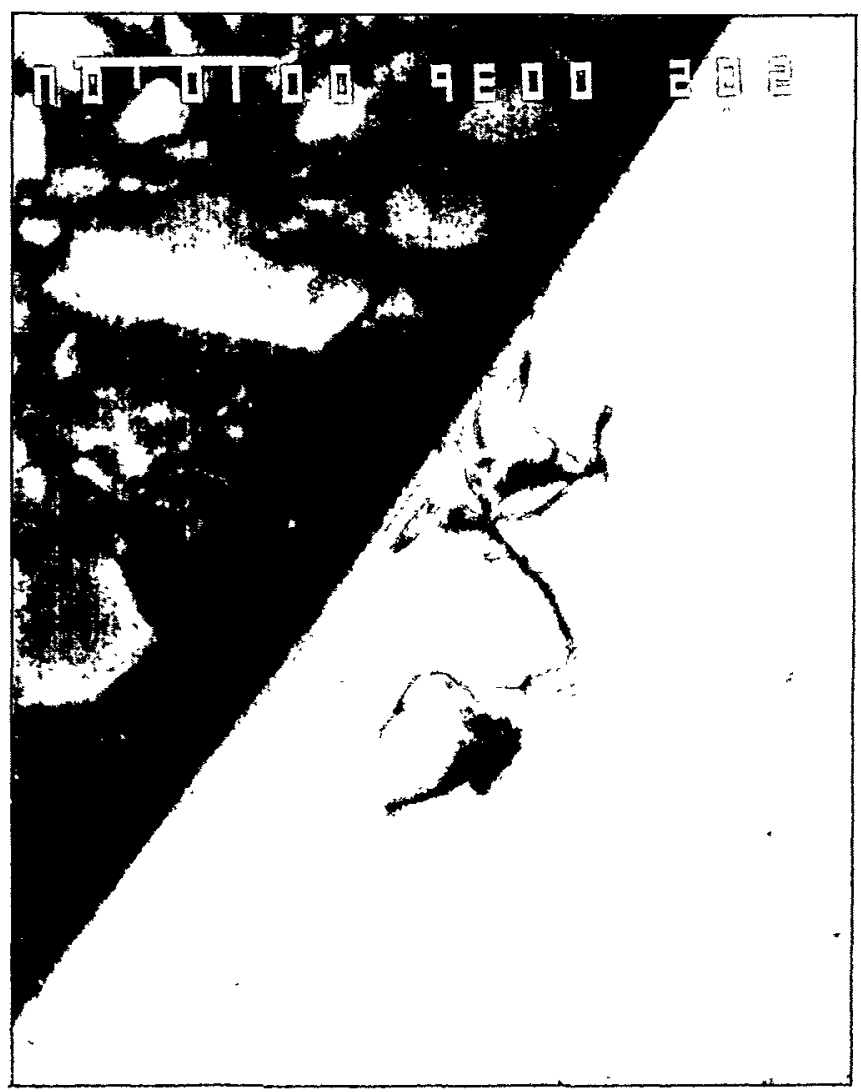

Figure 36 An SEM micrograph of part of the outer diameter of an as-received (solution annealed) Type 321 stainless steel tested in steam/air phase above boiling $10 \mathrm{xJ}-13$ water for six months (x2000). 


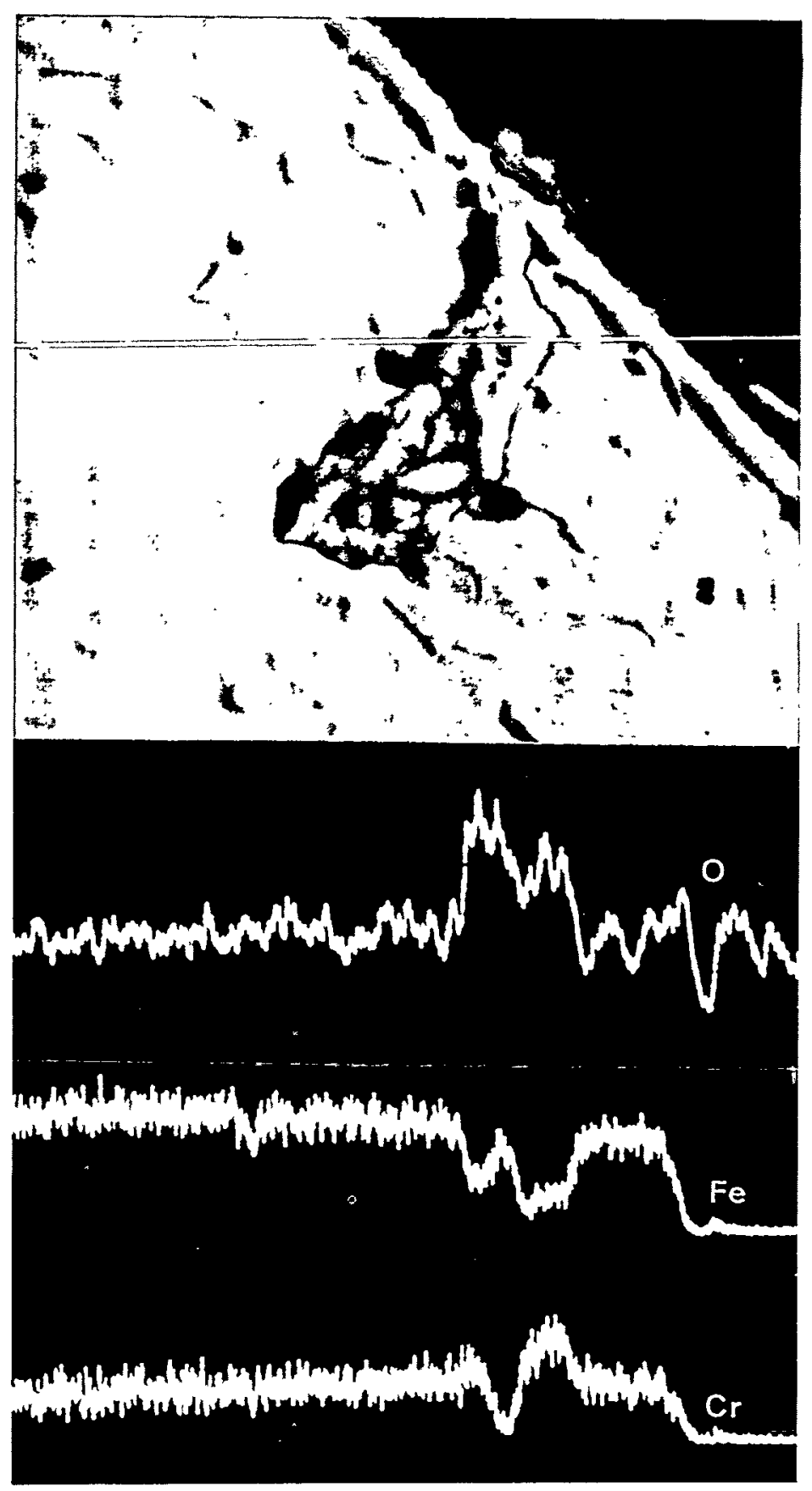

Figure 37 An SEM micrograph of part of the outer diameter of an as-received (solution annealed) Type 321 stainless steel specimen tested in boiling $10 \mathrm{xJ}-13$ solution for six months $(\mathrm{xl00})$. X-ray line profiles for $\mathrm{Fe}, \mathrm{Cr}$, and 0 are shown. 


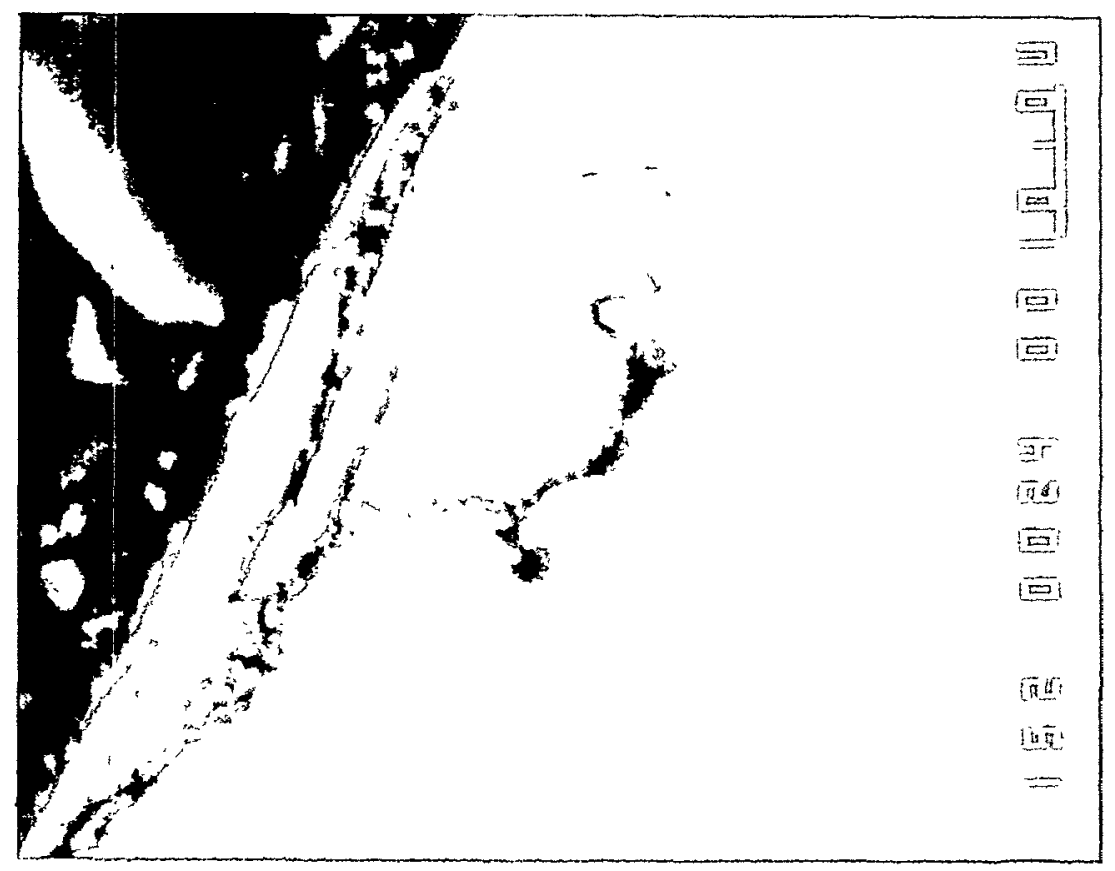

Figure 38 An SEM micrograph of part of the outer diameter of a sensitized Type 321 stainless steel specimen tested in boiling $10 \mathrm{xJ}-13$ solution for one year (x1500).

\subsection{Incoloy 825}

An SEM examination of two as-received, untested specimens showed no cracks or pits on the specimen surfaces or within the V-notch. Table 18 gives a summary of the stress corrosion cracking behavior of Incoloy 825 .

None of the 3-month test specimens of Incoloy 825 was examined under the SEM due to limited time. Of the twelve 6-month and 12-month test specimens examined under optical and scanning electron microscopes, only one test specimen from a 6-month test had cracks. The cracks appeared at the notch root and are shown in Figure 39. To identify the material inside the crack, one of the cracks was examined under high magnification and X-ray line profiles for oxygen, iron, chromium and nickel were performed and are shown in Figure 40. There is depletion of $\mathrm{Cr}, \mathrm{Fe}$, and Ni inside the crack compared to the base alloy. There is also depletion of oxygen inside the crack; however, there is oxygen at the crack surfaces. To further examine the material inside the 
Table 18 Stress corrosion cracking tests for Incoloy 825.

\begin{tabular}{|c|c|c|c|c|c|}
\hline \multirow{2}{*}{$\begin{array}{r}\text { Test Time } \\
\text { (Months) }\end{array}$} & \multirow{2}{*}{$\begin{array}{l}\text { Specimen } \\
\text { Conditions }\end{array}$} & \multicolumn{2}{|c|}{ Steam Test } & \multicolumn{2}{|c|}{ Water Test } \\
\hline & & J-13 Watera & $10 \times \mathrm{J}-13$ Water $^{a}$ & $\mathrm{~J}-13$ Water ${ }^{\mathrm{a}}$ & $10 \times \mathrm{J}-13$ Water $^{\mathrm{a}}$ \\
\hline \multirow{2}{*}{3} & As Received & $N \cdot E \cdot b$ & $\mathrm{~N} \cdot \mathrm{E}$. & N.E. & N.E. \\
\hline & Sensitized & N.E. & N.E. & N.E. & N.E. \\
\hline \multirow{2}{*}{6} & As Received & $\mathrm{N} \cdot \mathrm{E}$. & $\begin{array}{l}1 / 1^{c} \\
40 \mu^{d}\end{array}$ & N.E. & $0 / 2$ \\
\hline & Sensitized & N.E. & $0 / 2$ & N.E. & $0 / 2$ \\
\hline \multirow{3}{*}{12} & As Received & $N \cdot E$. & $0 / 1$ & $\mathrm{~N} \cdot \mathrm{E}$. & $0 / 1$ \\
\hline & & & & & \\
\hline & Sensitized & $\mathrm{N} . \mathrm{E}$. & $0 / 1$ & $0 / 1$ & $0 / 1$ \\
\hline
\end{tabular}

a) The composition of test solution changes substantially with time.

See Table 19 for detailed composition.

b) Not examined (N.E.)

c) Specimens with microcracks/number of specimens examined.

d) Maximum crack length in $\mu$. 


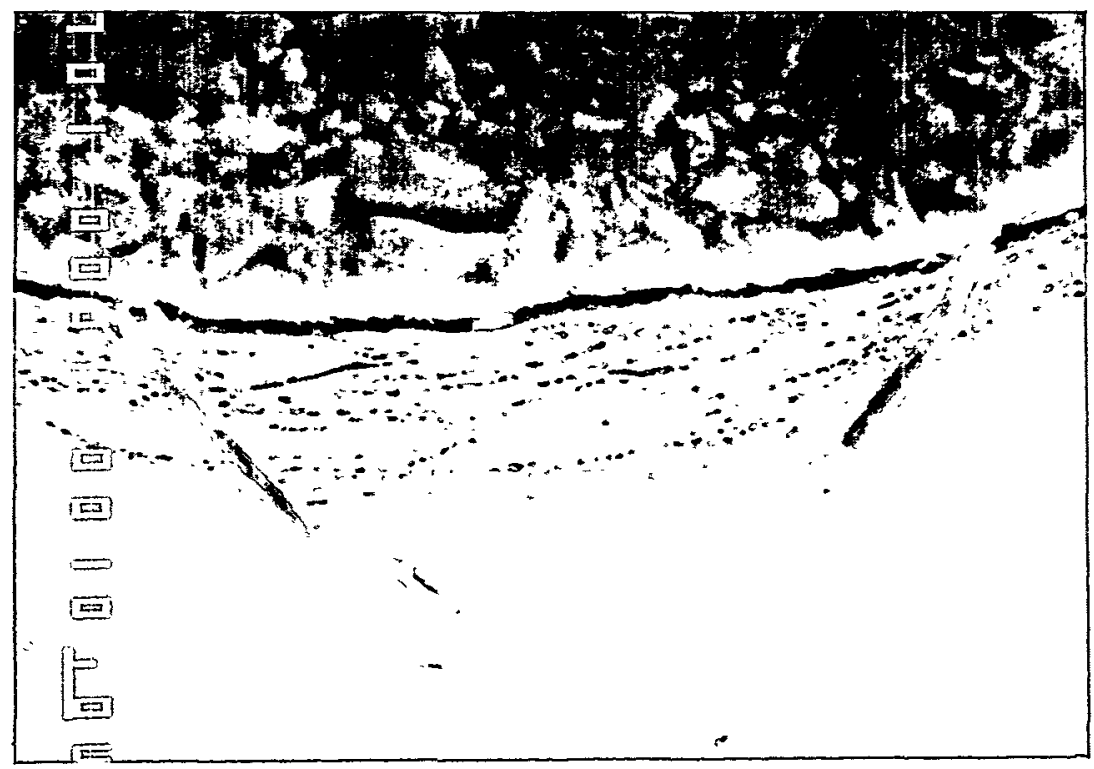

Figure 39 An SEM micrograph of part of the notch root of an as-recelved (solution annealed) Incoloy 825 specimen tested in steam/air phase above boiling $10 \mathrm{xJ}-13$ water for six months $(\mathrm{x} 700)$.

crack, an EDAX analysis was made at the crack tip and is shown in Figure 41 . Figures $4 \mathrm{lb}$ and $4 \mathrm{lc}$ show EDAX analyses for the specimen matrix and the mounting material. Comparison of the three sets of EDAX peaks shows that the material inside the crack is a mixture of the specimen mounting material and chromium, iron, nickel, and oxide(s).

\subsection{Salt Deposition During Test}

It was found that during the tests salts deposit on the specimens. SmaII pieces of tuff were also found attached to the surfaces of some specimens exposed for six and twelve months in the steam/air phase, presumably due to the deposition of salts at and around the contact areas. Deposition of salts in the 3-month tests was not sufficient to cause attachment.

All C-ring specimens tested in solution have a coating of salt and corrosion scale, whereas stainless steel specimens in the steam phase showed patches of unreacted metal surrounded by a brown, rust-colored scale. In contrast to the stainless steels, Incoloy specimens in steam do not show any scale.

In some areas on the surfaces of 3-month test specimens exposed to the 1iquid phase, black spots which appeared to be shallow pits under an optical 


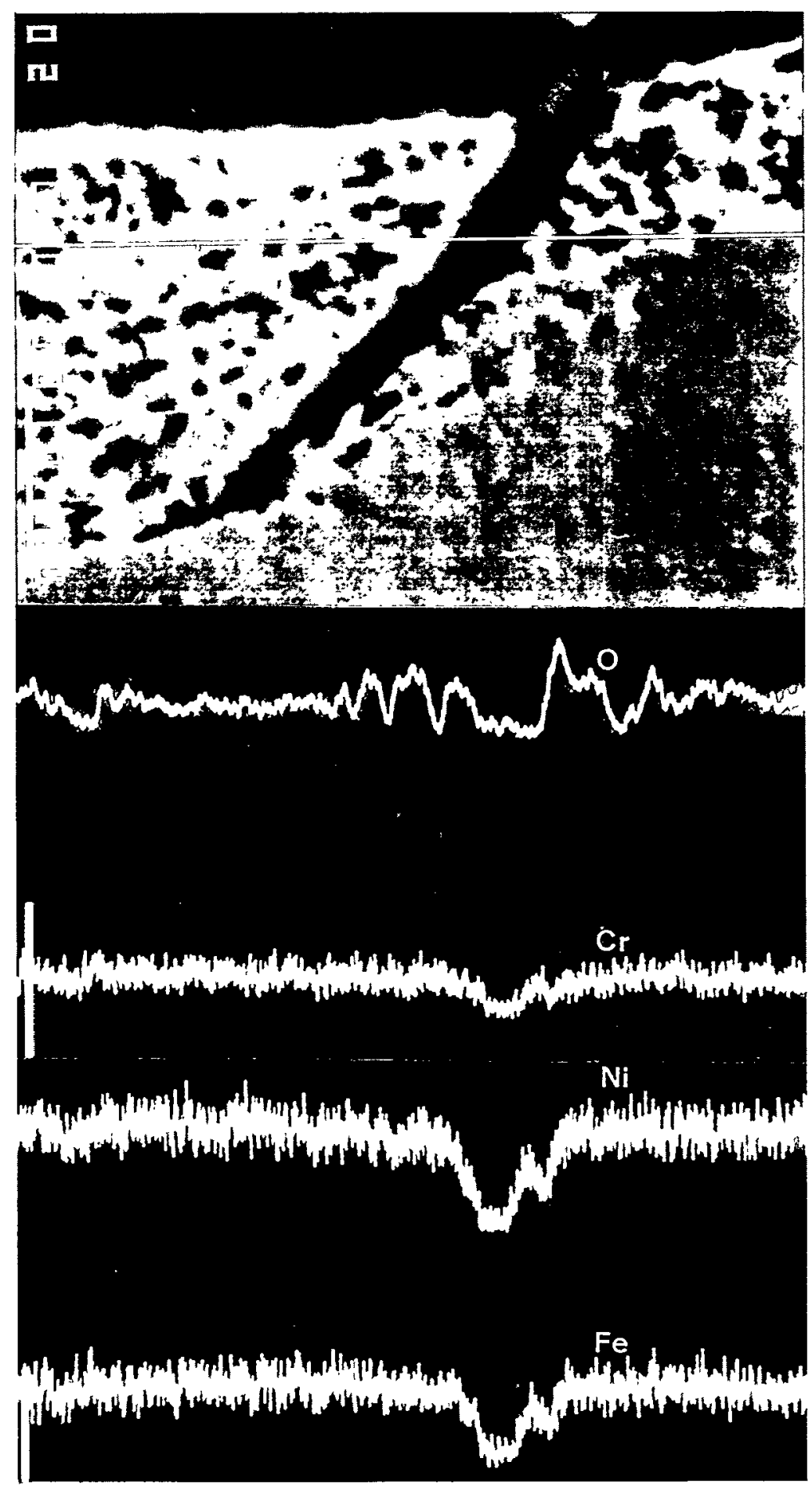

Figure 40 An SEM micrograph of part of the notch root of an as-received (solution annealed) Incoloy 825 specimen tested in steam/air phase above boiling $10 x J-13$ water for six months ( $x 2000)$. $\mathrm{X}$-ray line profiles for $\mathrm{O}, \mathrm{Cr}, \mathrm{Ni}$ and $\mathrm{Fe}$ are shown. 


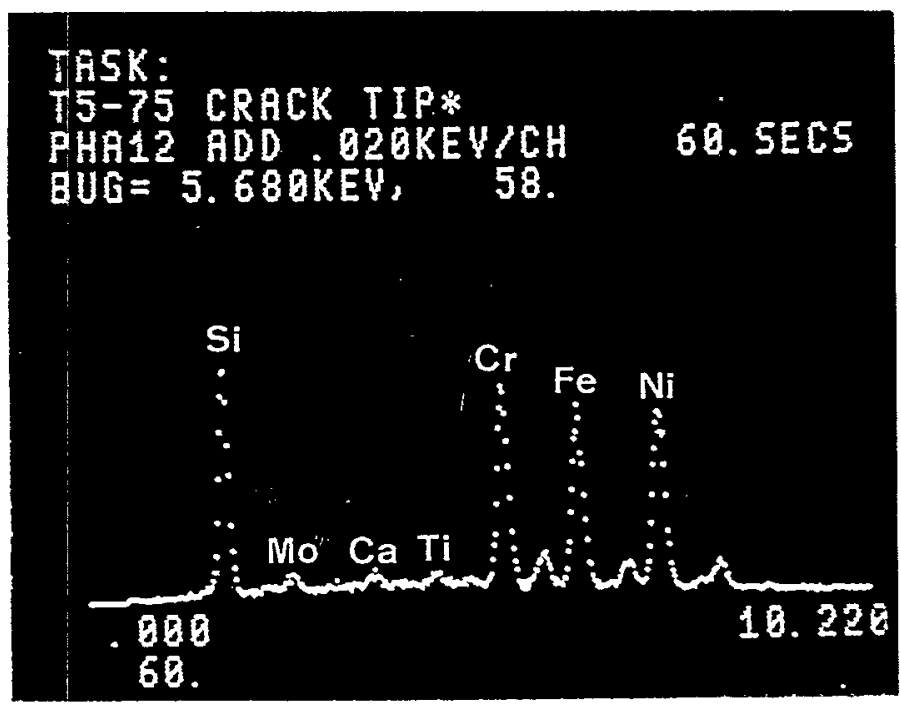

Figure 4la An EDAX analysis of the crack tip shown in Figure 40.

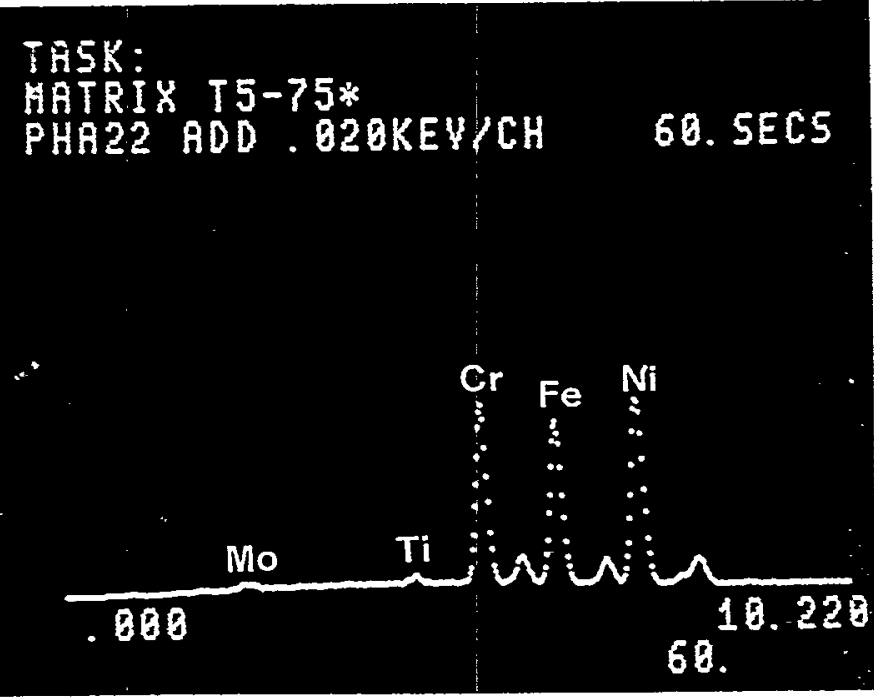

Figure 41b An EDAX analysis of the specimen matrix material shown in Figure 40 .
TAER:

HOUHTING MATERIAL*

PHA12 ADD. O2OKEV/CH 60. SECS

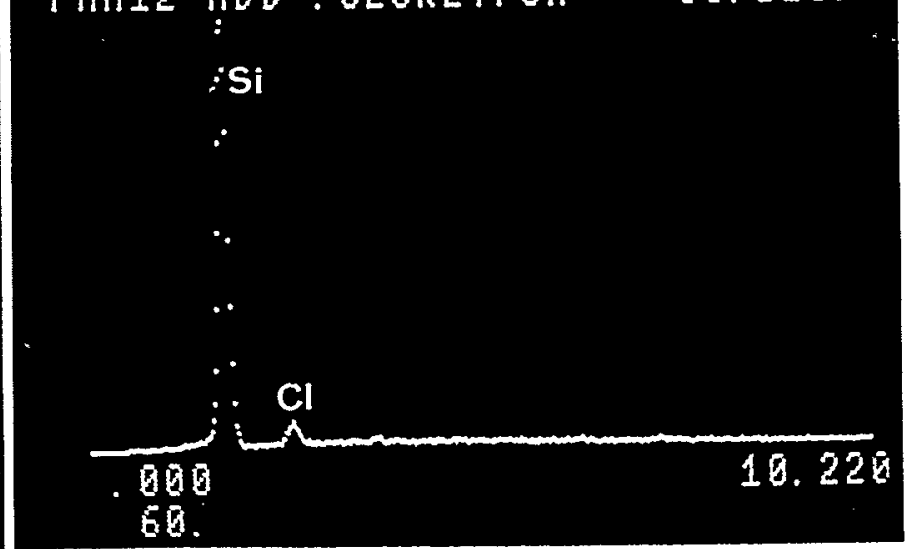

Figure 4lc An EDAX analysis of the mounting material shown in Figure 40 . 
microscope were observed. However, under the SEM/microprobe these were determined to be a thin growth of some compound predominantly containing calcium and sulfur, with no indication of pits in the metal (see Figure 42).

On the surface of specimens tested in ten-times-concentrated $\mathrm{J}-13$ water, small deposits were occasionally observed. They could not be removed by ultrasonic cleaning for times up to one hour in water. It was suspected that pits might be present under such deposits, so they were scraped away with a sharp needle and the area below was examined using optical and scanning electron microscopy. Figure 43 shows an optical micrograph of one such area. In this case the deposit was present at the center of the black circular area. The boundary, and a small part of the deposit, are still seen. Microprobe analysis of the deposits suggests that they consist predominantly of $S i$ and small amounts of $\mathrm{Al}, \mathrm{Ca}, \mathrm{K}$ and $\mathrm{Cl}$.

It was also found that a few days after starting each test, small amounts of a white solid appeared on the test vessel interior and on some of the tuff pieces near the top of the vessel in the steam/air phase. A typical micrograph of the white compound is shown in Figure 44. An electron diffraction pattern of this compound shows diffuse rings typical of an amorphous solid, and silicon is the only element identified by micro-probe analyses. Therefore, it is inferred that the white compound is amorphous silica which is transported via the vapor phase to cooler areas of the test vessel. Considering the presence of a large amount of $\mathrm{SiO}_{2}$ in solution, as well as in tuff, the precipitation of amorphous silica is reasonable. Silica may also have entered the solution from the Pyrex test vessel which showed leached areas at the end of each test. 


\section{WATER CHEMISTRY MEASUREMENTS}

To understand the chemistry of the test solutions, and to determine the possible range of compositions of repository groundwaters, a sample of each test solution was removed via the central tube at the conclusion of the 3-, 6and 12-month tests. Part of each sample was cooled to room temperature and then analyzed; the data are shown in Table 19. In addition, a parallel test was conducted in a vessel similar to the ones used in the C-ring tests. The vessel was filled with crushed tuff (0.165 to 0.0187 inch size) and distilled water, and then maintained under boiling water conditions. The chemical analysis of the solution obtained at the end of a one-month period is given in the third column of Table 19 (Sample \#2). At this time, the solution was drained and $1150 \mathrm{~mL}$ of fresh distilled water was added to the vessel. After the system had been kept under boiling water conditions for another month, an aliquot of the test solution was collected and analyzed. The chemical composition is given in the fourth column of Table 19 (Sample $\#_{4}$ ). Once again, the existing solution was drained and a fresh $1000 \mathrm{~mL}$ of distilled water was added to the vessel. The system was then maintained under boiling water conditions for an additional seven weeks before collecting $50 \mathrm{~mL}$ of the test solution for chemical analysis. The remaining system was maintained under boiling water conditions for four-months and one week, giving a total test period of six months. A final solution sample was taken for analysis. The analyses of the two latter samples are shown in Table 19 (Samples 16 and 17, respectively).

A comparison of the chemical analyses of the first three solutions successively reacted with crushed tuff shows that the concentration of all cations ( $\mathrm{Na}^{+}, \mathrm{K}^{+}$and $\mathrm{Ca}^{2+}$ ) and $\mathrm{Cl}^{-}, \mathrm{F}^{-}$and $\mathrm{NO}_{3}^{-}$ions decreased each time the solution was replaced by distilled water. This suggests that there is only a limited source of these ions in the crushed tuff. The concentration of $\mathrm{SO}_{4}{ }^{2-}$ ions does not show a monotonic change, but reaches a maximum value after which it decreases.

From the analyses on water samples 16 and 17 it seems that the concentrations of most species in solution are reaching stable values at the 6-month period.

As explained earlier, at the conclusion of the 3-, 6- and 12-month tests, samples of the test solutions were removed from the test vessels. To determine whether any precipitation takes place during cooling to room temperature, parts of the samples were mixed with equal amounts of boiling distilled water and then cooled. The dilution was expected to prevent precipitation. Both undiluted and diluted samples were filtered through Whatman 42 filter paper. A comparison of results for undiluted and diluted solutions suggests that dilution by a factor of two reduces the concentrations approximately by a factor of two for all species. Therefore, no significant precipitation appears to occur. However, from the following argument it appears that colloids are formed during cooling, which can freely pass through the filter paper. 


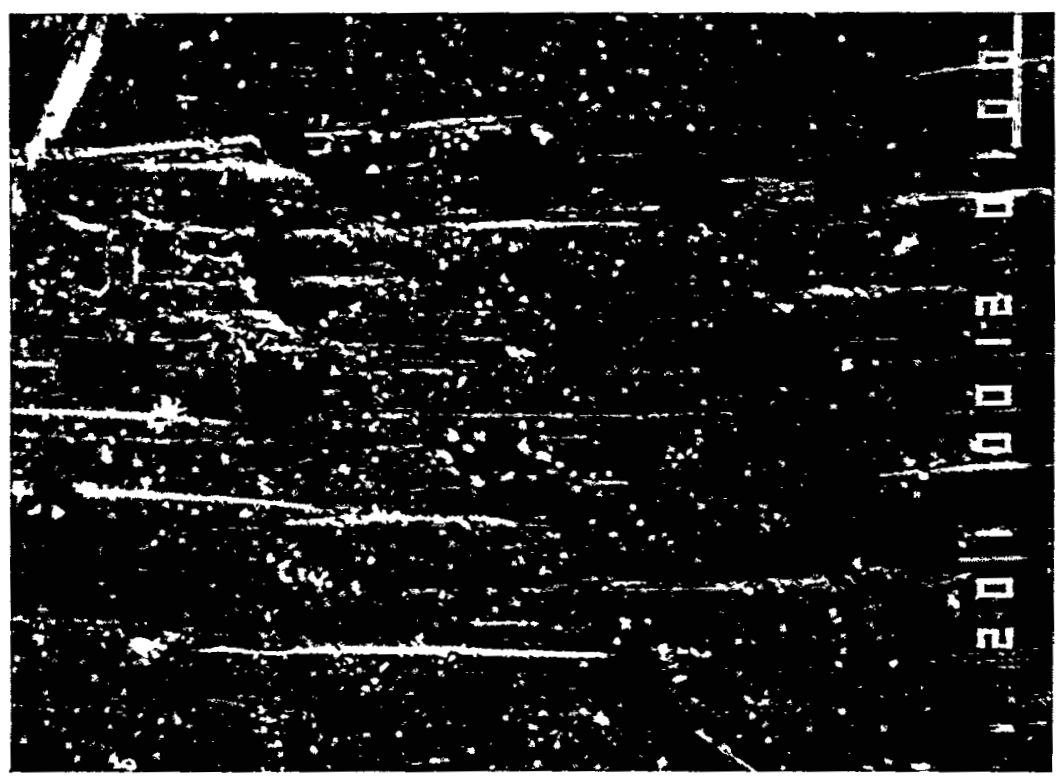

Figure 42 An SEM micrograph of the surface of a sensitized Type 304L stainless steel specimen showing black spots. The specimen was exposed to J-13 groundwater for three months. (x1000)

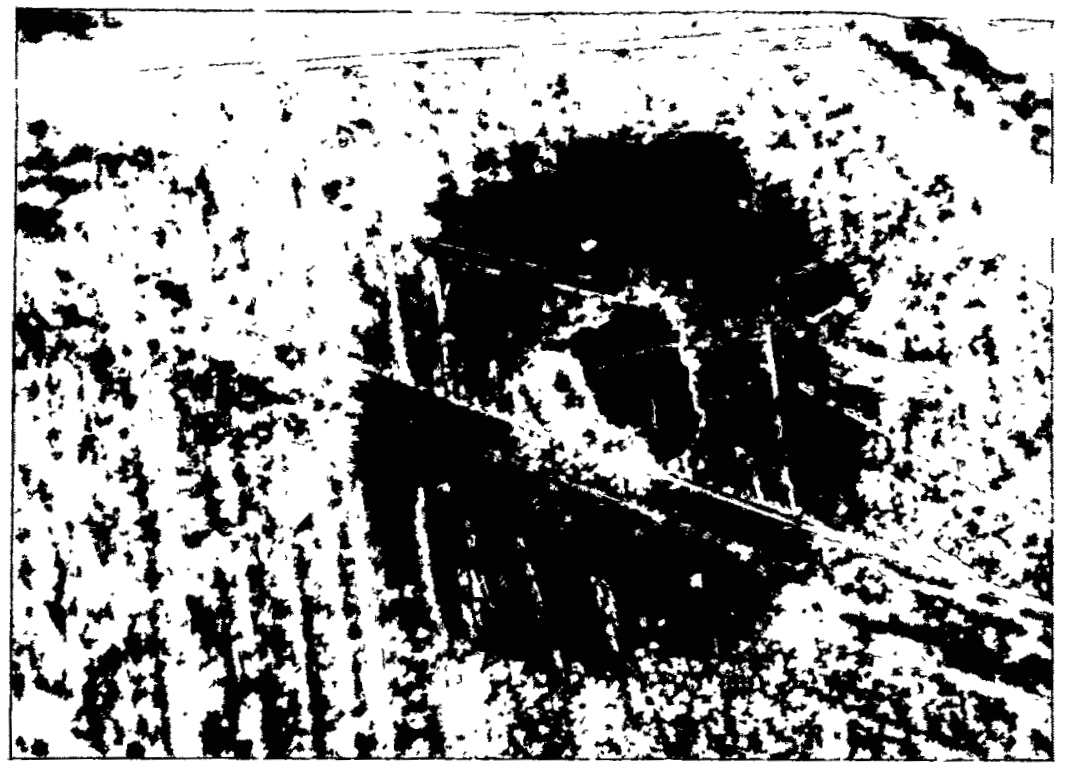

Figure 43 Optical micrograph of the surface of a sensitized Type 316L stainless steel specimen tested in $10 \mathrm{xJ}-13$ water for three months. The dark circle shows the area from where a salt layer has been removed mechanically. The boundary inside the circle corresponds to the area where a deposit predominantly containing $\mathrm{Si}, \mathrm{Ca}$, $\mathrm{Al}$ was present ( $\mathrm{x} 500)$. 


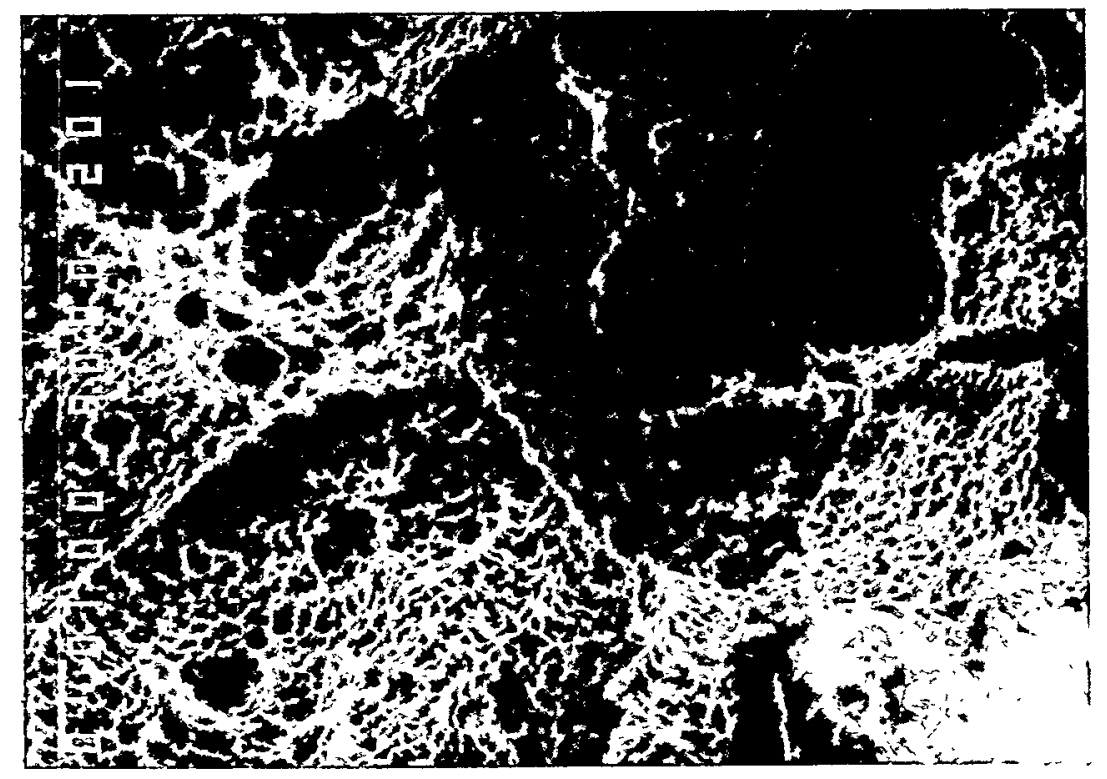

Figure 44 An SEM micrograph of the white compound found on the inside of the lid of the test vessel ( $x 1000)$.

Consider, for example, the concentration of $\mathrm{SiO}_{2}$ in different test solutions which is $\approx 459 \mu \mathrm{g} / \mathrm{mL}$ irrespective of the composition of the starting solution (see Table 19). This implies that at the test temperature the solutions are saturated in $\mathrm{SiO}_{2}$ and, therefore, supersaturated with $\mathrm{SiO}_{2}$ when the temperature is lowered. But the comparison of the chemical analyses of the normalconcentration and diluted solutions does not indicate that precipitation occurs, thus suggesting the formation of colloids on cooling. We have not attempted to characterize the nature of colloids, but a similar argument applies to other species for which solubility decreases with temperature. In earlier work (UCRL-53574, 1984) on the reaction of the Topopah Spring tuff with $\mathrm{J}-13$ water at $120^{\circ} \mathrm{C}$, the silicon solubility was determined to be about 75 $\mathrm{ppm}$ (or about $160 \mathrm{ppm}$ of $\mathrm{SiO}_{2}$ ). This further indicates that colloids containing $\mathrm{SiO}_{2}$ formed in the test solution while cooling to room temperature.

To determine the concentration of any particles suspended in solution, one of the samples in the 3-month test (Sample 11) was analyzed without filtering and its analysis was compared to the filtered sample (Sample 10). A comparison of the two given in Table 19 indicates that there is no significant amount of suspended solid material which could be filtered through a Whatman 42 paper. To confirm whether any precipitation occurs in the presence of tuff rocks at room temperature, $150 \mathrm{~mL}$ of ten-times-concentrated $\mathrm{J}-13$ solution was 
Table 19 Composition of $\mathrm{J}-13$ and $10 \mathrm{xJ}-13$ solution during stress corrosion experiments.

\begin{tabular}{|c|c|c|c|c|c|c|c|c|c|c|c|c|c|c|c|c|c|c|c|}
\hline & & & & & & & Thr & onth ? & & & & & inth $T$ & & & Twe & lonth & Test & \\
\hline & & & $\begin{array}{l}\text { Tuf f- } \\
\text { ter } \mathrm{Re}\end{array}$ & stille & & $\begin{array}{l}\text { Synth } \\
\mathrm{J}-13\end{array}$ & tate & & & & $\begin{array}{l}\text { Synth } \\
\text { J-13 }\end{array}$ & $\begin{array}{l}\text { etic } \\
\text { Hater }\end{array}$ & & & $\begin{array}{l}\text { Syn } \\
\mathrm{J}-1\end{array}$ & $\begin{array}{l}\text { het } 1 c \\
\text { Wate }\end{array}$ & & & \\
\hline & (a) & $\begin{array}{l}\text { (b) } \\
12(\mathrm{c})\end{array}$ & $\begin{array}{l}\text { (d) } \\
44\end{array}$ & $\begin{array}{l}\text { (e) } \\
\$ 16\end{array}$ & $\begin{array}{l}\text { (f) } \\
\| 17\end{array}$ & $\begin{array}{l}(8) \\
47\end{array}$ & $\begin{array}{l}\text { (b) } \\
16\end{array}$ & (g) & $\begin{array}{l}\text { (h) } \\
: 99\end{array}$ & $\begin{array}{l}(1) \\
\| 11\end{array}$ & $\begin{array}{l}(\mathrm{g}) \\
\| 15\end{array}$ & (b) & & $\begin{array}{l}\text { (h) } \\
\| 12\end{array}$ & & $\begin{array}{l}\text { (h) } \\
\| 18\end{array}$ & & (h) & $\frac{(j)}{\| 22}$ \\
\hline $\mathrm{Na}^{+}$ & 45 & 308 & 190 & 42 & 167 & - & - & 867 & 420 & 960 & 464 & 217 & 738 & 338 & 510 & 280 & 908 & 472 & 897 \\
\hline $\mathrm{K}^{+}$ & 4.9 & 50.5 & 21 & 2.0 & 13.2 & 238 & 113 & 244 & 115 & 255 & 244 & 113 & 214 & 97.1 & 106 & 64.0 & 139 & 80.5 & 83.0 \\
\hline $\mathrm{Cs}^{2+}$ & 14 & 930 & 298 & 122 & 132 & 308 & 151 & 301 & 161 & 332 & 161 & 68.5 & 164 & 67.5 & 104 & 48.4 & 129 & 54 & 134 \\
\hline$s r^{2+}$ & - & - & - & - & 1.2 & 3.4 & 2.0 & 4.4 & 2.2 & 4.2 & 0.4 & 0.2 & 0.5 & $<0.1$ & 1.0 & 0.5 & 1.2 & 0.5 & 1.7 \\
\hline$F^{-}$ & 2.2 & 8.5 & $<4$ & 2 & 2 & 12.1 & 7.1 & 14 & 8.9 & 15 & 4 & 3 & 5 & 3 & 6.3 & 2.0 & 21.1 & 4.6 & 9.3 \\
\hline $\mathrm{Cl}^{-}$ & 7.5 & 160 & 43.7 & 23.2 & 21.2 & 130 & 72 & 330 & 160 & 330 & 236 & 111 & 211 & 106 & 161 & 80 & 260 & 108 & 255 \\
\hline $\mathrm{NO}_{3}-$ & 5.6 & 460 & 188 & 54 & 53 & 460 & 234 & - & - & -- & 750 & 354 & 522 & 248 & 482 & 247 & 672 & 339 & 660 \\
\hline $\mathrm{SO}_{4}{ }^{2-}$ & 22 & 343 & 530 & 247 & 267 & 820 & 420 & 1300 & 660 & 1300 & 552 & 282 & 1260 & 556 & 588 & 298 & 976 & 489 & 966 \\
\hline $\mathrm{SHO}_{2}$ & 61 & 95.1 & 142 & 214 & 231 & 414 & 219 & 408 & 205 & 421 & 451 & 210 & 488 & 267 & 458 & 276 & 406 & 216 & 240 \\
\hline $\mathrm{pH}\left(20^{\circ} \mathrm{C}\right)$ & 8.5 & 8.4 & 8.5 & 9.0 & & & & & & 8.4 & 9.0 & & 8.9 & & 9.3 & & 9.3 & & \\
\hline $\mathrm{pH}\left(100^{\circ} \mathrm{C}\right)$ & & & 7.6 & 8.5 & 8.6 & & & & & 7.7 & 8.3 & & 8.3 & & 8.5 & & 8.6 & & \\
\hline
\end{tabular}

LEGEND

N.D. - Not determined

a) J-13 groundwater

- Reaction with bofling distilled water for one month and filtered.

- Indicates sample number for easy 1dentification.

Reaction with fresh bolling distilled water for one more month after (b).

Subsequent seven-week lnteraction with fresh distilled water after (d).

- Subsequent four-month and one-week Interaction with fresh d1stilled water after (d).

- Undiluted and

j) - Solution cooled to room temperature in contact with tuff for three days and subsequently filtered. 
cooled to room temperature and it was maintained in contact with the tuff for three days. The solution was filtered and analyzed. The analysis is shown in Table 19 (Sample No. 22). Comparing it with the undiluted and filtered solution (Sample No. 21), it is seen that the concentrations of various species in both solutions are the same, within experimental error, except for $\mathrm{SiO}_{2}$ which decreased by $40 \%$ from the original concentration. Therefore, part of the $\mathrm{SiO}_{2}$ in the solution may have been removed as particulate matter.

To make a detailed comparison of the compositions of the solutions after the 3-, 6- and 12-month tests, the undiluted and filtered solution concentrations are retabulated in Table 20. This shows that the concentrations of the species in solution at the conclusion of all three tests increased many-fold compared to the starting solutions. However, as the tests progress from three-months to one-year, there are no large changes in the concentrations of the ionic species except for $\mathrm{SO}_{4}{ }^{2-}$ and $\mathrm{Ca}^{2+}$ ions, both of which decrease with time. This could be attributed to the precipitation of $\mathrm{CaSO}_{4}$ which may have deposited on the surfaces of the specimens or the tuff. The salt film on the surface of a Type 304L specimen in a 6-month test in $\mathrm{J}-13$ water was examined using an EDAX technique to determine its composition. Qualitatively, silicon and aluminum were identified as the major elements, with calcium, chloride and sulfur present in smaller concentrations. This is consistent with precipitation of $\mathrm{CaSO}_{4}$ from the solution. Table 20 also shows that the $\mathrm{pH}$ increases from 8.4 in the 3-month tests to about 9.3 in the one-year tests. An earlier investigation by one of the authors (Abraham, T., 1981) showed that the stability region of $\mathrm{CaSO}_{4}$ increases with increasing $\mathrm{pH}$, as seen in this investigation.

Figures 45 and 46 show changes in chemical composition of J-13 and tentimes concentrated $\mathrm{J}-13$ solutions as a function of time. Since only three data points are available for each of the species, the shapes of the curves are tentative. However, most ionic concentrations seem to approach stable values after about 6 months.

Oxygen consumption in the test vessel occurs during the tests, as explained in Section 4.5. The ratio of $\mathrm{O}_{2}$ to $\mathrm{N}_{2}$ in air above the boiling test solution was lower than laboratory air. Therefore, the oxygen is being consumed either by metal corrosion or some form of interaction with tuff. The concentration of dissolved oxygen in $\mathrm{J}-13$ and $10 \mathrm{x} J-13$ solution was measured to be 2.8 and $2.7 \mathrm{ppm}$, respectively. This is lower than the equilibrium solubility of $\mathrm{O}_{2}$ (from air) in boiling water, which is $5.25 \mathrm{ppm}$. The lower oxygen concentration in the test solution could be attributed to different water chemistry than pure water or lower partial pressure $\mathrm{O}_{2}$ in the gas above the boiling test solutions. These measurements confirm that there is oxygen in the test environment which is also anticipated in the repository environment. 
Table 20 Chemical composition of test solutions at the end of corrosion tests ( $\mu \mathrm{g} / \mathrm{mL})$ (undiluted and filtered solution).

\begin{tabular}{|c|c|c|c|c|c|c|c|}
\hline & \multirow{2}{*}{$\begin{array}{l}\text { Reference } \\
\mathrm{J}-13 \\
\text { Groundwater }\end{array}$} & \multicolumn{3}{|c|}{ Synthetic J-13 Water } & \multicolumn{3}{|c|}{ 10-Times. Conc. J-13 Water } \\
\hline & & $\begin{array}{c}\text { 3-Month } \\
\text { Test }\end{array}$ & $\begin{array}{c}\text { 6-Month } \\
\text { Test }\end{array}$ & $\begin{array}{c}\text { 1-Year } \\
\text { Test }\end{array}$ & $\begin{array}{c}\text { 3-Month } \\
\text { Test }\end{array}$ & $\begin{array}{c}\text { 6-Month } \\
\text { Test }\end{array}$ & $\begin{array}{c}\text { 1-Year } \\
\text { Test }\end{array}$ \\
\hline $\mathrm{Na}^{+}$ & 45 & N.D.* & 464 & 510 & 867 & 738 & 908 \\
\hline $\mathrm{K}^{+}$ & 4.9 & 238 & 244 & 106 & 244 & 214 & 139 \\
\hline $\mathrm{Ca}^{2+}$ & 14 & 308 & 161 & 104 & 301 & 164 & 129 \\
\hline $\mathrm{Sn}^{2+}$ & N.D. & 3.4 & 0.4 & 1.0 & 4.4 & 0.5 & 1.2 \\
\hline $\mathrm{F}^{-}$ & 2.2 & 12.1 & 4 & 6.31 & 14 & 5 & 21.1 \\
\hline $\mathrm{Cl}^{-}$ & $7 \cdot 5$ & 130 & 236 & 161 & 330 & 211 & 260 \\
\hline $\mathrm{NO}_{3}{ }^{-}$ & 5.6 & 460 & 750 & 482 & - & 522 & 672 \\
\hline $\mathrm{SO}_{4}{ }^{2-}$ & 22 & 820 & 552 & 588 & 1300 & 1260 & 976 \\
\hline $\mathrm{SiO}_{2}$ & 61 & 414 & 451 & 458 & 408 & 488 & 406 \\
\hline $\begin{array}{l}\mathrm{pH} \text { at room } \\
\text { temperature }\end{array}$ & 8.5 & 8.4 & 9.0 & 9.3 & 8.4 & 8.9 & 9.3 \\
\hline D. $=\mathrm{NC}$ & & & & & & & \\
\hline
\end{tabular}




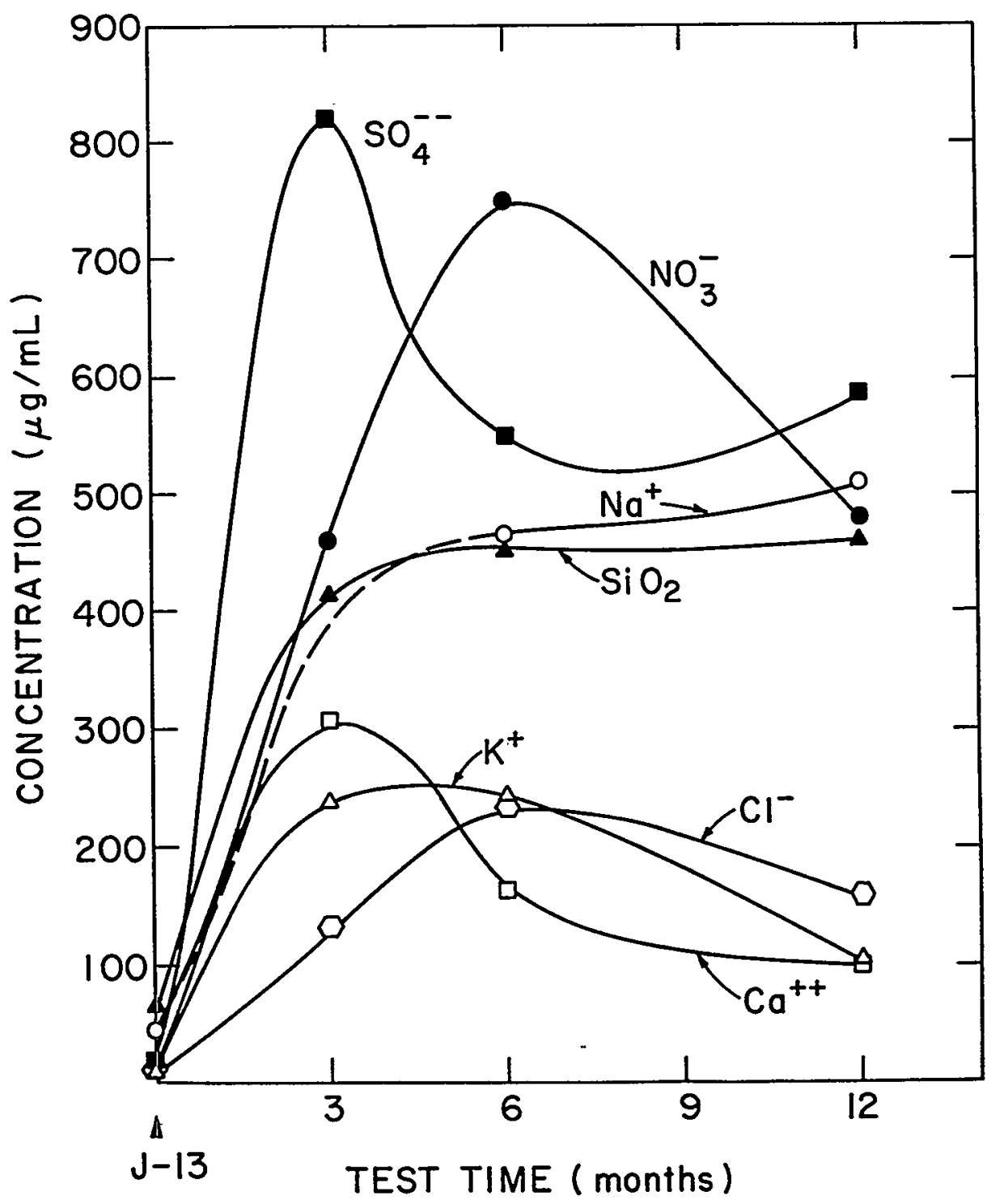

Figure 45 Concentration changes in J-13 water during reaction with crushed tuff at $100^{\circ} \mathrm{C}$. 


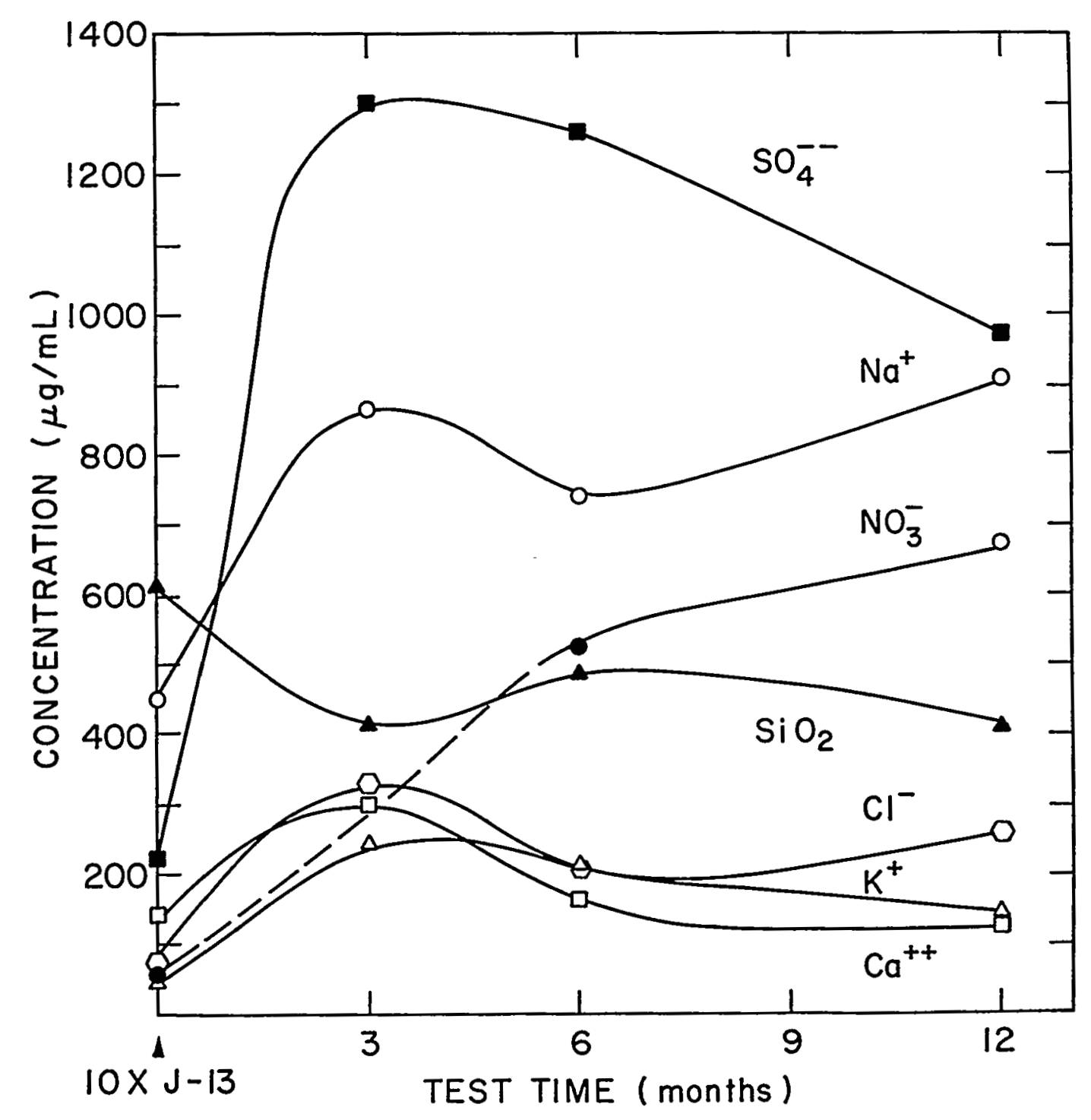

Figure 46 Concentration changes in $10 \times J-13$ water during reaction with crushed tuff at $100^{\circ} \mathrm{C}$. 


\section{DISCUSSION AND CONCLUSIONS}

In this study a total of 288 C-ring specimens was exposed to either aqueous or steam/air environments for periods up to one year. No specimen showed evidence of macroscopic cracks, either at the V-notch or in regions on the sample surface. Tables 15 through 18 summarize the results of detailed metallographic studies on a range of samples encompassing different test enviroments, different heat treatments, and different test times. The objective was to establish if microcracking was present and, if so, to determine the important factors that govern its initiation. Where possible the type of crack (intergranular, transgranular, or mixed) is specified. This, however, proved to be very difficult to determine in most cases since the "sensitizing" heat treatment given to half the samples may not have led to significant precipitation of chromium carbide at the boundary. This is because the Types 304L and 316L stainless steel heats used in this study were exceptionally low in carbon (0.016 wt. percent in each case). Thus, it was difficult to metallographically etch the boundaries and to determine whether the microcracks follow these paths. The Type 321 stainless steel and Incoloy 825 were also low in carbon ( 0.028 and $0.02 \mathrm{wt}$. percent, respectively) which, coupled with their tendancy to form intragranular titanium carbides rather than intergranular chromium carbide, would also minimize sensitization and grain boundary etching.

From an examination of Tables 15 through 18 the following general conclusions may be drawn:

- Both sensitized and non-sensitized specimens may suffer from microcracking and intergranular attack.

- Microcracking occurs in both aqueous as well as air/steam environments. The environments are equally aggressive based on similar numbers of cracked specimens in each environment. Microcracks appear at notches and in regions away from notches. There is no clear effect of stress on crack depth.

- There does not appear to be a significant difference in the degree of cracking in $\mathrm{J}-13$ and $10 \mathrm{xJ}-13$ solutions. Possibly, this is because the two solutions quickly become similar due to interactions with the tuff.

- The crack paths are usually difficult to determine but some are definitely intergranular and some are transgranular. Branched cracks are often observed.

- Type 316L stainless steel specimens used in this study are more susceptible to cracking than Type 304L. This is possibly due to the presence of very small cracks which could be present in some Type 316L specimens prior to testing. These cracks were probably formed at the mill and in some specimens were not removed by surface abrasion with silicon carbide paper during the C-ring fabrication process. Nevertheless, some cracks in Type 316L, which were found at the notched region, were clearly formed during the test period. 
- More limited examination was carried out on Type 321 stainless steel and Incoloy 825 specimens, but they also are susceptible to microcracking. They are, however, probably superior to Types 304L and 316L stainless steel.

Based on the above observations it must be concluded that Types $304 \mathrm{~L}$, $316 \mathrm{~L}$, and 321 stainless steels are susceptible to cracking (either intergranular corrosion, intergranular stress corrosion cracking, or transgranular stress corrosion cracking) in aqueous environments at $100^{\circ} \mathrm{C}$ containing significant levels of chloride ion, oxygen, and other ionic species. Cracking also occurs at the same frequency in the steam/air phase above these boiling solutions. Incoloy 825 appears to be significantly more resistant to cracking under similar conditions.

\section{SUMMARY}

The relatively short test times, low test temperature, and low-carboncontent materials used in this study would be expected to inhibit crack initiation in chloride/oxygen environments. The fact that cracks were detected for a wide range of test conditions casts serious doubt on the integrity of these austenitic alloys. In a tuff repository, very long term exposure to gamma radiolysis effects, chloride-concentration mechanisms, and temperatures up to approximately $300^{\circ} \mathrm{C}$, can only be expected to exacerbate the widelyrecognized susceptibility of austenitic stainless steels to cracking in chloride/oxygen/water(steam) environments. 


\section{REFERENCES}

Abraham, T., "A Thermodynamic Study of the Aqueous System, Ca-S- $\mathrm{H}_{2} \mathrm{O}$, " Doctoral Thesis, Columbia University, New York, 1981.

Birchon, D. and G.G. Booth, "Stress Corrosion Cracking of Some Austenitic Stainless Steels as Affected by Surface Treatment and Water Composition," in Proceedings of 2nd International Congress on Metallic Corrosion, NACE, p. 33, 1964.

C00-1319-82, "A Study of the Mechanisms of Stress Corrosion Cracking in the Iron-N1cke1-Chromium Alloy System," R.W. Staehle, Ohio State Univ., 1970.

Fujiwara, K., T. Fukuzuka, K. Shimogori and H. Tomari, "Effect of Chemical Composition on the IGSCC Susceptibility of Austenitic Stainless Steels in High Temperature Deionized Water," in Predictive Methods for Assessing Corrosion Damage to BWR Piping and PWR Steam Generators, H. Okada and R. Staehle, Eds., NACE, p. 187, 1982 .

Furuya, T., and others, "Influence of Gamma-Ray Irradiation on Stress Corrosion Cracking of Austenitic Stainless Steels," in Fuel Reprocessing and Waste Management, Vol. 1, ANS, 1984, p. 1-493.

JAERI-M-82-145, "Progress Report on Safety Research of High Level Waste Management for the Period April 1981 to March 1982," Tashiro, S., 1983.

Jain, H. and P. Soo, "Testing for Stress Corrosion Cracking of High Level Waste Container Materials in Tuff Repository Environments," BNL Status Report to the NRC Office of Nuclear Materials Safety and Safeguards, May 1985.

Kowaka, M., H. Nagano, K. Yoshikawa, T. Kobayashi, M. Miura, Y. Sawaragi, K. Ohta and S. Nagata, "Development of Alternative Materials for BWR Piping," in Predictive Methods for Assessing Corrosion Damage to BWR Piping and PWR Steam Generators," H. Okada and R. Staehle, Eds., NACE, p. 193, 1982.

McCright, R.D., R.A. Van Konynenburg and I.B. Ballou, "Corrosion Test Plan to Guide Canister Material Selection and Design for a Tuff Repository," in Scientific Basis for Nuclear Waste Management, VII, G.L. McVay, Ed., North Holland, New York, p. 309, 1984.

NUREG/CR-3091, Vol. 6, "Review of Waste Package Verification Tests - Biannual Report," P. Soo, Ed., Brookhaven National Laboratory, 1985.

Russe11, E.W. et al., "Selection of Barrier Metals for a Waste Package in Tuff," in Scientific Basis for Nuclear Waste Management, VII, G.L. McVay, Ed., North Holland, New York, p. 763, 1984. Also published as LLNL report UCRL-89404, Rev. 1, 1983.

Staehle, R.W., J.J. Royuela, T.L. Raredon, E. Serrate, C.R. Moyin and R.V. Farrar, "Effect of Alloy Composition on Stress Corrosion Cracking of Fe-Cr-Ni Base Alloys," Corrosion-NACE, Vol. 26, No. 11, p. 451, November 1970. 
UCRL-53574, "Reaction of the Topopah Spring Tuff With J-13 Water at $120^{\circ} \mathrm{C}$, V.M. Oversby, Lawrence Livermore National Laboratory, 1984.

UCRL-89988, "Selection of Candidate Canister Materials for High-Level Nuclear Waste Containment in a Tuff Repository," McCright, R.D., H. Weiss, M.C. Juhas, and R.W. Logan, Lawrence Livermore National Laboratory, 1983.

UCRL-91804, "Behavior of Stressed and Unstressed 304L Specimens in Tuff Repository Environmental Conditions, M.C. Juhas, R.D. McCright and R.E. Garrison, Lawrence Livermore National Laboratory, 1984. Also published in Corrosion/85, paper 117 , NACE, 1985.

Warren, D., "Chloride-Bearing Cooling Water and the Stress Corrosion Cracking of Iron-Nickel-Chromium Alloys," in Proceedings of the 15th Industrial Waste Conference, Pub. by Purdue Univ., p. 420, 1960.

Williams, W.L., "Chloride and Caustic Stress Corrison of Austenitic Stainless Steel in Hot Water and Steam," Corrosion, 13, 539A, 1957. 


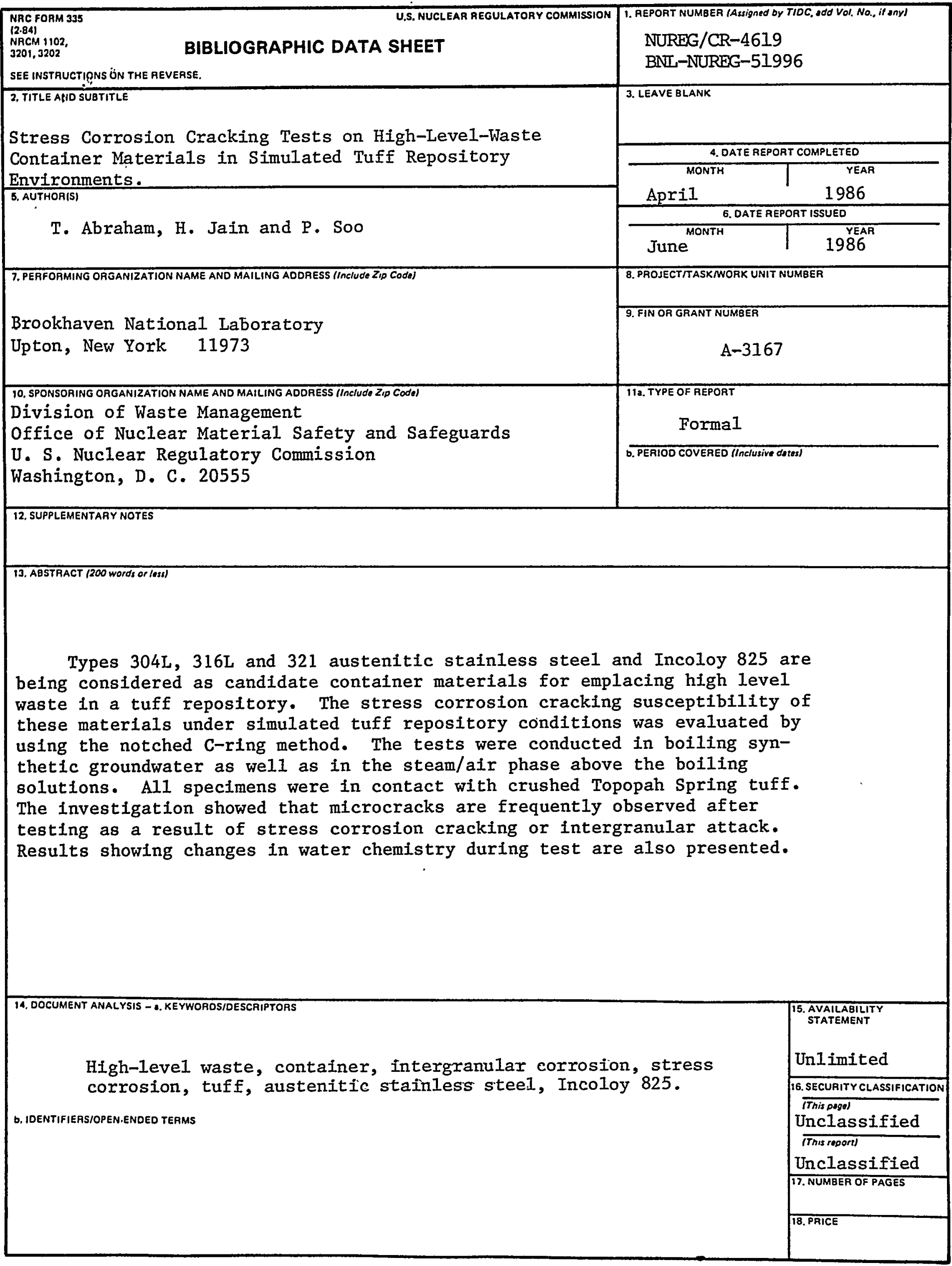

